This document was prepared in conjunction with work accomplished under Contract No. DE-AC09-96SR18500 with the U. S. Department of Energy.

\title{
DISCLAIMER
}

This report was prepared as an account of work sponsored by an agency of the United States Government. Neither the United States Government nor any agency thereof, nor any of their employees, nor any of their contractors, subcontractors or their employees, makes any warranty, express or implied, or assumes any legal liability or responsibility for the accuracy, completeness, or any third party's use or the results of such use of any information, apparatus, product, or process disclosed, or represents that its use would not infringe privately owned rights. Reference herein to any specific commercial product, process, or service by trade name, trademark, manufacturer, or otherwise, does not necessarily constitute or imply its endorsement, recommendation, or favoring by the United States Government or any agency thereof or its contractors or subcontractors. The views and opinions of authors expressed herein do not necessarily state or reflect those of the United States Government or any agency thereof. 
WSRC-TR-2005-00169, REVISION 0

SRNL-RPP-2005-00023, REVISION 0

\section{EVALUATION OF WET CHEMICAL ICP-AES ELEMENTAL ANALYSIS METHODS USING SIMULATED HANFORD WASTE SAMPLES-PHASE I INTERIM REPORT (U)}

\section{ANALYTICAL DEVELOPMENT SECTION STATISTICAL CONSULTING SECTION}

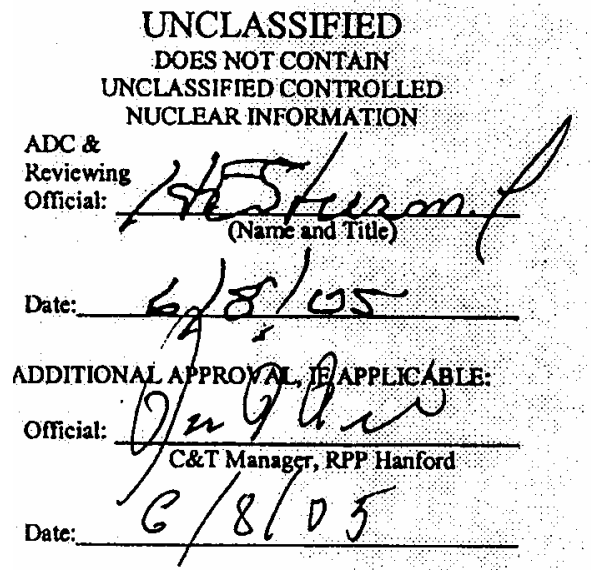

APRIL 2005

Westinghouse Savannah River Company Savannah River Site Aiken, SC 29808

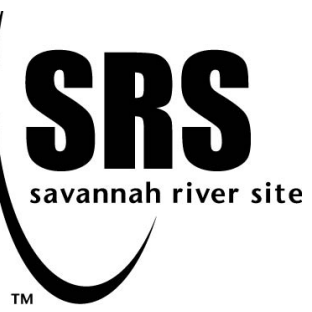


WSRC-TR-2005-00169, REVISION 0

SRNL-RPP-2005-00023, REVISION 0

DISCLAIMER

This report was prepared for the United States Department of Energy under Contract No. DE-AC09-96SR18500 and is an account of work performed under that contract. Neither the United States Department of Energy, nor WSRC, nor any of their employees makes any warranty, expressed or implied, or assumes any legal liability or responsibility for accuracy, completeness, or usefulness, of any information, apparatus, or product or process disclosed herein or represents that its use will not infringe privately owned rights. Reference herein to any specific commercial product, process, or service by trade name, trademark, name, manufacturer or otherwise does not necessarily constitute or imply endorsement, recommendation, or favoring of same by Westinghouse Savannah River Company or by the United States Government or any agency thereof. The views and opinions of the authors expressed herein do not necessarily state or reflect those of the United States Government or any agency thereof.

Printed in the United States of America

Prepared For

U.S. Department of Energy 
Key Words:

Elemental Analysis

Process Control

Retention:

Permanent

Key WTP C\&T References:

Statement of Work: "WSRC-SRNL NTP

Wet Chemistry \& Laser Ablation Testing," CCN 091850, August 2004.

Test Plan: WSRC-TR-2004-00447

\title{
EVALUATION OF WET CHEMICAL ICP-AES ELEMENTAL ANALYSIS METHODS USING SIMULATED HANFORD WASTE SAMPLES-PHASE I INTERIM REPORT (U)
}

\author{
Charles J. Coleman, SRNL \\ Thomas B. Edwards, SRNL
}

APRIL 2005

Westinghouse Savannah River Company Savannah River Site Aiken, SC 29808

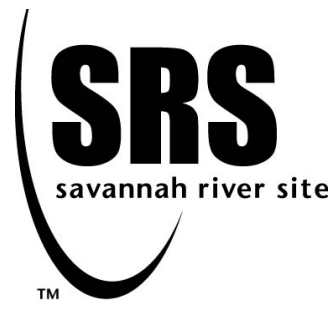




\section{REVIEWS AND APPROVALS}
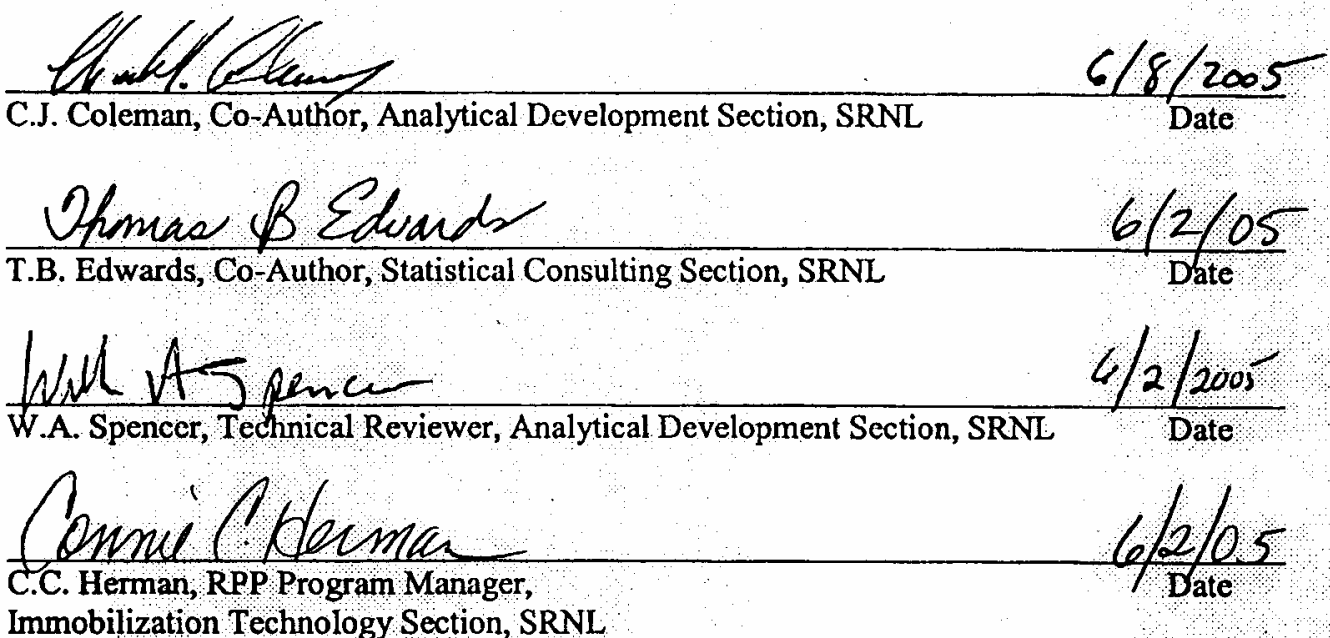
Immobilization Technology Section, SRNL

\begin{tabular}{|c|c|}
\hline Rera L $_{3}$ & $6 / 61.5$ \\
\hline $\begin{array}{l}\text { R.E. Edwards, Manager, RPP Project, } \\
\text { Waste Treatment Technology Section, SRNL }\end{array}$ & Date \\
\hline RD/mssne for 4 kn & $6 / 8105$ \\
\hline Aruna Arakali, C\&T, WTP-RPP & Date \\
\hline
\end{tabular}




\section{TABLE OF CONTENTS}

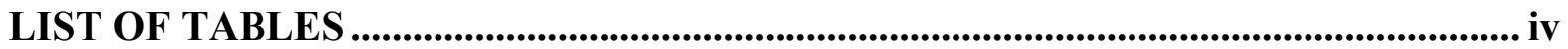

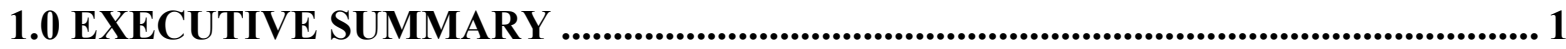

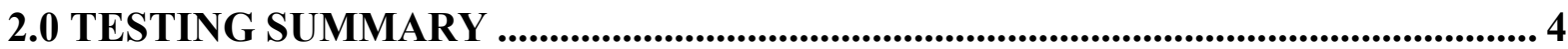

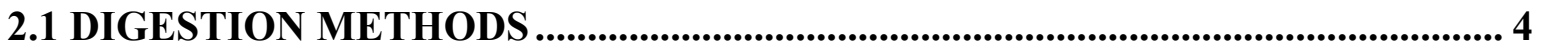

2.1.1 HLW-2A - AY-102/C-106 Simulant............................................................................... 4

2.1.2 HLW-2A - AZ-101 Simulant ........................................................................................ 4

2.1.3 HLW-2B - AY-102/C-106 simulant + glass formers ................................................ 5

2.1.4 Use of Matrix Spikes ......................................................................................................... 8

2.1.5 Use of Laboratory Control Standard ........................................................................ 9

2.1.6 ICP-AES Analysis of Solutions ................................................................................. 9

2.1.7 Measurement of Wt. \% Oxides.......................................................................... 9

2.1.8 Statistical Analysis............................................................................................................. 9

2.2 OBJECTIVES................................................................................................................. 10

2.3 TEST EXCEPTIONS .......................................................................................................... 11

2.4 RESULTS AND PERFORMANCE AGAINST SUCCESS OBJECTIVES ........... 12

2.5 QUALITY REQUIREMENTS.................................................................................... 12

2.6 C\&T TEST CONDITIONS ........................................................................................ 12

2.7 SIMULANT USE ............................................................................................................ 13

2.8 DISCREPANCIES AND FOLLOW-ON TESTS ........................................................ 13

3.0 DISCUSSION ......................................................................................................................... 14

3.1 METHOD DEVELOPMENT GOALS - RATIONALE FOR METHODS

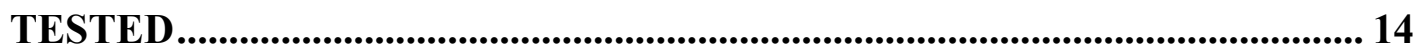

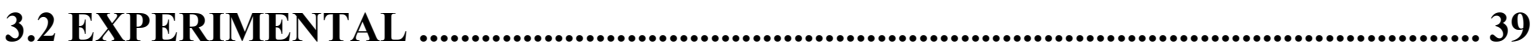

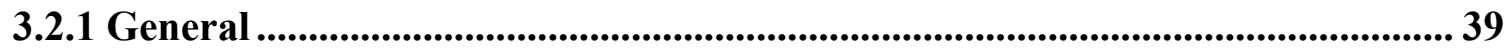

3.2.2 Alkali Fusion Digestion Methods ................................................................................. 39

3.2.3 Mixed-Acid Digestion Methods........................................................................... 41

3.2.4 ICP-AES Experimental.................................................................................................... 45

3.2.5 Measurement of Wt. \% Oxide of Simulants ........................................................ 46

3.2.6 Use of Matrix Spikes ..................................................................................................... 47

3.2.7 Use of Laboratory Control Standard (LCS) ............................................................ 49

3.2.8 Sample Tracking ………............................................................................................... 51

3.2.9 Statistical Analysis.............................................................................................. 51

4.0 FUTURE WORK ................................................................................................... 52

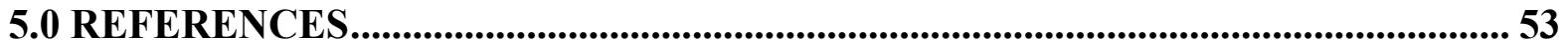




\section{LIST OF TABLES}

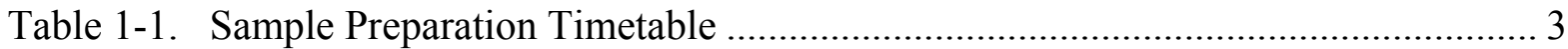

Table 1-2. ICP-AES Laboratory Timetable …………….................................................. 3

Table 2-1. Summary Table of Digestion Methods Tested in Phase I ................................... 6

Table 3-1. Elemental Analysis of AY-102/C-106 Simulant - WTP Sample Type: HLW-2A -

Digestion Method: Sodium Peroxide-Sodium Hydroxide Fusion in $\mathrm{Zr}$ crucibles ........... 21

Table 3-2. Elemental Analysis of AY-102/C-106 Simulant - WTP Sample Type: HLW-2A -

Digestion Method: Sodium Peroxide Fusion in Ni crucibles......................................... 22

Table 3-3. Elemental Analysis of AZ-101 Simulant - Type of WTP Waste: HLW-2A -

Digestion Method: Sodium Peroxide Fusion in Ni Crucibles......................................... 23

Table 3-4. Elemental Analysis of AY-102/C-106 Melter Feed as Dried Slurry - WTP

Sample Type: HLW-2B - Sample Digestion Method: Sodium Peroxide Fusion in Ni Crucibles

Table 3-5. Elemental Analysis of AY-102/C-106 Melter Feed Vitrified into Glass - WTP

Sample Type: HLW-2B - Sample Digestion Method: Sodium Peroxide Fusion in Ni

Crucibles 25

Table 3-6. Elemental Analysis of AY-102/C-106 Simulant - WTP Sample Type: HLW-2A -

Digestion Method: Cesium Hydroxide in Zr Crucible.................................................... 26

Table 3-7. Elemental Analysis of AY-102/C-106 Simulant - WTP Sample Type: HLW-2A -

Digestion Method: $\mathrm{CsOH}$ in Nickel Crucible ………….......................................... 27

Table 3-8. Elemental Analysis of AY-102/C-106 Simulant - WTP Sample Type: HLW-2A

- Digestion Method: $\mathrm{CsOH} / \mathrm{Cs}_{2} \mathrm{CO}_{3}$ Fusion in Pt crucibles ........................................ 28

Table 3-9. Elemental Analysis of AY-102/C-106 Melter Feed as Dried Slurry - WTP

Sample Type: HLW-2B - Digestion Method: Cesium Carbonate Fusion in Pt Crucibles

Table 3-10. Elemental Analysis of AY-102/C-106 Melter Feed Vitrified into Glass - WTP Sample Type: HLW-2B - Digestion Method: Cesium Carbonate Fusion in Pt Crucibles

Table 3-11. Elemental Analysis of AY-102/C-106 Simulant - WTP Sample Type: HLW-2A

- Digestion Method: KOH Fusion in Zr crucibles ....................................................... 31

Table 3-12. Elemental Analysis of AZ-101 Simulant - Type of WTP Waste: HLW-2A -

Digestion Method: KOH Fusion in Zirconium Crucibles............................................... 32

Table 3-13. Elemental Analysis of AY-102/C-106 Melter Feed Vitrified into Glass - WTP

Sample Type: HLW-2B - Sample Digestion Method: Potassium Carbonate Fusion in Pt

Crucibles

Table 3-14. Elemental Analysis of AY-102/C-106 Simulant - Type of WTP Waste: HLW-

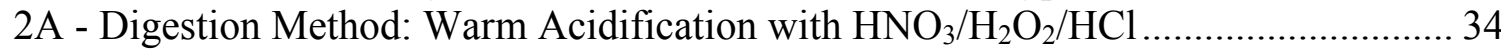

Table 3-15. Elemental Analysis of AZ-101 Simulant - Digestion Method: Warm

Acidification with $\mathrm{HNO}_{3} / \mathrm{H}_{2} \mathrm{O}_{2} / \mathrm{HCl}$..................................................................... 35

Table 3-16. Elemental Analysis of AY-102/C-106 Melter Feed - WTP Sample Type: HLW-

2B - Digestion Method: Warm Acidification with $\mathrm{HNO}_{3} / \mathrm{H}_{2} \mathrm{O}_{2} / \mathrm{HCl}$............................ 36

Table 3-17. Elemental Analysis of AY-102/C-106 Simulant - WTP Sample Type:HLW-2A

- Digestion Method: $\mathrm{HF}-\mathrm{HCl}$ with Heating

Table 3-18. Elemental Analysis of AY-102/C-106 Simulant - Type of WTP Waste: HLW-

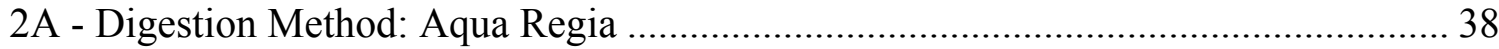


Table 3-19. Procedure for Sodium Peroxide Fusion Method ............................................ 42

Table 3-20. Warm Mixed-Acid Method .............................................................................. 44

Table 3-21. ICP-AES Wavelengths Used for Elemental Determinations ......................... 45

Table 3-22. Wt. \% Oxides Measurements for WTP Simulants ........................................... 46

Table 3-23. Elemental Composition of ARG-1 Reference Glass ...................................... 49 
WSRC-TR-2005-00169, REVISION 0

SRNL-RPP-2005-00023, REVISION 0

This page intentionally left blank.

- vi - 
WSRC-TR-2005-00169, REVISION 0

SRNL-RPP-2005-00023, REVISION 0

\subsection{EXECUTIVE SUMMARY}

The wet chemistry digestion method development for providing process control elemental analyses of the Hanford Tank Waste Treatment and Immobilization Plant (WTP) Melter Feed Preparation Vessel (MFPV) samples is divided into two phases:

Phase I consists of: 1) optimizing digestion methods as a precursor to elemental analyses by ICP-AES techniques; 2) selecting methods with the desired analytical reliability and speed to support the nine-hour or less turnaround time requirement of the WTP; and 3) providing baseline comparison to the laser ablation (LA) sample introduction technique for ICP-AES elemental analyses that is being developed at the Savannah River National Laboratory (SRNL).

Phase II consists of: 1) Time-and-Motion study of the selected methods from Phase I with actual Hanford waste or waste simulants in shielded cell facilities to ensure that the methods can be performed remotely and maintain the desired characteristics; and 2) digestion of glass samples prepared from actual Hanford Waste tank sludge for providing comparative results to the LA Phase II study.

Based on the Phase I testing discussed in this report, a tandem digestion approach consisting of sodium peroxide fusion digestions carried out in nickel crucibles and warm mixed-acid digestions carried out in plastic bottles has been selected for Time-and-Motion study in Phase II. SRNL experience with performing this analytical approach in laboratory hoods indicates that well-trained cell operator teams will be able to perform the tandem digestions in five hours or less. The selected approach will produce two sets of solutions for analysis by ICP-AES techniques. Four hours would then be allocated for performing the ICP-AES analyses and reporting results to meet the nine-hour or less turnaround time requirement.

The tandem digestion approach will need to be performed in two separate shielded analytical cells by two separate cell operator teams in order to achieve the nine-hour or less turnaround time. Because of the simplicity of the warm mixed-acid method, a well-trained cell operator team may in time be able to perform both sets of digestions. However, having separate shielded cells for each of the methods is prudent to avoid overcrowding problems that would impede a minimal turnaround time.

Selection of the tandem digestion approach of using sodium peroxide fusions in nickel crucibles and warm mixed-acid digestions was based on these advantages:

- ICP-AES laboratory dead-time is minimized by obtaining solutions from the warm mixed-acid method within three hours after the samples are transported into the shielded cells. These solutions can be analyzed by ICP-AES as the sodium peroxide fusions are being completed. The two sets of digestions will be naturally staggered as a function of the time required to perform them, resulting in more efficient use of ICP-AES laboratory time than if the two sets of digestions were completed simultaneously (a likely scenario if two different alkali fusion methods were selected). 
- The warm mixed-acid method dissolves $\mathrm{Ni}$ in the sludge and four of the five glassformer/glass-modifier elements (Na, Li, B, Zn). This method may also prove better for $\mathrm{S}$, $\mathrm{U}, \mathrm{Ca}, \mathrm{K}$ and other minor component determinations because of the relatively clean matrix of the acid digestion.

- The warm mixed-acid method produces a low concentration of dissolved solids in the solution aspirated into the ICP-AES. Therefore, this solution is less likely than alkali fusion methods to affect nebulizer performance (through evaporative deposition of dissolved solids at the nebulizer tip) which could result in degradation of ICP-AES performance over time. Any degradation of nebulizer/ICP-AES performance would require lengthy recalibration procedures prior to analysis of the sodium peroxide fusion digestions.

- The sodium peroxide fusion is the most rigorous of the alkali fusion methods. The highly oxidizing sodium peroxide flux is superior to most digestion methods for dissolving refractory elements (Al, Si, Fe, Mn, Zr, Ti, Cr, noble metals, and others) in Hanford waste. This method is also effective for the refractory glass-former materials, $\mathrm{SiO}_{2}$ in particular.

- Both the sodium peroxide fusion and warm mixed-acid method have the potential speed, convenience, and reliability advantages for remote cell operations. The methods have been streamlined to be simple to perform remotely and to minimize tedious, timeconsuming manipulations that may result in analytical errors.

The nine-hour-or-less turnaround time requirement will demand close coordination of the shielded cell sample preparation team and the ICP-AES laboratory team. The timetables in Table 1-1 and Table 1-2 show schedules that would successfully meet the turnaround time requirement. 
Table 1-1. Sample Preparation Timetable Activity

Remove up to 8 samples from rabbit bottles

Sub-sample; weigh sub-samples

Perform warm mixed-acid method; dry

sample for $\mathrm{Na}_{2} \mathrm{O}_{2}$ fusion method

Perform $\mathrm{Na}_{2} \mathrm{O}_{2}$ fusion method

Table 1-2. ICP-AES Laboratory Timetable

\section{Activity}

Calibrate ICP-AES; analyze check standards for mixed-acid digestion

Analyze up to 8 mixed-acid prep solutions

+ standards + blanks

Check calibration; re-calibrate if necessary

Analyze up to 8 fusion prep solutions + standards + blanks

Compile results from both preps and report
Time from Samples Entering Cells (hr.)

0-1

$1-2$

$2-3$

$3-5$

Time from Samples Entering Cells (hr.)

$0-3$

$3-4.5$

4.5-6

6-7.5

$7.5-9$ 
WSRC-TR-2005-00169, REVISION 0

SRNL-RPP-2005-00023, REVISION 0

\subsection{TESTING SUMMARY}

As part of the Phase I program to develop wet chemistry methods to support WTP, tests were performed to help optimize the speed, efficiency, and reliability of digestion methods followed by elemental analysis of solutions by ICP-AES techniques. Digestions and elemental analyses were performed on two High-Level Waste (HLW)-2A simulants, AY102/C-106 and AZ-101, and on one HLW-2B simulant, a mixture of AY-102/C-106 sludge and glass-forming/glass-modifying chemicals. The Analytical Development Section (ADS) of SRNL performed the tests. ADS issued a Task Technical and Quality Assurance Plan [1] based on specifications given in the Statement of Work that was provided by WTP [2] for this testing program. The Statistical Consulting Section of SRNL performed the statistical data analysis.

\subsection{DIGESTION METHODS}

The following digestion methods were tested on the respective sample matrices. Because of the nine-hour or less turnaround time requirement for MFPV samples, emphasis was placed on streamlining methods to reduce turnaround time. C.J. Coleman of ADS performed digestions of simulants in chemical fume hoods.

\subsubsection{HLW-2A - AY-102/C-106 Simulant}

- Sodium peroxide fusions in both $\mathrm{Ni}$ and $\mathrm{Zr}$ crucibles [3]

- Cesium hydroxide fusions in both $\mathrm{Ni}$ and $\mathrm{Zr}$ crucibles [3], [4]

- Mixture of cesium hydroxide/cesium carbonate fusions in Pt crucibles

- Potassium hydroxide fusions in $\mathrm{Zr}$ crucibles [5]

- Hot hydrochloric acid-nitric acid mixture (aqua regia) in a sealed Teflon container [6]

- Hot hydrochloric acid-hydrofluoric acid in a sealed Teflon container [7]

- Mixture of nitric acid, hydrogen peroxide, and hydrochloric acid in a plastic bottle. This mixture was not externally heated but became warm from the chemical decomposition of hydrogen peroxide in strong acid solution, as well as from digestion of the sample.

\subsubsection{HLW-2A - AZ-101 Simulant}

- Sodium peroxide fusion in Ni crucibles [3]

- Potassium hydroxide fusion in $\mathrm{Zr}$ crucibles [5]

- Mixture of nitric acid, hydrogen peroxide, and hydrochloric acid in a plastic bottle. This mixture was not externally heated but became warm from the chemical decomposition of hydrogen peroxide in strong acid solution, as well as from digestion of the sample. 


\subsubsection{HLW-2B - AY-102/C-106 simulant + glass formers}

- Sodium peroxide fusion in Ni crucibles [3]

- Cesium carbonate fusion in Pt crucibles [8]

- Potassium carbonate fusion in Pt crucibles [8]

- Mixture of nitric acid, hydrogen peroxide, and hydrochloric acid in a plastic bottle. This mixture was not externally heated but became warm from the chemical decomposition of hydrogen peroxide in strong acid solution, as well as decomposition of the sample.

Table 2-1 summarizes the dissolution methods and the test conditions for both the alkali fusions and mixed-acid digestions. This table provides a link from the digestion conditions to the ICP-AES elemental analyses of the digestion solutions. 
WSRC-TR-2005-00169, REVISION 0

SRNL-RPP-2005-00023, REVISION 0

Table 2-1. Summary Table of Digestion Methods Tested in Phase I

\begin{tabular}{|c|c|c|c|c|c|c|}
\hline \multicolumn{7}{|c|}{ Alkali Fusion Methods ${ }^{\text {a. }}$} \\
\hline Digestion Method & $\begin{array}{l}\text { Sample } \\
\text { Matrix }\end{array}$ & $\begin{array}{c}\text { Data in } \\
\text { Table }\end{array}$ & $\begin{array}{l}\text { Reagents } \\
\text { Used }\end{array}$ & $\begin{array}{c}\text { Digestion } \\
\text { Vessel }\end{array}$ & $\begin{array}{c}\text { Heating } \\
\text { Time }\end{array}$ & $\begin{array}{c}\text { Heating } \\
\text { Temp. }\end{array}$ \\
\hline $\begin{array}{l}\mathrm{Na}_{2} \mathrm{O}_{2} / \mathrm{NaOH} \\
\text { Reference } 3\end{array}$ & $\begin{array}{l}\text { AY-102/ } \\
\text { C-106 } \\
\text { (as dried } \\
\text { powder) }\end{array}$ & 3.1 .1 & $\begin{array}{l}\mathrm{Na}_{2} \mathrm{O}_{2} / \mathrm{NaOH} \text {-flux } \\
\text { reagent } \\
\mathrm{HNO}_{3} \text {-uptake acid }\end{array}$ & $\mathrm{Zr}$ crucible & $\begin{array}{c}10 \\
\text { minutes }\end{array}$ & $675^{\circ} \mathrm{C}$ \\
\hline $\begin{array}{l}\mathrm{Na}_{2} \mathrm{O}_{2} \\
\text { Reference } 3\end{array}$ & $\begin{array}{l}\text { AY-102/ } \\
\text { C-106 } \\
\text { (as dried } \\
\text { powder) }\end{array}$ & 3.1 .2 & $\begin{array}{l}\mathrm{Na}_{2} \mathrm{O}_{2} \text {-flux reagent } \\
\mathrm{HNO}_{3} \text {-uptake acid }\end{array}$ & Ni crucible & $\begin{array}{c}10 \\
\text { minutes }\end{array}$ & $750{ }^{\circ} \mathrm{C}$ \\
\hline $\begin{array}{l}\mathrm{Na}_{2} \mathrm{O}_{2} \\
\text { Reference } 3 \\
\end{array}$ & $\begin{array}{l}\text { AZ-101 } \\
\text { (as dried } \\
\text { powder) }\end{array}$ & 3.1 .3 & $\begin{array}{l}\mathrm{Na}_{2} \mathrm{O}_{2} \text { - flux reagent } \\
\mathrm{HNO}_{3} \text {-uptake acid }\end{array}$ & Ni crucible & $\begin{array}{c}10 \\
\text { minutes }\end{array}$ & $750^{\circ} \mathrm{C}$ \\
\hline $\begin{array}{l}\mathrm{Na}_{2} \mathrm{O}_{2} \\
\text { Reference } 3\end{array}$ & $\begin{array}{l}\text { AY-102/ } \\
\text { C-106 + } \\
\text { glass } \\
\text { formers } \\
\text { (as dried } \\
\text { powder) }\end{array}$ & 3.1 .4 & $\begin{array}{l}\mathrm{Na}_{2} \mathrm{O}_{2} \text {-flux reagent } \\
\mathrm{HNO}_{3} \text {-uptake acid }\end{array}$ & Ni crucible & $\begin{array}{c}10 \\
\text { minutes }\end{array}$ & $750^{\circ} \mathrm{C}$ \\
\hline $\begin{array}{l}\mathrm{Na}_{2} \mathrm{O}_{2} \\
\text { Reference } 3\end{array}$ & $\begin{array}{l}\text { AY-102/ } \\
\text { C-106 + } \\
\text { glass } \\
\text { formers } \\
\text { (vitrified } \\
\text { into glass } \\
\text { wafers) }\end{array}$ & 3.1 .5 & $\begin{array}{l}\mathrm{Na}_{2} \mathrm{O}_{2} \text {-flux reagent } \\
\mathrm{HNO}_{3} \text {-uptake acid }\end{array}$ & Ni crucible & $\begin{array}{c}10 \\
\text { minutes }\end{array}$ & $750^{\circ} \mathrm{C}$ \\
\hline $\begin{array}{l}\mathrm{CsOH} \\
\text { Reference 3, } 4\end{array}$ & $\begin{array}{l}\text { AY-102/ } \\
\text { C-106 } \\
\text { (as dried } \\
\text { powder) }\end{array}$ & 3.1 .6 & $\begin{array}{l}\text { CsOH-flux reagent } \\
\text { HCl-uptake acid }\end{array}$ & Zr crucible & $\begin{array}{c}10 \\
\text { minutes }\end{array}$ & $675^{\circ} \mathrm{C}$ \\
\hline $\begin{array}{l}\mathrm{CsOH} \\
\text { Reference 3, } 4\end{array}$ & $\begin{array}{l}\text { AY-102/ } \\
\text { C-106 } \\
\text { (as dried } \\
\text { powder) }\end{array}$ & 3.1 .7 & $\begin{array}{l}\text { CsOH-flux reagent } \\
\text { HCl-uptake acid }\end{array}$ & Ni crucible & $\begin{array}{c}10 \\
\text { minutes }\end{array}$ & $675^{\circ} \mathrm{C}$ \\
\hline $\mathrm{Cs}_{2} \mathrm{CO}_{3} / \mathrm{CsOH}$ & $\begin{array}{l}\text { AY-102/ } \\
\text { C-106 } \\
\text { (as dried } \\
\text { powder) }\end{array}$ & 3.1 .8 & $\begin{array}{l}\mathrm{Cs}_{2} \mathrm{CO}_{3} / \mathrm{CsOH} \text {-flux } \\
\text { reagent } \\
\text { HCl-uptake acid }\end{array}$ & Pt crucible & $\begin{array}{c}10 \\
\text { minutes }\end{array}$ & $1000^{\circ} \mathrm{C}$ \\
\hline
\end{tabular}


WSRC-TR-2005-00169, REVISION 0

SRNL-RPP-2005-00023, REVISION 0

Table 2-1. Summary Table of Digestion Methods Tested in Phase I - continued

\begin{tabular}{|c|c|c|c|c|c|c|}
\hline \multicolumn{7}{|c|}{ Alkali Fusion Methods ${ }^{\text {a. }}$ - continued } \\
\hline Digestion Method & $\begin{array}{l}\text { Sample } \\
\text { Matrix }\end{array}$ & $\begin{array}{c}\text { Data in } \\
\text { Table }\end{array}$ & $\begin{array}{l}\text { Reagents } \\
\text { Used }\end{array}$ & $\begin{array}{c}\text { Digestion } \\
\text { Vessel }\end{array}$ & $\begin{array}{l}\text { Heating } \\
\text { Time }\end{array}$ & $\begin{array}{l}\text { Heating } \\
\text { Temp. }\end{array}$ \\
\hline $\begin{array}{l}\mathrm{Cs}_{2} \mathrm{CO}_{3} \\
\text { Reference } 8\end{array}$ & $\begin{array}{l}\text { AY-102/ } \\
\text { C-106 + } \\
\text { glass } \\
\text { formers } \\
\text { (as dried } \\
\text { powder) }\end{array}$ & 3.1 .9 & $\begin{array}{l}\mathrm{Cs}_{2} \mathrm{CO}_{3} \text {-flux } \\
\text { reagent } \\
\mathrm{HNO}_{3} \text {-uptake acid }\end{array}$ & Pt crucible & $\begin{array}{c}10 \\
\text { minutes }\end{array}$ & $1100^{\circ} \mathrm{C}$ \\
\hline $\begin{array}{l}\mathrm{Cs}_{2} \mathrm{CO}_{3} \\
\text { Reference } 8\end{array}$ & $\begin{array}{l}\text { AY-102/ } \\
\text { C-106 + } \\
\text { glass } \\
\text { formers } \\
\text { (vitrified } \\
\text { into glass } \\
\text { wafers) }\end{array}$ & 3.1 .10 & $\begin{array}{l}\mathrm{Cs}_{2} \mathrm{CO}_{3} \text {-flux } \\
\text { reagent } \\
\mathrm{HNO}_{3} \text {-uptake acid }\end{array}$ & Pt crucible & $\begin{array}{c}10 \\
\text { minutes }\end{array}$ & $1100^{\circ} \mathrm{C}$ \\
\hline $\begin{array}{l}\mathrm{KOH} \\
\text { Reference 5, } 15\end{array}$ & $\begin{array}{l}\text { AY-102/ } \\
\text { C-106 } \\
\text { (as dried } \\
\text { powder) }\end{array}$ & 3.1 .11 & $\begin{array}{l}\mathrm{KOH} / \mathrm{KNO}_{3} \text { flux } \\
\text { reagent } \\
\text { HCl-uptake acid }\end{array}$ & $\mathrm{Zr}$ crucible & $\begin{array}{c}10 \\
\text { minutes }\end{array}$ & $675^{\circ} \mathrm{C}$ \\
\hline $\begin{array}{l}\mathrm{KOH} \\
\text { Reference } 5\end{array}$ & $\begin{array}{l}\text { AZ-101 } \\
\text { (as dried } \\
\text { powder) }\end{array}$ & 3.1 .12 & $\begin{array}{l}\mathrm{KOH} / \mathrm{KNO}_{3} \text { flux } \\
\text { reagent } \\
\text { HCl-uptake acid }\end{array}$ & Zr crucible & $\begin{array}{c}10 \\
\text { minutes }\end{array}$ & $675^{\circ} \mathrm{C}$ \\
\hline $\begin{array}{l}\mathrm{K}_{2} \mathrm{CO}_{3} \\
\text { Reference } 7\end{array}$ & $\begin{array}{l}\text { AY-102/ } \\
\text { C-106 + } \\
\text { glass } \\
\text { formers } \\
\text { (vitrified } \\
\text { into glass } \\
\text { wafers) }\end{array}$ & 3.1 .13 & $\begin{array}{l}\mathrm{K}_{2} \mathrm{CO}_{3} \text {-flux reagent } \\
\mathrm{HNO}_{3} \text {-uptake acid }\end{array}$ & Pt crucible & $\begin{array}{c}10 \\
\text { minutes }\end{array}$ & $1100^{\circ} \mathrm{C}$ \\
\hline
\end{tabular}


WSRC-TR-2005-00169, REVISION 0

SRNL-RPP-2005-00023, REVISION 0

Table 2-1. Summary Table of Digestion Methods Tested in Phase I - continued

\begin{tabular}{|c|c|c|c|c|c|c|}
\hline \multicolumn{7}{|c|}{ Mixed Acid Methods ${ }^{\text {a }}$} \\
\hline Digestion Method & $\begin{array}{l}\text { Sample } \\
\text { Matrix }\end{array}$ & $\begin{array}{c}\text { Data in } \\
\text { Table }\end{array}$ & $\begin{array}{c}\text { Reagents } \\
\text { Used }\end{array}$ & $\begin{array}{c}\text { Digestion } \\
\text { Vessel }\end{array}$ & $\begin{array}{c}\text { Heating } \\
\text { Time }\end{array}$ & $\begin{array}{c}\text { Heating } \\
\text { Temp. }\end{array}$ \\
\hline $\begin{array}{l}\text { Warm Acidification } \\
\text { with } \\
\mathrm{HNO}_{3} / \mathrm{H}_{2} \mathrm{O}_{2} / \mathrm{HCl}\end{array}$ & $\begin{array}{l}\text { AZ-101 } \\
\text { (as slurry) }\end{array}$ & 3.1 .15 & $\mathrm{HNO}_{3} / \mathrm{H}_{2} \mathrm{O}_{2} / \mathrm{HCl}$ & Plastic bottle & $\begin{array}{c}\sim 10 \\
\text { minutes }\end{array}$ & $\sim 80^{\circ} \mathrm{C}$ \\
\hline $\begin{array}{l}\text { Warm Acidification } \\
\text { with } \\
\mathrm{HNO}_{3} / \mathrm{H}_{2} \mathrm{O}_{2} / \mathrm{HCl}\end{array}$ & $\begin{array}{l}\text { AY-102/ } \\
\text { C-106 + } \\
\text { glass } \\
\text { formers } \\
\text { (as slurry) }\end{array}$ & 3.1 .16 & $\mathrm{HNO}_{3} / \mathrm{H}_{2} \mathrm{O}_{2} / \mathrm{HCl}$ & Plastic bottle & $\begin{array}{c}\sim 10 \\
\text { minutes }\end{array}$ & $\sim 80^{\circ} \mathrm{C}$ \\
\hline $\begin{array}{l}\text { HF-HCl with } \\
\text { external heating } \\
\text { Reference } 7\end{array}$ & $\begin{array}{l}\text { AY-102/ } \\
\text { C-106 } \\
\text { (as slurry) }\end{array}$ & 3.1 .17 & $\mathrm{HF}-\mathrm{HCl}$ & $\begin{array}{l}\text { Pressurized } \\
\text { Teflon } \\
\text { Vessel }\end{array}$ & $\begin{array}{c}45 \\
\text { minutes }\end{array}$ & $115^{\circ} \mathrm{C}$ \\
\hline $\begin{array}{l}\text { Aqua Regia with } \\
\text { external heating } \\
\text { Reference } 6\end{array}$ & $\begin{array}{l}\text { AY-102/ } \\
\text { C-106 } \\
\text { (as slurry) }\end{array}$ & 3.1 .18 & $\begin{array}{l}\mathrm{HCl}-\mathrm{HNO}_{3} \\
\text { (3:1 ratio-aqua } \\
\text { regia) }\end{array}$ & $\begin{array}{l}\text { Pressurized } \\
\text { Teflon } \\
\text { Vessel }\end{array}$ & $\begin{array}{c}45 \\
\text { minutes }\end{array}$ & $115^{\circ} \mathrm{C}$ \\
\hline
\end{tabular}

a. Sample weights were typically 1.5-2.0 grams of slurry. For alkali fusions, an approximate 10:1 ratio of alkali flux reagent to dry powder or glass sample was used. Initial dilution volumes were typically $500 \mathrm{~mL}$ or 525

$\mathrm{mL}$. A 5-fold serial dilution with deionized water was made prior to ICP-AES analysis of the solutions.

\subsubsection{Use of Matrix Spikes}

Two different protocols for matrix spikes were used in the experiments. For approximately $50 \%$ of the digestions, a matrix spike solution consisting of a mixture of $\mathrm{Ag}, \mathrm{Sb}, \mathrm{Cd}, \mathrm{Th}, \mathrm{S}$, $\mathrm{Tl}$, and $\mathrm{U}$ were added after the digestions were performed (the spike was performed just prior to the ICP-AES elemental analysis). This protocol was chosen because none of these 7 elements are found in the Analytical Reference Glass-1 (ARG-1) [9] used as the Laboratory Control Standard (see Table 3-23 for elemental composition of ARG-1 glass standard). After the ICP-AES responses to these elements were measured, subsequent matrix spikes consisted of adding a solution of $\mathrm{Y}$ to the slurry before the digestion step. For both protocols, the ICPAES analysis was used to measure the spike recovery percentage. However, the percent spike recovery was not used to adjust the reported values for the other analytes since use of soluble spike elements is not a technically defensible method to measure the accuracy of digestions/ICP-AES analysis of solid materials. 


\subsubsection{Use of Laboratory Control Standard}

The ARG-1 glass standard was digested and analyzed in duplicate concurrently with the HLW-2A and HLW-2B matrices. The measured value of each element in this glass was compared with the average value as reported by Corning Engineering Laboratory Services (CELS) [9] (see Table 3-23 for elemental composition of ARG-1 glass standard) and the percent difference and the sign of the difference (either positive or negative) was noted. However, the relative percent differences in the SRNL measured values versus the CELS values were not used to adjust the reported values. One reason for this is that the glass standard is not in the same form as the slurry samples. Even if slurry standards were available, the use of bias corrections based on elemental analysis of the standards is not a common practice unless it can be shown categorically that the bias in the standard analysis also occurs in the sample analysis.

\subsubsection{ICP-AES Analysis of Solutions}

Solutions in Phase I tests were analyzed with the ADS ICP-AES spectrophotometer contained in a hood for radioactive samples even though the samples were non-radioactive, with the knowledge that this ICP-AES spectrophotometer would be required for the radiological samples generated in the Phase II tests. ADS QA/QC procedures [10] were used in the ICP-AES determinations. L.L. Farrow performed the ICP-AES determinations with technical oversight from J.C. Hart and spectroscopic analysis assistance from F.M. Pennebaker, all of ADS. Analytical line wavelengths used for ICP-AES analysis of the solutions are listed in Table 3-21.

\subsubsection{Measurement of Wt. \% Oxides}

The three simulants (AY-102/C-106, AZ-101, and AY-102/C-106 plus glass-formers/glassmodifiers) were analyzed for wt. \% oxide content by first evaporating the free water at $200{ }^{\circ} \mathrm{C}$ in a drying oven followed by heating the samples in platinum crucibles in a muffle furnace set at $1100^{\circ} \mathrm{C}$ until constant weight was achieved. C.J. Coleman of ADS performed the wt. $\%$ oxide measurements using ADS procedures for wt. \% total solids measurements [11]. The wt. \% oxide data for the three simulants are shown in Table 3-22.

\subsubsection{Statistical Analysis}

T.B. Edwards of the Statistical Consulting Section of SRNL performed statistical analysis of elemental analysis data as a function of digestion methods. The full statistical analysis package is documented in three reports that address the analyses of the AY-102 simulant [12], the AZ-101 simulant [13], and the melter feed simulant consisting of AY-102/C-106 sludge and glass-formers/glass-modifiers [14]. 


\subsection{OBJECTIVES}

Test requirements were provided in the Statement of Work [2]. The basic objectives of the experimental program for the Phase I of this analytical development project are outlined in the Task Technical and QA Plan [1], pages 12-14.

Although the analytical precision and accuracy requirements have not yet been formally stipulated for the WTP, years of operating the Defense Waste Processing Facility at SRS have shown that a goal of $5 \%$ relative standard deviation for the precision of six or more replicate measurements of the major elements ( $>0.5 \mathrm{wt} \%$ on oxide basis) and $\pm 10 \%$ of the true value is an appropriate goal.

In order to meet the nine-hour or less turnaround time requirement for MFPV samples, no more than three hours can be allocated for performing up to eight digestions (the clock for digestions is considered to start after the sample vials have been removed from the pneumatic transport bottles and the sample vials have been sub-sampled and each sample weighed into the digestion crucible or bottle). We set as a criterion that an individual digestion could require no longer than one hour to perform.

\begin{tabular}{|c|c|c|}
\hline Test Objective & $\begin{array}{l}\text { Objective } \\
\text { Met (Y/N) }\end{array}$ & Discussion \\
\hline $\begin{array}{l}\text { 1. Test candidate digestion } \\
\text { methods on both HLW-2A } \\
\text { and HLW-2B matrices to } \\
\text { help method selection based } \\
\text { on analytical quality and the } \\
\text { time required for digestions. }\end{array}$ & Yes & 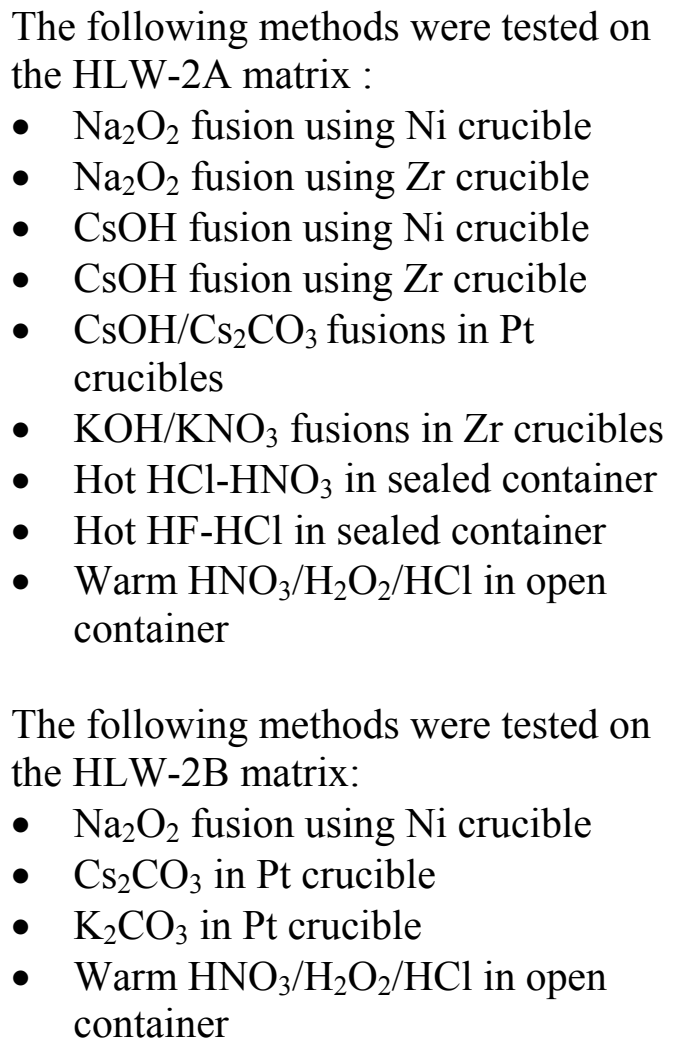 \\
\hline
\end{tabular}


WSRC-TR-2005-00169, REVISION 0

SRNL-RPP-2005-00023, REVISION 0

\begin{tabular}{|c|c|c|}
\hline Test Objective & $\begin{array}{l}\text { Objective } \\
\text { Met }(\mathrm{Y} / \mathrm{N})\end{array}$ & Discussion \\
\hline $\begin{array}{l}\text { 2. Demonstrate that the } \\
\text { individual method can be } \\
\text { performed in one hour or less } \\
\text { and that up to eight samples } \\
\text { can be digested by the method } \\
\text { in } 3 \text { hours or less. }\end{array}$ & Yes & $\begin{array}{l}\text { In the laboratory, up to eight } \\
\text { digestions can be performed in about } \\
\text { two hours. The true time required for } \\
\text { performing the methods in the } \\
\text { shielded cells will be determined in } \\
\text { the Time-and-Motion study in Phase } \\
\text { II. The nine-hour turnaround time } \\
\text { requirement for the entire analytical } \\
\text { scheme will be achievable with } \\
\text { adequate training of WTP Laboratory } \\
\text { staff. }\end{array}$ \\
\hline $\begin{array}{l}\text { 3. Obtain reliable results in terms } \\
\text { of accuracy and precision. }\end{array}$ & Yes & $\begin{array}{l}\text { Although accuracy and precision } \\
\text { criteria have not been set for WTP } \\
\text { analyses, a goal of } 5 \% \text { relative } \\
\text { standard deviation for precision of at } \\
\text { least } 3 \text { replicate measurements was } \\
\text { set for elements that would comprise } \\
\text { at least } 0.5 \text { wt. } \% \text { on the sludge } \\
\text { matrices converted to an oxide. A } \\
\text { goal of } \pm 10 \% \text { of the true value was } \\
\text { set for accuracy. For most sets of } \\
\text { determinations, these goals were met. }\end{array}$ \\
\hline $\begin{array}{l}\text { 4. Use QA/QC controls } \\
\text { including matrix spikes and } \\
\text { laboratory control standards. }\end{array}$ & Yes & $\begin{array}{l}\text { Both matrix spikes and laboratory } \\
\text { control standards were used. Normal } \\
\text { ADS QA/QC procedures and } \\
\text { protocols were followed in the ICP- } \\
\text { AES analyses of solutions. }\end{array}$ \\
\hline
\end{tabular}

\subsection{TEST EXCEPTIONS}

None 
WSRC-TR-2005-00169, REVISION 0

SRNL-RPP-2005-00023, REVISION 0

\subsection{RESULTS AND PERFORMANCE AGAINST SUCCESS OBJECTIVES}

\begin{tabular}{|l|l|}
\hline Success Criteria & $\begin{array}{l}\text { Explain How the Tests Did or Did Not Meet the } \\
\text { Success Criteria }\end{array}$ \\
\hline $\begin{array}{l}\text { 1. Analytical method must meet 9- } \\
\text { hour or less turnaround time } \\
\text { requirement. }\end{array}$ & The tests did meet the success criteria. \\
& $\begin{array}{l}\text { The recommended analytical approach has } \\
\text { characteristics needed for overall success in meeting } \\
\text { the 9-hour or less turnaround time goal. The } \\
\text { digestion methods are relatively simple to perform } \\
\text { and can be completed rapidly enough to meet WTP } \\
\text { design requirements. }\end{array}$ \\
\hline $\begin{array}{l}\text { 2. Analytical quality in terms of } \\
\text { precision, accuracy, and } \\
\text { sensitivity must be adequate to } \\
\text { support the WTP. }\end{array}$ & $\begin{array}{l}\text { The tests did meet the success criteria. Although the } \\
\text { analytical precision and accuracy requirements have } \\
\text { not yet been formally stipulated for the WTP, years } \\
\text { of operating the Defense Waste Processing Facility } \\
\text { at SRS has shown that a goal of } 5 \% \text { relative } \\
\text { standard deviation for precision and } \pm 10 \% \text { of the } \\
\text { true value for elements at 0.5 wt. \% on an oxide } \\
\text { basis is an appropriate goal. In general, the data } \\
\text { obtained in the course of the experiments met these } \\
\text { requirements. The overall data quality was } \\
\text { consistent with that typically observed in SRNL } \\
\text { when sludge and glass matrices are analyzed by } \\
\text { qualified technicians and professional staff. }\end{array}$ \\
\hline
\end{tabular}

\subsection{QUALITY REQUIREMENTS}

This high-level waste development work was conducted in accordance with the RPP-WTP QA requirements specified for work conducted by SRNL as identified in DOE IWO M0SRLE60. SRNL has provided matrices to WTP demonstrating compliance of the SRNL QA program with the requirements specified by WTP. Specific information regarding the compliance of the SRNL QA program with RW-0333P, Revision 10, NQA-1 1989, Part 1, Basic and Supplementary Requirements and NQA-2a 1990, Subpart 2.7 is contained in these matrices.

\subsection{C\&T TEST CONDITIONS}

A Statement of Work [2] was issued that specified the test objectives and conditions. 


\subsection{SIMULANT USE}

As specified in the WTP Statement of Work [2], AY-102/C-106 and AZ-101 WTP waste simulants were chosen to represent HLW-2A initial MFPV samples. In addition, the melter feed simulant that was prepared by adding glass-formers/glass-modifiers to AY-102/C-106 sludge simulant was chosen to represent HLW-2B MFPV samples. Actual radioactive AY102/C-106 sludge was characterized [15] by ADS. Several of the same digestion methods tested on the AY-102/C-106 simulant also were used on the actual waste. The digestion characteristics of the actual waste and the simulated waste are similar.

However, as a general disclaimer, no simulant is a perfect stand-in for actual high-level waste from waste tanks to evaluate digestion methods. The compounds used in simulants may have different solubility characteristics (potentially, more or less soluble) than those found in real waste. Hanford high-level waste sludge is particularly complex because of the many chemical processes carried out over the history of the Hanford Site. Certain waste streams may require different digestion/ICP-AES methods than discussed in this report because of the high concentrations of $\mathrm{Zr}, \mathrm{Bi}$, or other elements. Unquestionably, the digestion methods must be re-tested periodically to ensure their applicability on actual Hanford wastes.

\subsection{DISCREPANCIES AND FOLLOW-ON TESTS}

Discrepancies: None

Follow-on Tests: The follow-on testing is part the planned method development program and a natural consequence of dividing the tasks into two phases. Phase II tests will involve implementation of the digestion methods discussed in this Phase I interim report as part of a Time-and-Motion study to ensure that the methods can meet the nine-hour or less turnaround time and also achieve acceptable analytical quality. Moreover, additional development work toward a single digestion method applicable to WTP process control will be performed. 
WSRC-TR-2005-00169, REVISION 0

SRNL-RPP-2005-00023, REVISION 0

\subsection{DISCUSSION}

\subsection{METHOD DEVELOPMENT GOALS - RATIONALE FOR METHODS TESTED}

The method development goals for the chemical digestion/ICP-AES approach for WTP samples are discussed in the following section. Additional discussions are included in the Experimental Section.

- Develop a reliable, simple, and rapid digestion protocol applicable to both the HLW-2A and HLW-2B matrices that will achieve the nine-hour or less turnaround time.

Result: The proposed scheme of a sodium peroxide fusion digestion used in conjunction with a warm mixed-acid digestion yields two sets of solutions that when analyzed separately provide the required analyses. Since the \% relative standard deviation of determinations of major elements was less than $5 \%$, excellent precision was obtained. Absolute accuracy of the method is more difficult to assess due to lack of slurry standards, but good agreement of several digestion methods along with acceptable recoveries for glass standard analytes indicates accurate analyses. The scheme is relatively simple to perform remotely and, in terms of cell equipment, requires only an analytical balance to weigh the sample, a drying oven to dry the sample, and a muffle furnace to heat the samples to fusion temperature. The scheme is effective on both the HLW-2A and HLW-2B sample matrices.

Discussion: The WTP turnaround time requirement of nine hours or less for the elemental analysis of HLW-2A and HLW-2B samples breaks down to following task-time allocation:

\section{$\underline{\text { Task }}$}

Sample Receipt-Sample Preparation

ICP-AES Elemental Analysis

Data Review and Report

\section{$\underline{\text { Time Allocation for Success }}$}

5 hours

2-3 hours

1-2 hours

The main challenge to meeting the nine-hour turnaround time is the sample preparation step. Sample preparation includes removing the sample bottles from the pneumatic carrier bottle (rabbits), removing and weighing sub-samples from each sample vial, and dissolving the subsamples. For the purpose of setting method development goals, we allocated a total of two hours for removing the sample vials from the rabbits, sub-sampling, and weighing the samples to be dissolved. Therefore, only three hours could be allocated for the actual digestions and still have a reasonable expectation of achieving the 9-hour or less turnaround time goal. 
In order to meet the three-hour turnaround time for as many as eight digestions, plus standards, plus blanks, we set as a criterion that an individual digestion could take no longer than one hour. This criterion eliminated some methods from consideration for testing, such as the multi-heating step microwave-assisted mixed-acid digestion method [16] used for glass samples at the SRS Defense Waste Processing Facility. In fact, microwave heating techniques were not considered at length because the pressure vessels tend to be cumbersome to assemble in a shielded cell environment.

\section{FUSION METHODS:}

The fact that both the HLW-2A and HLW-2B samples will have significant concentrations of $\mathrm{SiO}_{2}$ (after the HLW-2B material is transferred from the MFPV to the melter, a tank heel of up to $30 \%$ will remain, ensuring that significant quantities of the glass-formers/glassmodifiers will be present in both HLW-2A and HLW-2B samples) means that digestions based on either alkali fusions or $\mathrm{HF}$ are required to dissolve the $\mathrm{SiO}_{2}$. HF is very effective for dissolving $\mathrm{SiO}_{2}$, but leads to high corrosion rates in facilities and adds the potential for a serious HF spill due to increased handling of this reagent. Another problem with prolonged use of HF is that attack of the cell windows and other cell equipment can result in costly facility repairs. The SRS Defense Waste Processing Facility Laboratory recently replaced the alpha shields on all the cell windows because HF attack on the shields had impaired clarity.

Alkali fusions eliminate the need for $\mathrm{HF}$ to dissolve $\mathrm{SiO}_{2}$. An important consideration for favoring the alkali fusions for $\mathrm{SiO}_{2}$ determinations is that the attack of HF on the ICP-AES spray chamber/nebulizer system can lead to high Si biases unless an HF corrosion resistant spray chamber/nebulizer system is used as well as careful checks and corrections for Si blank values. Furthermore, insoluble fluorides can produce low biases of certain elements. This problem can be corrected to some extent by adding a fluoride complexing reagent such as boric acid to the solution. However, since boron determinations are required, either a second digestion or a split solution protocol (analyzing solutions with and without boric acid) would be required.

Properly performed sodium peroxide fusions normally result in complete digestion of highlevel waste sludge and glass matrices, even when $\mathrm{HNO}_{3}$ is used to dissolve the flux residue. The sodium peroxide method offers the possibility that refractory WTP components such as $\mathrm{SiO}_{2}$ and metal compounds can be dissolved without using either $\mathrm{HF}$ or $\mathrm{HCl}$. The sodium peroxide fusion digestions on the HLW-2A matrix (Table 3-1 and Table 3-2 for AY-102/C106; and Table 3-3 for AZ-101) and the HLW-2B matrix as both a slurry of melter feed (Table 3-4) and as a melter feed converted to glass (Table 3-5) resulted in clear solutions from which ICP-AES analyses of high precision were obtained. 


\section{WSRC-TR-2005-00169, REVISION 0 SRNL-RPP-2005-00023, REVISION 0}

The sodium peroxide method has, as have most of the common alkali fusion methods based on salts of $\mathrm{Na}, \mathrm{Li}$, and $\mathrm{K}$, the serious flaw that it contains an alkali metal (Na) that must be measured reliably in WTP matrices. Because alkali fusions are normally carried out in either $\mathrm{Zr}$ or Ni crucibles, analyses of these metals are precluded by attack on the crucible. Lithium borate salts are commonly used for digesting silicate-bearing materials and these fusions are carried out in platinum. However, both Li and B must be measured on both HLW-2A and HLW-2B samples for process control. To summarize the problem with alkali fusions, most preclude the determination of at least two of the required elemental analyses for WTP process control.

A possible solution to these problems that would allow measurement of both required alkali elements and the crucible element is the use of cesium salts for the fusion methods. Cesium hydroxide fusions were introduced [4] for glass dissolutions at SRNL a number of years ago to avoid the problem of adding a required alkali metal during the digestion. Since $\mathrm{Zr}$ is usually not an important element in SRS matrices, glass could be made in a platinum crucible and then a shard or wafer of glass transferred to a $\mathrm{Zr}$ crucible for cesium hydroxide fusions. $\mathrm{Zr}$ is an important element in Hanford high-level waste, eliminating this approach as a cureall for the WTP and necessitating a second digestion method. However, cesium hydroxide fusions were applied to AY-102/C-106 sludge simulant in both $\mathrm{Zr}$ (Table 3-6) and Ni crucibles (Table 3-7) as a possible dual digestion scheme and also as a possible complementary method to sodium peroxide fusions. The cesium hydroxide digestion of the HLW-2A matrix did not result in complete digestion, as evidenced by relatively poor ICPAES results.

To avoid the Zr-Ni crucible problem, platinum crucibles were considered because platinum will not be measured for routine process control. Since hydroxide ion corrosively attacks platinum crucibles whereas alkali carbonates are compatible with platinum, cesium carbonate fusions in platinum crucibles were tested. Cesium carbonate digestions of glass wafers have been tested [8] as a potential single digestion scheme for glass samples in the SRS Defense Waste Processing Facility. Cesium carbonate is commercially available at high purity (99.994\% pure on a metals basis). Although trace levels of alkali elements are found in the commercially available cesium carbonate, accurate measurements of $\mathrm{Li}, \mathrm{Na}$, and $\mathrm{K}$ can be obtained at concentrations typical of sludge and glass matrices.

The cesium carbonate fusion method on the HLW-2A simulant AY-102/C-106 produced too many insoluble residues for a reliable analysis, particularly with $\mathrm{HNO}_{3}$ used as the digestion acid. A possible mechanism for the incomplete digestion is that the sludge components become more refractory before the cesium carbonate flux temperature can be reached (at least $900^{\circ} \mathrm{C}$ before the flux becomes free-flowing). An improvement in performance was obtained by adding a solution of cesium hydroxide which has a melting point of less than $300{ }^{\circ} \mathrm{C}$ to the slurry of HLW-2A matrix before drying the sludge. The mixture of cesium hydroxide and cesium carbonate in a platinum crucible minimized the corrosion of the platinum crucible and resulted in good elemental determinations (Table 3-8) when $\mathrm{HCl}$ was used as the digestion acid. The solid that remained after the $\mathrm{Cs}_{2} \mathrm{CO}_{3} / \mathrm{CsOH}$ digestion was identified by $\mathrm{x}$-ray diffraction as cesium platinum chloride, $\mathrm{Cs}_{2} \mathrm{PtCl}_{6}$, showing that corrosion of the platinum crucible from attack of the hydroxide had not been eliminated. Our overall impression was that this method has promise as a possible single digestion method, but that it requires additional testing to confirm applicability on waste samples. 
The cesium carbonate method was very successful when applied to the HLW-2B melter feed matrix with glass-forming chemicals. Cesium carbonate fusions carried out in platinum crucibles on both the HLW-2B matrix as a dried powder (Table 3-9) and as glass wafers made by vitrifying the melter feed powder (Table 3-10) produced clear solutions and reliable ICP-AES analyses using $\mathrm{HNO}_{3}$ as the digestion acid. Apparently, the glass-forming chemicals in the HLW-2B matrix assist with the oxidizing/complexing power of the cesium carbonate melt. Since cesium hydroxide was not required as a co-reagent to digest the melter feed, there was little evidence of cesium carbonate fusions severely attacking Pt crucibles.

The analogous potassium carbonate fusion applied to the glass was also tested (Table 3-13) should the concentration of $\mathrm{K}$ in the Hanford waste stream be inconsequential for glass processing and durability. For reasons not apparent after the small number of experiments, the potassium carbonate fusions were not as successful as the cesium carbonate fusions. Insoluble material and slightly lower elemental analyses were observed for the potassium carbonate fusions of glass versus the cesium carbonate fusions.

Although the cesium carbonate fusion could provide a single digestion method for the HLW-2B matrix both as melter feed powder and as glass, we believe that different digestion methods for the HLW-2A and HLW-2B samples should be avoided to simplify cell operations. Based on the fact that the presence of glass-forming $\mathrm{SiO}_{2}$ in the sample appears to improve the effectiveness of the cesium carbonate flux, additional experiments were done with other glass formers, such as $\mathrm{GeO}_{2}$ and $\mathrm{P}_{2} \mathrm{O}_{5}$, added to the HLW-2A matrix. Results obtained so far have been mixed, with some indication that the added glass formers help with the cesium carbonate fusion digestion of the HLW-2A sludge. In addition, experiments were done by adding $\mathrm{CsNO}_{3}$ both as a solution to the slurry sample before drying and as a solid to the $\mathrm{Cs}_{2} \mathrm{CO}_{3}$ in an attempt to increase the oxidizing power of the flux and thereby improve digestion of the HLW-2A matrix. The addition of nitrate ion to the flux resulted in significant corrosion of the Pt crucible and did not result in a satisfactory digestion method.

The practical benefits of developing a single digestion method applicable to both the HLW-2A and HLW-2B matrices are important enough to continue the investigative work. However, at this time, a robust single method that fulfills all WTP requirements is not available.

$\mathrm{KOH} / \mathrm{KNO}_{3}$ fusion method in $\mathrm{Zr}$ crucibles was applied to the HLW-2A matrix as the AY-102/C-106 simulant (Table 3-11) and as the AZ-101 simulant (Table 3-12). The $\mathrm{KOH} / \mathrm{KNO}_{3}$ method in $\mathrm{Zr}$ crucibles was studied as a possible complementary method to sodium peroxide fusions in Ni crucibles. This method is one of the routine methods used at the Hanford 222-S Laboratory [5] and at PNNL. SRNL also used this method in characterization of the actual AY-102/C-106 sludge [15]. Some solids were apparent after the digestions, similar to those observed with the cesium hydroxide fusions. As with the cesium hydroxide fusions, the performance of the method improved with use of $\mathrm{HCl}$ rather than $\mathrm{HNO}_{3}$ for the digestion acid to achieve faster digestions. Table 3-11 and Table 3-12 are from ICP-AES analyses of $\mathrm{KOH} / \mathrm{KNO}_{3}$ fusions with $\mathrm{HCl}$ as the uptake acid. 


\section{MIXED-ACID DIGESTION METHODS:}

The warm-acid method was devised and tested after it became apparent that a single digestion scheme would not be available and that the sodium peroxide method would be the backbone of the analytical approach. Focus shifted to find the simplest, quickest method for accurately measuring sodium and nickel precluded by the sodium peroxide fusion method carried out in nickel crucibles. Three separate mixed-acid digestions were performed on the HLW-2A matrix to help select a suitable complementary method to the sodium peroxide fusion method:

1) A mixture of $\mathrm{HF}-\mathrm{HCl}$ was heated in a Teflon pressurized container. Boric acid was not used to complex free fluoride because the B determinations from a non-fusion digestion were of interest. Considerable white solids remaining after the digestion were removed by filtration before elemental analysis (Table 3-17).

2) A mixture of 3 parts $\mathrm{HCl}$ and 1 part $\mathrm{HNO}_{3}$ (aqua regia) was also heated in a Teflon pressurized container analogous to the $\mathrm{HF}-\mathrm{HCl}$ method. Boiling aqua regia is used in tandem with sodium peroxide fusion digestions at SRS to characterize SRS waste tank sludge prior to transfer to the Defense Waste Processing Facility. The considerable white solids remaining after the hot aqua regia digestion were removed by filtration before the ICP-AES analysis of the HLW-2A sludge (Table 3-18).

3) The other mixed acid method applied to the HLW-2A matrix for 2 simulants, AY-102/ C-106 (Table 3-14), and AZ-101 (Table 3-15), did not use external heating but instead relied on chemical reactions to warm the solution. The rapid chemical decomposition of $5 \mathrm{~mL}$ of $30 \% \mathrm{H}_{2} \mathrm{O}_{2}$ and caustic waste sample in $15 \mathrm{~mL}$ concentrated $\mathrm{HNO}_{3}$ solution created a warm $\left(70-80^{\circ} \mathrm{C}\right)$, frothy mixture that became clearer but did not completely clarify $\left(\mathrm{SiO}_{2}\right.$ is almost completely insoluble in this acid matrix) upon addition of $5 \mathrm{~mL}$ of concentrated $\mathrm{HCl}$. The concentrated acid solution was diluted to $500 \mathrm{~mL}$, filtered, and diluted five-fold prior to elemental analysis. This method was also used for the HLW-2B matrix as AY-102/C-106 sludge and glass-formers in slurry form (Table 3-16). No attempt was made to apply this method to glass wafers since this acid mixture will not significantly attack glass. For the Time-and-Motion study in Phase II, the dilution will be to approximately $1000 \mathrm{~mL}$ to eliminate the time-consuming serial dilution step prior to $\mathrm{Na}$ and $\mathrm{Ni}$ determinations by ICP-AES. There was no indication of low bias for $\mathrm{Na}$ or $\mathrm{Ni}$ determinations from this method versus the other acid methods or alkali fusion methods. This method could be the preferred method for $\mathrm{Li}, \mathrm{B}, \mathrm{Na}$, and $\mathrm{Zn}$ introduced as glassformers/glass-modifiers because the low-dissolved solid matrix is conducive to superior ICP-AES analyses. Boron is prone to slight losses due to volatility in some alkali fusions, so the warm acid method would be preferred for B determinations. The "before and after" analyses of the glass-formers/glass-modifiers will be of particular interest in the WTP to ensure that the prescribed amounts of these materials are in the HLW-2B sample before feeding the glass melter. The $\mathrm{SiO}_{2}$ must be measured from the sodium peroxide fusion, but the other glass-formers/glass-modifiers are readily soluble in dilute acid. The warm mixed-acid method should be a reliable, fast, and convenient digestion method to measure these elements. 
WSRC-TR-2005-00169, REVISION 0

SRNL-RPP-2005-00023, REVISION 0

\section{- Eliminate or minimize the use of halide acids (HF, HCl) for digestions}

Result: The proposed scheme uses no $\mathrm{HF}$ and a small volume of $\mathrm{HCl}$, the necessity of which can be evaluated periodically in the WTP. Some Hanford high-level waste may have high levels of $\mathrm{Zr}$ which could benefit from addition of HF. The effectiveness of the proposed digestion methods will have to be re-evaluated prior to these sludges being processed.

\section{- Test the effectiveness of using matrix spikes and laboratory control standards for QC purposes}

Result: Matrix spikes and laboratory control standards were used in conjunction with every digestion method tested. Although the matrix spikes were measured with reasonable reliability, and they have their place in the method development phase, we find them of minimal use for ascertaining analytical quality and recommend that WTP not use them for routine process control analyses.

Laboratory control standards have much more technical merit than matrix spikes, particularly when they are in the same form and composition of the samples. We recommend that a true matrix laboratory control standard be made available for digestion and analysis throughout the life of the WTP. This would involve the use of slurry simulants as laboratory control standards instead of glass, since the most likely routine analytical scenario for the WTP does not include converting the melter feed samples into glass. However, glass samples from the WTP will be analyzed to determine product consistency and durability. Glass standards will be important to the analytical QC protocol for these samples.

\section{- Provide a statistical analysis of the analytical results}

Result: The statistical analysis of the data by T.B. Edwards of SRNL's Statistical Consulting Section was documented in three separate reports, one for each of the three simulants tested AY-102/C-106 [12], AZ-101, [13], and AY-102/C-106 plus glassformers/glass-modifiers[14]. The statistical analysis helps to show graphically information within the data tables. One of the most useful statistical tools is the comparison of element-by-element measurements as a function of each of the digestion methods. For example, $\mathrm{Ca}$ values are higher from the sodium peroxide fusion than from all other methods. The first reaction to these data might be that the sodium peroxide fusions were simply more effective at dissolving $\mathrm{Ca}$ compounds. In fact, the $\mathrm{Ca}$ measurements were high in the $\mathrm{Na}_{2} \mathrm{O}_{2}$ blank, suggesting that the higher values were due to contamination in the sodium peroxide and not the result of better digestions. Statistical analysis clearly documented higher $\mathrm{Ca}$ values from the sodium peroxide fusion blanks as the probable source of the higher Ca values from this digestion method. 
Statistical analysis of the data also is important for comparing digestion approaches. Since the tandem digestion approach of sodium peroxide fusions and warm mixed-acid is being considered for Phase II study, a statistical comparison of the data from these two methods and the data from an alternative method was done. The tandem digestion approach was compared with $\mathrm{KOH} / \mathrm{KNO}_{3}$ for $\mathrm{AY}-102 / \mathrm{C}-106$ [12] and $\mathrm{AZ}-101$ [13] simulants and compared with $\mathrm{Cs}_{2} \mathrm{CO}_{3}$ results for the AY-102/C-106 sludge + glass formers [14]. The precision of the analyses was excellent and, for some measurements, there were statistical differences that might not be chemically significant enough to affect WTP processing. That being said, the statistical treatment clearly shows that analytical differences can be expected as a function of digestion method.

The ICP-AES elemental analyses of the three simulants tested are shown in Table 3-1 through Table 3-18. The data tables are grouped by digestion type. 
WSRC-TR-2005-00169, REVISION 0 SRNL-RPP-2005-00023, REVISION 0

Table 3-1. Elemental Analysis of AY-102/C-106 Simulant -

WTP Sample Type: HLW-2A -

Digestion Method: Sodium Peroxide-Sodium Hydroxide Fusion in $\mathrm{Zr}$ crucibles

\begin{tabular}{|c|c|c|c|c|c|c|c|c|c|c|c|c|c|c|}
\hline Element $^{\mathrm{a}}$ & $\begin{array}{l}\text { Blank } \\
(\mu \mathrm{g} / \mathrm{g})\end{array}$ & $\begin{array}{c}\text { Trial } \\
1 \\
(\mu \mathrm{g} / \mathrm{g})\end{array}$ & $\begin{array}{c}\text { Trial } \\
2 \\
(\mu \mathrm{g} / \mathrm{g})\end{array}$ & $\begin{array}{c}\text { Trial } \\
3 \\
(\mu \mathrm{g} / \mathrm{g})\end{array}$ & $\begin{array}{l}\text { Avg. } \\
(\mu \mathrm{g} / \mathrm{g})\end{array}$ & (\%) & $\begin{array}{c}\text { Spike }^{\text {b. }} \\
1 \\
(\mu \mathrm{g} / \mathrm{g})\end{array}$ & $\begin{array}{c}\text { Spike }^{b .} \\
2 \\
(\mu \mathrm{g} / \mathrm{g})\end{array}$ & $\begin{array}{l}\text { Spike }^{\text {b. }} \\
\text { Avg. } \\
(\mu g / g)\end{array}$ & $\begin{array}{c}\text { Spike }^{\text {b. }} \\
\text { Recovery } \\
(\%)\end{array}$ & $\begin{array}{c}\text { LCS } \\
\text { Tria1 } \\
1 \\
(\mu \mathrm{g} / \mathrm{g})\end{array}$ & $\begin{array}{c}\text { LCS } \\
\text { Trial } \\
2 \\
(\mu \mathrm{g} / \mathrm{g}) \\
\end{array}$ & $\begin{array}{l}\text { LCS } \\
\text { Avg. } \\
(\mu \mathrm{g} / \mathrm{g})\end{array}$ & (\%) \\
\hline $\mathrm{Ag}$ & 39 & 633 & 601 & 511 & 582 & 11 & $\begin{array}{c}0.77 \\
\mathrm{mg} / \mathrm{L}\end{array}$ & $\begin{array}{r}0.82 \\
\mathrm{mg} / \mathrm{L}\end{array}$ & $\begin{array}{c}0.79 \\
\mathrm{mg} / \mathrm{L}\end{array}$ & $99 \%$ & 160 & 133 & 147 & NA \\
\hline $\mathrm{Al}$ & $<164$ & 18000 & 18000 & 17900 & 18000 & 1 & 18100 & 17900 & 18000 & NA & 23200 & 23500 & 23350 & -7 \\
\hline B & $<65$ & $<57$ & $<66$ & $<61$ & $<66$ & NA & $<57$ & $<57$ & $<57$ & NA & 24600 & 25200 & 24900 & -7 \\
\hline $\mathrm{Ba}$ & $<14$ & 595 & 585 & 577 & 586 & 2 & 596 & 587 & 592 & $\mathrm{NA}$ & 813 & 828 & 821 & +4 \\
\hline $\mathrm{Ca}$ & 540 & 2570 & 2710 & 2620 & 2630 & 3 & 2870 & 2870 & 2870 & NA & 11900 & 12000 & 11950 & +17 \\
\hline $\mathrm{Cd}$ & $<38$ & 86.1 & 81.1 & 86.8 & 84.7 & 4 & $\begin{array}{c}0.82 \\
\mathrm{mg} / \mathrm{L}\end{array}$ & $\begin{array}{c}0.82 \\
\mathrm{mg} / \mathrm{L}\end{array}$ & $\begin{array}{c}0.82 \\
\mathrm{mg} / \mathrm{L}\end{array}$ & $102 \%$ & $<118$ & $<117$ & $<118$ & NA \\
\hline $\mathrm{Ce}$ & 243 & 1050 & 1020 & 996 & 1022 & 3 & 1090 & 1070 & 1080 & NA & 996 & 1090 & 1043 & NA \\
\hline $\mathrm{Cr}$ & $<67$ & 823 & 817 & 792 & 811 & 2 & 798 & 822 & 810 & NA & 527 & 561 & 544 & -15 \\
\hline $\mathrm{Cu}$ & $<22$ & 142 & 140 & 140 & 141 & 1 & 152 & 146 & 149 & NA & $<68$ & $<67$ & $<68$ & NA \\
\hline $\mathrm{Fe}$ & $<92$ & 63500 & 63700 & 62900 & 63400 & 1 & 63500 & 62800 & 63150 & NA & 97900 & 99700 & 98800 & +1 \\
\hline $\mathrm{K}$ & 1330 & 1410 & 1490 & 1480 & 1460 & 3 & 1450 & 1380 & 1415 & NA & 27000 & 28000 & 27500 & +22 \\
\hline $\mathrm{La}$ & 107 & 659 & 631 & 626 & 639 & 3 & 656 & 648 & 652 & NA & 431 & 403 & 417 & NA \\
\hline $\mathrm{Li}$ & 55 & 63.4 & 54.5 & 48.8 & 55.6 & 13 & 63.9 & 63.2 & 63.5 & NA & 14900 & 15000 & 14950 & 0 \\
\hline $\mathrm{Mg}$ & $<13$ & 612 & 610 & 604 & 611 & 1 & 665 & 674 & 670 & NA & 4900 & 5020 & 4960 & -5 \\
\hline $\mathrm{Mn}$ & $<6$ & 14000 & 14000 & 13800 & 13900 & 1 & 14000 & 13800 & 13900 & NA & 14400 & 14600 & 14500 & -1 \\
\hline Mo & $<271$ & 247 & 326 & 259 & 277 & 15 & 249 & 282 & 265 & NA & $<846$ & $<833$ & $<846$ & NA \\
\hline $\mathrm{Na}$ & \multicolumn{14}{|c|}{ Not Measured-Na introduced in fusion reagents } \\
\hline $\mathrm{Ni}$ & $<132$ & 2030 & 2080 & 2020 & 2040 & 2 & 2040 & 2060 & 2050 & NA & 8150 & 8330 & 8240 & 0 \\
\hline $\mathrm{P}$ & $<1360$ & $<1180$ & $<1370$ & $<1260$ & $<1360$ & NA & $<1180$ & $<1180$ & $<1180$ & NA & $<4240$ & $<4170$ & $<4240$ & NA \\
\hline $\mathrm{Pb}$ & $<955$ & 3140 & 3060 & 3030 & 3180 & 2 & 3200 & 3120 & 3160 & NA & $<2980$ & $<2940$ & $<2980$ & NA \\
\hline $\mathrm{S}$ & $<401$ & $<348$ & $<406$ & $<373$ & $<401$ & NA & $\begin{array}{c}0.90 \\
\mathrm{mg} / \mathrm{L}\end{array}$ & $\begin{array}{r}0.90 \\
\mathrm{mg} / \mathrm{L}\end{array}$ & $\begin{array}{r}0.90 \\
\mathrm{mg} / \mathrm{L}\end{array}$ & $113 \%$ & $<1250$ & $<1230$ & $<1240$ & NA \\
\hline $\mathrm{Sb}$ & $<103$ & 332 & 302 & 280 & 305 & 9 & $\begin{array}{r}0.80 \\
\mathrm{mg} / \mathrm{L}\end{array}$ & $\begin{array}{r}0.80 \\
\mathrm{mg} / \mathrm{L}\end{array}$ & $\begin{array}{r}0.80 \\
\mathrm{mg} / \mathrm{L}\end{array}$ & $100 \%$ & 751 & 810 & 780 & NA \\
\hline $\mathrm{Si}$ & $<94$ & 18800 & 18900 & 18600 & 18800 & 1 & 19000 & 18700 & 18850 & NA & 23200 & 23600 & 23400 & +4 \\
\hline $\mathrm{Sn}$ & $<836$ & 767 & $<847$ & $<779$ & $<847$ & NA & $<726$ & $<726$ & $<726$ & NA & $<2610$ & $<2600$ & $<2600$ & NA \\
\hline $\mathrm{Sr}$ & 134 & 981 & 1030 & 1000 & 1000 & 2.4 & 1050 & 1060 & 1055 & NA & 2610 & 2660 & 2635 & $>+100$ \\
\hline Th & $<33$ & $<28$ & $<33$ & $<30$ & $<33$ & NA & $\begin{array}{c}0.79 \\
\mathrm{mg} / \mathrm{L}\end{array}$ & $\begin{array}{c}0.79 \\
\mathrm{mg} / \mathrm{L}\end{array}$ & $\begin{array}{c}0.79 \\
\mathrm{mg} / \mathrm{L}\end{array}$ & $99 \%$ & $<102$ & $<100$ & $<100$ & NA \\
\hline $\mathrm{Ti}$ & $<13$ & $<11$ & $<13$ & $<12$ & $<13$ & NA & $<11$ & $<11$ & $<11$ & $<11$ & 6930 & 7040 & 6985 & +1 \\
\hline $\mathrm{Tl}$ & $<186$ & 163 & 354 & 235 & $<354$ & $\mathrm{NA}$ & $\begin{array}{r}0.92 \\
\mathrm{mg} / \mathrm{L}\end{array}$ & $\begin{array}{c}0.94 \\
\mathrm{mg} / \mathrm{L}\end{array}$ & $\begin{array}{r}0.93 \\
\mathrm{mg} / \mathrm{L} \\
\end{array}$ & $116 \%$ & 696 & 780 & 738 & NA \\
\hline $\mathrm{U}$ & 101 & 329 & 325 & 376 & 343 & 8 & $\begin{array}{c}3.24 \\
\mathrm{mg} / \mathrm{L}\end{array}$ & $\begin{array}{c}2.62 \\
\mathrm{mg} / \mathrm{L}\end{array}$ & $\begin{array}{r}2.93 \\
\mathrm{mg} / \mathrm{L} \\
\end{array}$ & $73 \%$ & 460 & 699 & 579 & NA \\
\hline $\mathrm{Zn}$ & $<18$ & 168 & 159 & 163 & 163 & 3 & 181 & 171 & 176 & NA & 238 & 240 & 239 & +49 \\
\hline $\mathrm{Zr}$ & \multicolumn{14}{|c|}{ Not reported-Zr crucibles were used for these fusion digestions } \\
\hline $\begin{array}{l}\text { a. } \\
\text { b. }\end{array}$ & \multicolumn{14}{|c|}{$\begin{array}{l}\text { Elemental analysis concentrations of slurry simulant reported on wet slurry basis; The AY-102/C-106 simulant contained } 23.59 \pm 0.03 \% \\
\text { solids on oxide basis after heating at } 1100^{\circ} \mathrm{C} \text {. Elemental analysis concentrations of the LCS glass reported on dry powdered glass basis. } \\
\text { Concentrations of spiked elements reported in } \mathrm{mg} / \mathrm{L} \text { to facilitate comparison with the theoretical concentrations. Ag, } \mathrm{Cd}, \mathrm{S}, \mathrm{Sb}, \mathrm{Th}, \text { and } \mathrm{Tl} \\
\text { were spiked at } 0.8 \mathrm{mg} / \mathrm{L} \text { of the solutions after digestion; } \mathrm{U} \text { was spiked at } 4.0 \mathrm{mg} / \mathrm{L} \text { of the solutions after digestion. }\end{array}$} \\
\hline
\end{tabular}


WSRC-TR-2005-00169, REVISION 0

SRNL-RPP-2005-00023, REVISION 0

Table 3-2. Elemental Analysis of AY-102/C-106 Simulant WTP Sample Type: HLW-2A Digestion Method: Sodium Peroxide Fusion in Ni crucibles

\begin{tabular}{|c|c|c|c|c|c|c|c|c|c|c|c|c|c|c|}
\hline Element $^{\mathrm{a}}$ & $(\mu \mathrm{g} / \mathrm{g})$ & $\begin{array}{c}\text { Trial } \\
1\end{array}$ & $\begin{array}{c}\text { Trial } \\
2\end{array}$ & $(\mu \mathrm{g} / \mathrm{g})$ & $\begin{array}{c}\text { Trial } \\
4\end{array}$ & $(\mu \mathrm{g} / \mathrm{g})$ & (\%) & $\begin{array}{c}\text { Spike }^{\text {b. }} \\
\text { Recovery } \\
\text { (From } \\
\text { Trial 3) } \\
\text { (\%) }\end{array}$ & $\begin{array}{c}\text { Spike }^{\text {b. }} \\
\text { Recovery } \\
\text { (From } \\
\text { Trial 4) } \\
(\%)\end{array}$ & $\begin{array}{c}\text { Avg. } \\
\text { Spike }^{\text {b. }} \\
\text { Recovery }^{\text {(\%) }} \\
\end{array}$ & $\begin{array}{c}\text { LCS } \\
\text { Tria1 } \\
1 \\
(\mu \mathrm{g} / \mathrm{g}) \\
\end{array}$ & $\begin{array}{c}\text { LCS } \\
\text { Trial } \\
2 \\
\\
(\mu \mathrm{g} / \mathrm{g})\end{array}$ & $\begin{array}{l}\text { LCS } \\
\text { Avg. }\end{array}$ & Error \\
\hline $\mathrm{Ag}$ & $<34.4$ & 1190 & 1180 & 1190 & 1190 & 1190 & 1 & NA & NA & NA & $<66.9$ & $<65.2$ & $<66.0$ & NA \\
\hline $\mathrm{Al}$ & $<313$ & 17800 & 17700 & 17700 & 17800 & 17800 & 1 & NA & NA & $\mathrm{NA}$ & 22400 & 22500 & 22400 & -10 \\
\hline B & $<124$ & $<145$ & $<<152$ & $<120$ & $<135$ & $<152$ & NA & NA & NA & $\mathrm{NA}$ & 23700 & 22900 & 23300 & -13 \\
\hline $\mathrm{Ba}$ & 95.8 & 717 & 708 & 649 & 651 & 681 & 5 & NA & NA & NA & 1090 & 1020 & 1060 & +33 \\
\hline $\mathrm{Ca}$ & 349 & 2980 & 3120 & 2860 & 3140 & 2780 & 20 & NA & NA & NA & 12400 & 12200 & 12300 & +20 \\
\hline $\mathrm{Cd}$ & $<72.2$ & $<84.4$ & $<88.9$ & $<70.1$ & $<78.6$ & $<88.9$ & $\mathrm{NA}$ & NA & NA & NA & $<140$ & $<<137$ & $<140$ & NA \\
\hline $\mathrm{Ce}$ & $<419$ & 1340 & 1450 & 1290 & 1290 & 1180 & 15 & NA & NA & NA & 932 & 974 & 953 & NA \\
\hline $\mathrm{Cr}$ & 420 & 1310 & 1350 & 1040 & 1010 & 1180 & 15 & $\mathrm{NA}$ & NA & $\mathrm{NA}$ & 1790 & 1310 & 1550 & $>100$ \\
\hline $\mathrm{Cu}$ & $<41.3$ & 137 & 128 & 140 & 127 & 133 & 5 & $\mathrm{NA}$ & NA & NA & $<80.3$ & $<78.3$ & $<80.3$ & NA \\
\hline $\mathrm{Fe}$ & $<175$ & 67700 & 67600 & 67500 & 67000 & 67400 & 1 & NA & NA & NA & 102000 & 101000 & 10200 & +4 \\
\hline $\mathrm{K}$ & 1960 & 2560 & 2600 & $<1620$ & 2610 & $<2610$ & NA & NA & NA & NA & 26900 & 30900 & 28900 & +28 \\
\hline $\mathrm{La}$ & $<141$ & 721 & 695 & 671 & 707 & 698 & 3 & NA & NA & NA & $<274$ & 283 & $<283$ & NA \\
\hline $\mathrm{Li}$ & $<72.2$ & $<84.4$ & 90.3 & $<70.1$ & $<78.6$ & $<90.3$ & NA & NA & NA & NA & 16500 & 16600 & 16600 & +10 \\
\hline $\mathrm{Mg}$ & $<24.1$ & 645 & 647 & 660 & 645 & 649 & 1 & NA & NA & NA & 5190 & 5210 & 5200 & 0 \\
\hline $\mathrm{Mn}$ & $<10.3$ & 14800 & 14800 & 14800 & 14700 & 14800 & 1 & NA & NA & NA & 14800 & 14900 & 14800 & +1 \\
\hline Mo & 806 & 938 & 967 & 546 & 565 & blank & NA & NA & NA & NA & 1670 & 1630 & 1650 & NA \\
\hline $\mathrm{Na}$ & \multicolumn{14}{|c|}{ Not Measured-Na introduced in fusion reagents } \\
\hline $\mathrm{Ni}$ & \multicolumn{14}{|c|}{ Not Measured-Ni crucibles used in fusions } \\
\hline $\mathrm{P}$ & $<2580$ & $<3020$ & $<3180$ & $<2510$ & $<2810$ & $<3180$ & NA & NA & NA & NA & $<5020$ & $<4900$ & $<5020$ & NA \\
\hline $\mathrm{Pb}$ & $<1820$ & 3400 & 3830 & 3390 & 3250 & 3470 & 7 & NA & NA & NA & $<3540$ & $<3450$ & $<3540$ & NA \\
\hline $\mathrm{S}$ & $<763$ & $<892$ & $<940$ & $<741$ & $<831$ & $<940$ & NA & NA & NA & NA & $<1490$ & $<1450$ & $<1490$ & NA \\
\hline $\mathrm{Sb}$ & 1670 & 1920 & 1970 & 758 & 701 & $\begin{array}{r}< \\
\text { blank }\end{array}$ & NA & NA & NA & NA & 4260 & 3000 & 3630 & NA \\
\hline $\mathrm{Si}$ & $<179$ & 17000 & 16900 & 17300 & 17000 & 17000 & 1 & NA & NA & NA & 231000 & 233000 & 2320000 & +3 \\
\hline $\mathrm{Sn}$ & $<1590$ & $<1860$ & $<1960$ & $<1550$ & $<1730$ & $<1960$ & NA & NA & NA & NA & $<3100$ & $<3020$ & $<3020$ & NA \\
\hline $\mathrm{Sr}$ & 80.9 & 1080 & 1110 & 1040 & 1110 & 1080 & 3 & NA & NA & $\mathrm{NA}$ & 2710 & 2640 & 2680 & $>100$ \\
\hline $\mathrm{Th}$ & 67.9 & 74.6 & 89.8 & $<60.1$ & 72.2 & $<89.8$ & NA & $\mathrm{NA}$ & NA & $\mathrm{NA}$ & 175 & 143 & 159 & NA \\
\hline $\mathrm{Ti}$ & $<24.1$ & $<28.1$ & $<29.6$ & $<23.4$ & $<26.2$ & $<29.6$ & NA & NA & NA & NA & 7050 & 7070 & 7060 & +2 \\
\hline $\mathrm{Tl}$ & 375 & 559 & 584 & $<344$ & 401 & $<559$ & NA & NA & NA & NA & 1100 & 788 & 944 & NA \\
\hline $\mathrm{U}$ & 259 & 263 & 415 & 278 & 295 & 313 & 22 & NA & NA & NA & 679 & 478 & 578 & NA \\
\hline $\mathrm{Y}$ & $<344$ & $<402$ & $<423$ & $\begin{array}{c}1.95 \\
\mathrm{mg} / \mathrm{L}\end{array}$ & $\begin{array}{r}1.95 \\
\mathrm{mg} / \mathrm{L}\end{array}$ & $\begin{array}{c}1.95 \\
\mathrm{mg} / \mathrm{L}\end{array}$ & 1 & 98 & 98 & 98 & $<669$ & $<652$ & $<669$ & NA \\
\hline $\mathrm{Zn}$ & 1130 & 1270 & 1230 & 406 & 435 & $\begin{array}{r}\text { Less } \\
\text { than } \\
\text { blank }\end{array}$ & NA & NA & NA & NA & 2790 & 1840 & 1990 & $>100$ \\
\hline $\mathrm{Zr}$ & 97.2 & 993 & 962 & 735 & 770 & 865 & 15 & NA & NA & NA & 1110 & 1180 & 1140 & +19 \\
\hline $\begin{array}{l}\text { a. } \\
\text { b. }\end{array}$ & $\begin{array}{l}\text { Elementa } \\
\text { oxide bas } \\
\text { Concentr } \\
\text { digestion }\end{array}$ & tion of $\mathrm{s}$ & ked Y re & ons of $s$ & $\mathrm{~g} / \mathrm{L}$ to fa & $\begin{array}{l}\text { ant repo } \\
\text { alysis c } \\
\text { cilitate c }\end{array}$ & centra & $\begin{array}{l}\text { slurry bas } \\
\text { ons of the L } \\
\text { with the th }\end{array}$ & $\begin{array}{l}\text { The AY-1 } \\
\text { S glass rep } \\
\text { retical con }\end{array}$ & $\begin{array}{l}/ \mathrm{C}-106 \mathrm{sim} \\
\text { ted on dry } \\
\text { ntration. Y }\end{array}$ & $\begin{array}{l}\text { ant conta } \\
\text { wdered gl } \\
\text { as spiked }\end{array}$ & $\begin{array}{l}23.59 \\
\text { s basis. } \\
\text { to sampl }\end{array}$ & $\begin{array}{l}0.03 \% \text { sol } \\
\text { before the }\end{array}$ & \\
\hline
\end{tabular}


WSRC-TR-2005-00169, REVISION 0

SRNL-RPP-2005-00023, REVISION 0

Table 3-3. Elemental Analysis of AZ-101 Simulant -

Type of WTP Waste: HLW-2A -

Digestion Method: Sodium Peroxide Fusion in Ni Crucibles

\begin{tabular}{|c|c|c|c|c|c|c|c|c|c|c|c|}
\hline Element $^{\mathrm{a}}$ & $(\mu \mathrm{g} / \mathrm{g})$ & $\begin{array}{c}\text { Trial } \\
1\end{array}$ & $\begin{array}{c}\text { Trial } \\
2\end{array}$ & $\begin{array}{c}\text { Trial } \\
\mathbf{3}\end{array}$ & $(\mu \mathrm{g} / \mathrm{g})$ & $(\%)$ & $\begin{array}{c}\text { Spike }^{\text {b. }} \\
\text { Recovery } \\
\text { (From } \\
\text { Trial 3) } \\
\text { (\%) }\end{array}$ & $\begin{array}{c}\text { LCS } \\
\text { Tria1 } \\
1 \\
(\mu \mathrm{g} / \mathrm{g})\end{array}$ & $\begin{array}{c}\text { LCS } \\
\text { Trial } \\
2 \\
(\mu \mathrm{g} / \mathrm{g})\end{array}$ & $\begin{array}{l}\text { LCS } \\
\text { Avg. }\end{array}$ & Error \\
\hline $\mathrm{Ag}$ & $<14.5$ & 124 & 120 & 135 & 124 & 8 & NA & $<66.9$ & $<65.2$ & $<66.2$ & NA \\
\hline $\mathrm{Al}$ & $<132$ & 23400 & 23200 & 24700 & 23800 & 3 & $\mathrm{NA}$ & 24700 & 24800 & 24800 & -1 \\
\hline $\mathrm{B}$ & $<52.1$ & $<56.4$ & $<47.7$ & $<56.49$ & $<56.4$ & NA & NA & 24400 & 24300 & 24400 & -10 \\
\hline $\mathrm{Ba}$ & 57.2 & 501 & 499 & 497 & 506 & 1 & $\mathrm{NA}$ & 1000 & 934 & 967 & +22 \\
\hline $\mathrm{Ca}$ & 312 & 2600 & 2570 & 2570 & 2640 & 2 & $\mathrm{NA}$ & 12700 & 12500 & 12600 & +26 \\
\hline $\mathrm{Cd}$ & $<30.4$ & 3010 & 2990 & 3000 & 3050 & 1 & NA & $<140$ & $<<137$ & $<140$ & $\mathrm{NA}$ \\
\hline $\mathrm{Ce}$ & 258 & 1720 & 1730 & 1760 & 1770 & 3 & NA & 1190 & 1100 & 1140 & NA \\
\hline $\mathrm{Cr}$ & 232 & 694 & 745 & 738 & 726 & 4 & NA & 1360 & 950 & 1100 & +72 \\
\hline $\mathrm{Cu}$ & $<17.4$ & 150 & 163 & 150 & 154 & 5 & NA & $<80.3$ & $<78.3$ & $<80.3$ & NA \\
\hline $\mathrm{Fe}$ & 17.0 & 56000 & 55900 & 56700 & 56200 & 1 & NA & 102000 & 102000 & 102000 & +4 \\
\hline $\mathrm{K}$ & 6490 & 4450 & 4280 & 7350 & $\begin{array}{r}5360 \\
\text { (less } \\
\text { than } \\
\text { blank) } \\
\end{array}$ & NA & NA & 38700 & 45800 & 42250 & +87 \\
\hline $\mathrm{La}$ & 92.4 & 1660 & 1640 & 1670 & 1660 & 1 & NA & 431 & 441 & 436 & NA \\
\hline $\mathrm{Li}$ & 77.2 & 68.9 & 57.0 & 98.9 & $\begin{array}{r}75.0 \\
\text { (less } \\
\text { than } \\
\text { blank) } \\
\end{array}$ & NA & & 17400 & 17500 & 17400 & +17 \\
\hline $\mathrm{Mg}$ & $<10.1$ & 392 & 378 & 393 & 388 & 2 & NA & 5240 & 5220 & 5230 & +1 \\
\hline $\mathrm{Mn}$ & $<4.34$ & 1500 & 1490 & 1570 & 1520 & 3 & NA & 14900 & 14800 & 14800 & +1 \\
\hline Mo & 572 & 398 & 467 & 502 & 456 & 12 & NA & 2160 & 1780 & 1970 & NA \\
\hline $\mathrm{Na}$ & \multicolumn{11}{|c|}{ Not Measured-Na used in fusion reagent } \\
\hline $\mathrm{Ni}$ & \multicolumn{11}{|c|}{ Not Measured- Ni crucibles used in fusions } \\
\hline $\mathrm{P}$ & $<1090$ & $<1040$ & $<1040$ & $<1180$ & $<1180$ & NA & NA & $<5020$ & $<4900$ & $<5020$ & NA \\
\hline $\mathrm{Pb}$ & $<766$ & $<734$ & $<829$ & $<734$ & $<829$ & NA & NA & $<3540$ & $<3450$ & $<3540$ & NA \\
\hline $\mathrm{Sb}$ & 1320 & 690 & 690 & 762 & $\begin{array}{r}\text { Less } \\
\text { than } \\
\text { blank } \\
\end{array}$ & NA & NA & 4490 & 2990 & 3740 & NA \\
\hline $\mathrm{Si}$ & $<75.3$ & 3800 & 3800 & 3940 & 3850 & 2 & NA & 236000 & 236000 & 236000 & +5 \\
\hline $\mathrm{Sn}$ & $<670$ & 1520 & 1520 & 1530 & 1520 & 1 & NA & $<3100$ & $<3020$ & $<3020$ & NA \\
\hline $\mathrm{Sr}$ & 88.7 & 1300 & 1300 & 1320 & 1310 & 1 & NA & 2640 & 2580 & 2520 & $>100$ \\
\hline $\mathrm{Ti}$ & $<2.66$ & 87.5 & 87.5 & 90.4 & 88.5 & 2 & NA & 7100 & 7110 & 7100 & +3 \\
\hline $\mathrm{Y}$ & $<145$ & $<139$ & $<139$ & $\begin{array}{c}3.98 \\
\mathrm{mg} / \mathrm{L}\end{array}$ & NA & NA & $99 \%$ & $<669$ & $<652$ & $<669$ & NA \\
\hline $\mathrm{Zn}$ & 1030 & 361 & 361 & 416 & 379 & 8 & NA & 3120 & 2050 & 2590 & $>100$ \\
\hline $\mathrm{Zr}$ & 89.0 & 17400 & 17400 & 16600 & 17100 & 3 & NA & 888 & 1120 & 1004 & +5 \\
\hline b. & \multicolumn{11}{|c|}{$\begin{array}{l}\text { Elemental analysis concentrations of slurry simulant reported on wet slurry basis; The AZ-101 simulant } \\
\text { contained } 20.23 \pm 0.05 \% \text { solids on oxide basis after heating at } 1100{ }^{\circ} \mathrm{C} \text {. Elemental analysis concentrations of } \\
\text { the LCS glass reported on dry powdered glass basis. } \\
\text { Concentration of spiked Y reported in } \mathrm{mg} / \mathrm{L} \text { to facilitate comparison with the theoretical concentration. Y was } \\
\text { spiked into sample before the digestion so that the theoretical concentration was } 4.0 \mathrm{mg} / \mathrm{L} \text {. }\end{array}$} \\
\hline
\end{tabular}


WSRC-TR-2005-00169, REVISION 0

SRNL-RPP-2005-00023, REVISION 0

Table 3-4. Elemental Analysis of AY-102/C-106 Melter Feed as Dried Slurry WTP Sample Type: HLW-2B -

Sample Digestion Method: Sodium Peroxide Fusion in Ni Crucibles

\begin{tabular}{|c|c|c|c|c|c|c|c|c|c|c|c|c|}
\hline Element $^{a}$ & $(\mu \mathrm{g} / \mathrm{g})$ & $(\mu \mathrm{g} / \mathrm{g})$ & $(\mu \mathrm{g} / \mathrm{g})$ & $\begin{array}{c}\text { Trial } \\
\mathbf{3} \\
\\
(\mu \mathrm{g} / \mathrm{g}) \\
\end{array}$ & $\begin{array}{c}\text { Trial } \\
4 \\
(\mu \mathrm{g} / \mathrm{g}) \\
\end{array}$ & $(\mu \mathrm{g} / \mathrm{g})$ & $(\%)$ & $\begin{array}{c}\text { Avg. } \\
\text { Spike }^{\text {b. }} \\
\text { Recovery } \\
\text { (From } \\
\text { Trials } \\
3,4) \\
(\%) \\
\end{array}$ & $\begin{array}{c}\text { LCS } \\
\text { Tria1 } \\
1\end{array}$ & $\begin{array}{c}\text { LCS } \\
\text { Trial } \\
2\end{array}$ & $\begin{array}{l}\text { LCS } \\
\text { Avg. }\end{array}$ & Error \\
\hline $\mathrm{Ag}$ & $<34.4$ & 288 & 425 & 452 & 466 & 408 & 20 & NA & $<66.9$ & $<65.2$ & $<66.0$ & $\mathrm{NA}$ \\
\hline $\mathrm{Al}$ & $<313$ & 10200 & 10600 & 10500 & 10500 & 10400 & 2 & NA & 22400 & 22500 & 22400 & -10 \\
\hline $\mathrm{B}$ & $<124$ & 10100 & 10100 & 10300 & 10300 & 10200 & 1 & NA & 23700 & 22900 & 23300 & -13 \\
\hline $\mathrm{Ba}$ & 95.8 & 431 & 425 & 445 & 467 & 442 & 4 & NA & 1090 & 1020 & 1060 & +33 \\
\hline $\mathrm{Ca}$ & 349 & 1690 & 1830 & 2030 & 1920 & 1870 & 8 & NA & 12400 & 12200 & 12300 & +20 \\
\hline $\mathrm{Cd}$ & $<72.2$ & $<56.4$ & $<55.5$ & $<52.6$ & $<44.2$ & $<56.4$ & NA & NA & $<140$ & $<137$ & $<140$ & NA \\
\hline $\mathrm{Ce}$ & $<419$ & 772 & 818 & 874 & 727 & 798 & 8 & NA & 932 & 974 & 953 & NA \\
\hline $\mathrm{Cr}$ & 420 & 798 & 834 & 944 & 1090 & 916 & 14 & NA & 1790 & 1310 & 1550 & $>100$ \\
\hline $\mathrm{Cu}$ & $<41.3$ & 49.8 & 55.7 & 62.4 & 62.9 & 57.7 & 11 & NA & $<80.3$ & $<78.3$ & $<80.3$ & NA \\
\hline $\mathrm{Fe}$ & $<175$ & 37300 & 37900 & 37700 & 37400 & 37600 & 1 & NA & 102000 & 101000 & 102000 & +4 \\
\hline $\mathrm{K}$ & 1960 & 3480 & 3170 & 3450 & 3410 & 3380 & 4 & $\mathrm{NA}$ & 26900 & 30900 & 28900 & +28 \\
\hline $\mathrm{La}$ & $<141$ & 397 & 408 & 404 & 394 & 401 & 2 & NA & $<274$ & 283 & $<283$ & NA \\
\hline $\mathrm{Li}$ & $<72.2$ & 4720 & 4840 & 4790 & 4850 & 4800 & 1 & NA & 16500 & 16600 & 16600 & +10 \\
\hline $\mathrm{Mg}$ & $<24.1$ & 392 & 406 & 408 & 407 & 403 & 2 & NA & 5190 & 5210 & 5200 & 0 \\
\hline $\mathrm{Mn}$ & $<10.3$ & 8180 & 8280 & 8280 & 8200 & 8240 & 1 & NA & 14800 & 14900 & 14800 & +1 \\
\hline Mo & 806 & 764 & 811 & 998 & 1070 & 911 & 16 & NA & 1670 & 1630 & 1650 & NA \\
\hline $\mathrm{Na}$ & \multicolumn{12}{|c|}{ Not Measured-Na used in fusion reagent } \\
\hline $\mathrm{Ni}$ & \multicolumn{12}{|c|}{ Not Measured- Ni crucibles used in fusions } \\
\hline $\mathrm{P}$ & $<2580$ & $<2020$ & $<1980$ & $<1880$ & $<1580$ & $<2020$ & NA & NA & $<5020$ & $<4900$ & $<5020$ & NA \\
\hline $\mathrm{Pb}$ & $<1820$ & 2070 & 2340 & 2230 & 2420 & 2260 & 7 & NA & $<3540$ & $<3450$ & $<3540$ & NA \\
\hline $\mathrm{S}$ & $<763$ & $<596$ & $<586$ & $<556$ & $<467$ & $<596$ & NA & NA & $<1490$ & $<1450$ & $<1490$ & NA \\
\hline $\mathrm{Sb}$ & 1670 & 1660 & 1540 & 1950 & 2470 & 1900 & 22 & NA & 4260 & 3000 & 3630 & NA \\
\hline $\mathrm{Si}$ & $<179$ & 85200 & 87100 & 86300 & 85500 & 86000 & 1 & NA & 231000 & 233000 & 232000 & +3 \\
\hline $\mathrm{Sn}$ & $<1590$ & $<1240$ & $<1220$ & $<1160$ & $<<975$ & $<1240$ & NA & NA & $<3100$ & $<3020$ & $<3020$ & NA \\
\hline $\mathrm{Sr}$ & 80.9 & 630 & 656 & 713 & 693 & 673 & 6 & NA & 2710 & 2640 & 2680 & $>100$ \\
\hline $\mathrm{Th}$ & 67.9 & 63.9 & 55.5 & 72.2 & 75.5 & 66.7 & NA & NA & 175 & 143 & 159 & NA \\
\hline $\mathrm{Ti}$ & $<24.1$ & $<18.8$ & $<18.5$ & $<17.5$ & $<14.7$ & $<18.8$ & NA & NA & 7050 & 7070 & 7060 & +2 \\
\hline $\mathrm{Tl}$ & 375 & 311 & 382 & 366 & 314 & $\begin{array}{r}\text { Less } \\
\text { than } \\
\text { blank } \\
\end{array}$ & NA & NA & 1100 & 788 & 944 & NA \\
\hline $\mathrm{U}$ & 259 & $<134$ & 284 & 163 & $<105$ & $\begin{array}{r}\text { Less } \\
\text { than } \\
\text { blank } \\
\end{array}$ & NA & NA & 679 & 478 & 578 & NA \\
\hline $\mathrm{Y}$ & $<344$ & $<268$ & $<264$ & $\begin{array}{r}1.93 \\
\mathrm{mg} / \mathrm{L} \text { or } \\
96 \% \\
\text { recovery }\end{array}$ & $\begin{array}{r}1.96 \\
\mathrm{mg} / \mathrm{L} \text { or } \\
98 \% \\
\text { recovery }\end{array}$ & 1.95 & 1 & $97 \%$ & $<669$ & $<652$ & $<669$ & NA \\
\hline $\mathrm{Zn}$ & 1130 & 4040 & 4030 & 4350 & 4660 & 4270 & 7 & NA & 2790 & 1840 & 1990 & $>100$ \\
\hline$\overline{\mathrm{Zr}}$ & 97.2 & 634 & 642 & 664 & 676 & 654 & 3 & NA & 1110 & 1180 & 1140 & +19 \\
\hline b. & $\begin{array}{l}\text { Elementa } \\
\text { contained } \\
\text { reported } \\
\text { Concentr } \\
\text { sample be }\end{array}$ & $\begin{array}{l}\text { analysis } \\
36.92 \pm \\
\mathrm{n} \text { dry poy } \\
\text { tion of } \mathrm{sp} \\
\text { fore the }\end{array}$ & $\begin{array}{l}\text { Concentra } \\
.05 \% \text { so } \\
\text { dered gl } \\
\text { iked Y re } \\
\text { igestion }\end{array}$ & $\begin{array}{l}\text { ions of slur } \\
\text { ds on oxide } \\
\text { s basis. } \\
\text { orted in mg } \\
\text { that the the }\end{array}$ & $\begin{array}{l}\text { y simulant } \\
\text { basis after } \\
\text { L to facilit } \\
\text { oretical cor }\end{array}$ & $\begin{array}{l}\text { ported o } \\
\text { eating at } \\
\text { e compa }\end{array}$ & $\begin{array}{l}\text { wet sl } \\
100^{\circ} \mathrm{C} \\
\text { son wi } \\
\text { was } 2 .\end{array}$ & $\begin{array}{l}\text { Ely basis; } \mathrm{Tl} \\
\text { Elemental } \\
\text { the theore } \\
\mathrm{mg} / \mathrm{L} \text {. }\end{array}$ & $\begin{array}{l}\mathrm{AY}-102 / \\
\text { alysis con } \\
\text { al concen }\end{array}$ & $\begin{array}{l}-106 \mathrm{Mel} \\
\text { entration } \\
\text { ation. Y }\end{array}$ & $\begin{array}{l}\text { Feed sin } \\
\text { as the LCiked }\end{array}$ & $\begin{array}{l}\text { ulant } \\
\text { glass } \\
\text { nto }\end{array}$ \\
\hline
\end{tabular}


WSRC-TR-2005-00169, REVISION 0 SRNL-RPP-2005-00023, REVISION 0

Table 3-5. Elemental Analysis of AY-102/C-106 Melter Feed Vitrified into Glass WTP Sample Type: HLW-2B Sample Digestion Method: Sodium Peroxide Fusion in Ni Crucibles

\begin{tabular}{|c|c|c|c|c|c|c|c|c|c|c|c|c|}
\hline Element $^{a}$ & $(\mu \mathrm{g} / \mathrm{g})$ & $\begin{array}{c}\text { Trial } \\
1\end{array}$ & $\begin{array}{c}\text { Trial } \\
2\end{array}$ & $\begin{array}{c}\text { Trial } \\
\mathbf{3}\end{array}$ & $\begin{array}{c}\text { Trial } \\
4\end{array}$ & $(\mu \mathrm{g} / \mathrm{g})$ & RSD & $\begin{array}{c}\text { Avg. } \\
\text { Spike } \\
\text { Recovery } \\
\text { (from } \\
\text { trials } \\
3,4) \\
(\%) \\
\end{array}$ & $\begin{array}{c}\text { LCS } \\
\text { Tria1 } \\
1\end{array}$ & $\begin{array}{c}\text { LCS } \\
\text { Trial } \\
2\end{array}$ & $\begin{array}{l}\text { LCS } \\
\text { Avg. }\end{array}$ & Error \\
\hline $\mathrm{Ag}$ & $<34.4$ & 502 & 477 & 405 & 494 & 470 & 9 & NA & $<66.9$ & $<65.2$ & $<66.0$ & NA \\
\hline $\mathrm{Al}$ & $<313$ & 10600 & 10600 & 10600 & 11000 & 10700 & 2 & NA & 22400 & 22500 & 22400 & -10 \\
\hline B & $<124$ & 10100 & 9980 & 9930 & 9760 & 9940 & 1 & NA & 23700 & 22900 & 23300 & -13 \\
\hline $\mathrm{Ba}$ & 95.8 & 407 & 645 & 498 & 525 & 519 & 19 & NA & 1090 & 1020 & 1060 & +33 \\
\hline $\mathrm{Ca}$ & 349 & 1750 & 1700 & 1930 & 2200 & 1900 & 12 & NA & 12400 & 12200 & 12300 & +20 \\
\hline $\mathrm{Cd}$ & $<72.2$ & $<54.0$ & $<54.7$ & $<49.8$ & $<63.1$ & $<54.7$ & NA & NA & $<140$ & $<137$ & $<140$ & NA \\
\hline $\mathrm{Ce}$ & $<419$ & 813 & 892 & 785 & 851 & 829 & 7 & NA & 932 & 974 & 953 & NA \\
\hline $\mathrm{Cr}$ & 420 & 750 & 1950 & 1170 & 1320 & 1300 & 38 & NA & 1790 & 1310 & 1550 & $>100$ \\
\hline $\mathrm{Cu}$ & $<41.3$ & 60.8 & 89.7 & 62.6 & 63.2 & 69.1 & 20 & NA & $<80.3$ & $<78.3$ & $<80.3$ & NA \\
\hline $\mathrm{Fe}$ & $<175$ & 37900 & 37600 & 37900 & 39000 & 38100 & 2 & NA & 102000 & 101000 & 102000 & +4 \\
\hline $\mathrm{K}$ & 1960 & 3540 & 3500 & 3690 & 3890 & 3650 & 5 & NA & 26900 & 30900 & 28900 & +28 \\
\hline $\mathrm{La}$ & $<141$ & 401 & 412 & 412 & 434 & 415 & 3 & NA & $<274$ & 283 & $<283$ & NA \\
\hline $\mathrm{Li}$ & $<72.2$ & 4720 & 4690 & 4870 & 4910 & 4800 & 2 & NA & 16500 & 16600 & 16600 & +10 \\
\hline $\mathrm{Mg}$ & $<24.1$ & 413 & 304 & 406 & 410 & 383 & 14 & NA & 5190 & 5210 & 5200 & 0 \\
\hline $\mathrm{Mn}$ & $<10.3$ & 8310 & 8270 & 8310 & 8520 & 8350 & 1 & NA & 14800 & 14900 & 14800 & +1 \\
\hline Mo & 806 & 579 & 2270 & 1210 & 1490 & 1390 & 50 & NA & 1670 & 1630 & 1650 & NA \\
\hline $\mathrm{Na}$ & \multicolumn{12}{|c|}{ Not Measured-Na used in fusion reagent } \\
\hline $\mathrm{Ni}$ & \multicolumn{12}{|c|}{ Not Measured- Ni crucibles used in fusions } \\
\hline $\mathrm{P}$ & $<2580$ & $<1930$ & $<1960$ & $<1780$ & $<2260$ & $<2260$ & NA & NA & $<5020$ & $<4900$ & $<5020$ & NA \\
\hline $\mathrm{Pb}$ & $<1820$ & 2100 & 3030 & 2540 & 2590 & 2560 & NA & NA & $<3540$ & $<3450$ & $<3540$ & NA \\
\hline $\mathrm{S}$ & $<763$ & $<570$ & $<578$ & $<526$ & $<667$ & $<667$ & NA & NA & $<1490$ & $<1450$ & $<1490$ & NA \\
\hline $\mathrm{Sb}$ & 1670 & 1170 & 5450 & 2840 & 3330 & 3200 & 55 & NA & 4260 & 3000 & 3630 & NA \\
\hline $\mathrm{Si}$ & $<179$ & 86400 & 85200 & 86000 & 88300 & 86500 & 2 & NA & 231000 & 233000 & 2320000 & +3 \\
\hline $\mathrm{Sn}$ & $<1590$ & $<1190$ & 1370 & $<1100$ & $<1390$ & $<1390$ & NA & NA & $<3100$ & $<3020$ & $<3020$ & NA \\
\hline $\mathrm{Sr}$ & 80.9 & 652 & 682 & 706 & 775 & 704 & 7 & NA & 2710 & 2640 & 2680 & $>100$ \\
\hline $\mathrm{Th}$ & 67.9 & 49.7 & 186 & 106 & 103 & 111 & 51 & NA & 175 & 143 & 159 & NA \\
\hline $\mathrm{Ti}$ & $<24.1$ & $<18.0$ & $<18.2$ & $<16.6$ & $<21.0$ & $<21.0$ & NA & NA & 7050 & 7070 & 7060 & +2 \\
\hline $\mathrm{Tl}$ & 375 & 318 & 647 & 439 & 494 & 474 & 29 & NA & 1100 & 788 & 944 & NA \\
\hline $\mathrm{U}$ & 259 & 199 & 207 & 189 & 200 & 199 & 4 & NA & 679 & 478 & 578 & NA \\
\hline $\mathrm{Y}$ & $<344$ & $<257$ & $<260$ & $\begin{array}{r}1.93 \\
\mathrm{mg} / \mathrm{L} \text { or } \\
96 \% \\
\text { recovery }\end{array}$ & $\begin{array}{r}1.93 \\
\mathrm{mg} / \mathrm{L} \text { or } \\
96 \% \\
\text { recovery }\end{array}$ & $\begin{array}{c}1.93 \\
\mathrm{mg} / \mathrm{L}\end{array}$ & 0 & $96 \%$ & $<669$ & $<652$ & $<669$ & NA \\
\hline $\mathrm{Zn}$ & 1130 & 3750 & 6880 & 4980 & 5400 & 5250 & 25 & NA & 2790 & 1840 & 1990 & $>100$ \\
\hline $\mathrm{Zr}$ & 97.2 & 639 & 782 & 695 & 742 & 714 & 9 & NA & 1110 & 1180 & 1140 & +19 \\
\hline b. & \multicolumn{12}{|c|}{$\begin{array}{l}\text { Elemental analysis concentrations of slurry simulant reported on wet slurry basis; The AY-102/C-106 Melter Feed simulant } \\
\text { contained } 36.92 \pm 0.05 \% \text { solids on oxide basis after heating at } 1100{ }^{\circ} \mathrm{C} \text {. Elemental analysis concentrations of the LCS glass } \\
\text { reported on dry powdered glass basis. } \\
\text { Concentration of spiked Y reported in mg/L to facilitate comparison with the theoretical concentration. Y was spiked into } \\
\text { sample before the digestion so that the theoretical concentration was } 2.0 \mathrm{mg} / \mathrm{L} \text {. }\end{array}$} \\
\hline
\end{tabular}




\section{WSRC-TR-2005-00169, REVISION 0 SRNL-RPP-2005-00023, REVISION 0}

\section{Table 3-6. Elemental Analysis of AY-102/C-106 Simulant - WTP Sample Type: HLW-2A - Digestion Method: Cesium Hydroxide in $\mathrm{Zr}$ Crucible}

\begin{tabular}{|c|c|c|c|c|c|c|c|c|c|c|c|c|c|c|}
\hline Element $^{a}$ & 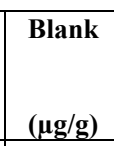 & $\begin{array}{c}\text { Trial } \\
1 \\
(\mu \mathrm{g} / \mathrm{g}) \\
\end{array}$ & $\begin{array}{c}\text { Trial } \\
2 \\
(\mu \mathrm{g} / \mathrm{g}) \\
\end{array}$ & $\begin{array}{c}\text { Trial } \\
\mathbf{3} \\
(\mu \mathrm{g} / \mathrm{g}) \\
\end{array}$ & $\begin{array}{l}\text { Avg. } \\
(\mu g / g)\end{array}$ & $\begin{array}{l}\text { RSD } \\
(\%) \\
\end{array}$ & $\begin{array}{c}\text { Spike }^{b} . \\
1 \\
(\mu \mathrm{g} / \mathrm{g})\end{array}$ & $\begin{array}{c}\text { Spike }^{b .} \\
2 \\
(\mu \mathrm{g} / \mathrm{g})\end{array}$ & $\begin{array}{l}\text { Spike } \\
\text { Avg. } \\
(\mu g / g)\end{array}$ & $\begin{array}{c}\text { Spike }^{\text {b. }} \\
\text { recovery } \\
(\%) \\
\end{array}$ & $\begin{array}{c}\text { LCS } \\
\text { Tria1 } \\
1 \\
(\mu \mathrm{g} / \mathrm{g}) \\
\end{array}$ & $\begin{array}{c}\text { LCS } \\
\text { Trial } 2 \\
(\mu \mathrm{g} / \mathrm{g})\end{array}$ & $\begin{array}{l}\text { LCS } \\
\text { Avg. } \\
(\mu g / g)\end{array}$ & $(\%)$ \\
\hline $\mathrm{Ag}$ & $<18.0$ & 647 & 682 & 581 & 637 & 8 & $\begin{array}{c}0.56 \\
\mathrm{mg} / \mathrm{L}\end{array}$ & $\begin{array}{c}0.65 \\
\mathrm{mg} / \mathrm{L}\end{array}$ & $\begin{array}{c}0.60 \\
\mathrm{mg} / \mathrm{L}\end{array}$ & $75 \%$ & 267 & 108 & 188 & NA \\
\hline $\mathrm{Al}$ & $<164$ & 17400 & 17300 & 17100 & 17270 & 1 & 17400 & 17300 & 17350 & NA & 22900 & 23000 & 22950 & -8 \\
\hline $\mathrm{B}$ & $<65.0$ & $<63.1$ & $<61.7$ & $<67.6$ & $<67.6$ & NA & $<63.1$ & $<63.1$ & $<63.1$ & NA & 24800 & 24500 & 24650 & -8 \\
\hline $\mathrm{Ba}$ & $<14.4$ & 559 & 562 & 555 & 559 & 1 & 559 & 559 & 559 & $\mathrm{NA}$ & 830 & 832 & 831 & +5 \\
\hline $\mathrm{Ca}$ & $<57.8$ & 2290 & 2290 & 2270 & 2280 & 1 & 2260 & 2300 & 2280 & $\mathrm{NA}$ & 10300 & 10500 & 10400 & +2 \\
\hline $\mathrm{Cd}$ & $<37.9$ & 82.1 & 77.2 & 72.1 & 77.1 & 6 & $\begin{array}{c}0.79 \\
\mathrm{mg} / \mathrm{L}\end{array}$ & $\begin{array}{c}0.79 \\
\mathrm{mg} / \mathrm{L}\end{array}$ & $\begin{array}{c}0.79 \\
\mathrm{mg} / \mathrm{L}\end{array}$ & $99 \%$ & $<125$ & $<120$ & $<125$ & NA \\
\hline $\mathrm{Ce}$ & $<220$ & 677 & 700 & 549 & 642 & 13 & 560 & 641 & 600 & NA & $<727$ & $<697$ & $<727$ & NA \\
\hline $\mathrm{Cr}$ & $<66.8$ & 788 & 765 & 752 & 768 & 2 & 744 & 765 & 755 & NA & 516 & 527 & 522 & -18 \\
\hline $\mathrm{Cu}$ & $<21.7$ & 130 & 130 & 125 & 128 & 2 & 144 & 137 & 141 & NA & $<71.5$ & $<68.5$ & $<71.5$ & NA \\
\hline $\mathrm{Fe}$ & $<92.0$ & 63200 & 63000 & 62100 & 62770 & 1 & 63000 & 63000 & 63000 & NA & 96900 & 96500 & 96700 & 0 \\
\hline $\mathrm{K}$ & $<875$ & 877 & 862 & $<<11$ & $<<911$ & NA & $<850$ & 887 & $<<887$ & $\mathrm{NA}$ & 25400 & 26000 & 25700 & +14 \\
\hline $\mathrm{La}$ & $<74.0$ & 505 & 524 & 486 & 505 & 4 & 446 & 467 & 456 & NA & $<244$ & 263 & $<263$ & NA \\
\hline $\mathrm{Li}$ & $<37.9$ & $<36.8$ & $<36.0$ & $<39.4$ & $<39.4$ & NA & $<36.8$ & $<36.8$ & $<36.8$ & NA & 14400 & 14500 & 14450 & -3 \\
\hline $\mathrm{Mg}$ & $<12.6$ & 598 & 602 & 586 & 595 & 1 & 609 & 607 & 608 & NA & 4880 & 4830 & 4855 & -7 \\
\hline $\mathrm{Mn}$ & $<5.41$ & 13800 & 13700 & 13500 & 13670 & 1 & 13700 & 13700 & 13700 & $\mathrm{NA}$ & 14100 & 14100 & 14100 & -3 \\
\hline Mo & $<271$ & $<263$ & $<257$ & $<282$ & $<282$ & NA & $<263$ & $<263$ & $<263$ & NA & $<894$ & $<857$ & $<894$ & NA \\
\hline $\mathrm{Na}$ & 660 & 16800 & 16600 & 16600 & 16670 & 1 & 16600 & 16500 & 16550 & $\mathrm{NA}$ & 83700 & 84500 & 84100 & -1 \\
\hline $\mathrm{Ni}$ & $<132$ & 2000 & 2000 & 1910 & 1970 & 3 & 1980 & 2000 & 1990 & NA & 7960 & 7800 & 7880 & -5 \\
\hline $\mathrm{P}$ & $<1,360$ & $<1320$ & $<1290$ & $<1410$ & $<1410$ & NA & $<1320$ & $<1320$ & $<1320$ & NA & $<4480$ & $<4290$ & $<4480$ & NA \\
\hline $\mathrm{Pb}$ & $<955$ & 2780 & 2770 & 2750 & 2770 & 1 & 2840 & 2960 & 2900 & NA & $<3150$ & $<3020$ & $<3150$ & $\mathrm{NA}$ \\
\hline $\mathrm{S}$ & $<401$ & $<389$ & $<380$ & $<417$ & $<417$ & NA & $\begin{array}{r}0.83 \\
\mathrm{mg} / \mathrm{L}\end{array}$ & $\begin{array}{r}0.85 \\
\mathrm{mg} / \mathrm{L}\end{array}$ & $\begin{array}{c}0.84 \\
\mathrm{mg} / \mathrm{L}\end{array}$ & $105 \%$ & $<1320$ & $<1270$ & $<1320$ & NA \\
\hline $\mathrm{Sb}$ & $<103$ & 242 & 209 & 281 & 244 & 15 & $\begin{array}{c}0.79 \\
\mathrm{mg} / \mathrm{L} \\
\end{array}$ & $\begin{array}{c}0.81 \\
\mathrm{mg} / \mathrm{L} \\
\end{array}$ & $\begin{array}{r}0.80 \\
\mathrm{mg} / \mathrm{L} \\
\end{array}$ & $100 \%$ & 633 & 513 & 573 & NA \\
\hline $\mathrm{Si}$ & $<93.8$ & 18200 & 18100 & 17800 & 18,000 & 1 & 18100 & 18100 & 18100 & NA & 226000 & 224000 & 225000 & 0 \\
\hline $\mathrm{Sn}$ & $<836$ & $<812$ & $<<793$ & $<870$ & $<870$ & NA & $<812$ & $<812$ & $<812$ & NA & $<2760$ & $<2640$ & $<2760$ & NA \\
\hline $\mathrm{Sr}$ & $<28.9$ & 911 & 932 & 913 & 919 & 1 & 919 & 927 & 923 & NA & 2340 & 2360 & 2350 & $>+100$ \\
\hline $\mathrm{Th}$ & $<32.5$ & $<31.6$ & $<30.8$ & $<33.8$ & $<33.8$ & NA & 0.80 & 0.80 & 0.80 & $100 \%$ & $<107$ & $<103$ & $<107$ & NA \\
\hline $\mathrm{Ti}$ & $<12.6$ & $<12.3$ & $<12.0$ & $<13.1$ & $<13.1$ & NA & $<12.3$ & $<12.3$ & $<12.3$ & $<12.3$ & 6940 & 6930 & 6935 & 0 \\
\hline $\mathrm{Tl}$ & $<186$ & $<181$ & $<176$ & $<193$ & $<193$ & NA & 0.86 & 0.86 & 0.86 & $107 \%$ & $<614$ & $<588$ & $<614$ & NA \\
\hline $\mathrm{U}$ & $<90.2$ & 194 & 225 & 164 & 194 & 16 & $\begin{array}{r}1.92 \\
\mathrm{mg} / \mathrm{L}\end{array}$ & $\begin{array}{c}2.46 \\
\mathrm{mg} / \mathrm{L}\end{array}$ & $\begin{array}{c}2.19 \\
\mathrm{mg} / \mathrm{L}\end{array}$ & $55 \%$ & $<298$ & $<286$ & $<298$ & NA \\
\hline $\mathrm{Zn}$ & $<18.0$ & 144 & 144 & 144 & 144 & 1 & 148 & 146 & 147 & NA & 180 & 200 & 190 & +19 \\
\hline $\mathrm{Zr}$ & \multicolumn{14}{|c|}{ Not reported-Zr crucibles were used for these fusion digestions } \\
\hline $\begin{array}{l}\text { a. } \\
\text { b. }\end{array}$ & \multicolumn{14}{|c|}{$\begin{array}{l}\text { Elemental analysis concentrations of slurry simulant reported on wet slurry basis; The AY-102/C-106 simulant contained } 23.59 \pm 0.03 \% \text { solids } \\
\text { on oxide basis after heating at } 1100{ }^{\circ} \mathrm{C} \text {. Elemental analysis concentrations of the LCS glass reported on dry powdered glass basis. } \\
\text { Concentrations of spiked elements reported in } \mathrm{mg} / \mathrm{L} \text { to facilitate comparison with the theoretical concentrations. Ag, Cd, } \mathrm{S}, \mathrm{Sb}, \mathrm{Th} \text {, and } \mathrm{Tl} \text { were } \\
\text { spiked at } 0.8 \mathrm{mg} / \mathrm{L} \text { of the solutions after digestion; } \mathrm{U} \text { was spiked at } 4.0 \mathrm{mg} / \mathrm{L} \text { of the solutions after digestion. }\end{array}$} \\
\hline
\end{tabular}


WSRC-TR-2005-00169, REVISION 0 SRNL-RPP-2005-00023, REVISION 0

Table 3-7. Elemental Analysis of AY-102/C-106 Simulant WTP Sample Type: HLW-2A Digestion Method: $\mathrm{CsOH}$ in Nickel Crucible

\begin{tabular}{|c|c|c|c|c|c|c|c|c|c|c|c|c|c|c|}
\hline Element $^{a}$ & $(\mu \mathrm{g} / \mathrm{g})$ & $\begin{array}{c}\text { Trial } \\
1 \\
(\mu \mathrm{g} / \mathrm{g})\end{array}$ & $\begin{array}{c}\text { Trial } \\
2 \\
(\mu \mathrm{g} / \mathrm{g})\end{array}$ & $\begin{array}{c}\text { Trial } \\
3 \\
(\mu \mathrm{g} / \mathrm{g})\end{array}$ & $(\mu \mathrm{g} / \mathrm{g})$ & (\%) & $\begin{array}{c}\text { Spike }^{\mathrm{b} .} \\
1 \\
(\mu \mathrm{g} / \mathrm{g})\end{array}$ & $\begin{array}{c}\text { Spike }^{\mathrm{b} .} \\
2 \\
(\mu \mathrm{g} / \mathrm{g})\end{array}$ & $\begin{array}{l}\text { Spike } \\
\text { Avg. } \\
(\mu \mathrm{g} / \mathrm{g})\end{array}$ & $\begin{array}{c}\text { Spike } \\
\text { Recov. } \\
(\%)\end{array}$ & $\begin{array}{c}\text { LCS } \\
\text { Tria1 } \\
1 \\
(\mu \mathrm{g} / \mathrm{g})\end{array}$ & $\begin{array}{c}\text { LCS } \\
\text { Trial } \\
2 \\
(\mu \mathrm{g} / \mathrm{g})\end{array}$ & $\begin{array}{l}\text { LCS } \\
\text { Avg. } \\
(\mu \mathrm{g} / \mathrm{g})\end{array}$ & Error \\
\hline $\mathrm{Ag}$ & $<17.2$ & 567 & 467 & 373 & 469 & 21 & $\begin{array}{c}0.14 \\
\mathrm{mg} / \mathrm{L}\end{array}$ & $\begin{array}{c}0.22 \\
\mathrm{mg} / \mathrm{L}\end{array}$ & $\begin{array}{c}0.18 \\
\mathrm{mg} / \mathrm{L}\end{array}$ & $23 \%$ & $<56.0$ & $<54.0$ & $<54.0$ & NA \\
\hline $\mathrm{Al}$ & $<156$ & 17500 & 17000 & 16900 & 17130 & 2 & 17600 & 17500 & 17555 & NA & 23500 & 22100 & 22800 & -15 \\
\hline B & $<61.9$ & $<62.6$ & $<45.7$ & $<49.5$ & $<62.6$ & $\mathrm{NA}$ & $<62.6$ & $<62.6$ & $<62.6$ & NA & 26200 & 24600 & 25400 & -6 \\
\hline $\mathrm{Ba}$ & $<13.8$ & 585 & 556 & 574 & 572 & 3 & 585 & 596 & 590 & $\mathrm{NA}$ & 916 & 855 & 885 & +12 \\
\hline $\mathrm{Ca}$ & $<55.0$ & 2440 & 2270 & 2330 & 2350 & 4 & 2540 & 2430 & 2485 & NA & 10800 & 10100 & 10,450 & +2 \\
\hline $\mathrm{Cd}$ & $<36.1$ & 79.5 & 86.7 & 82.1 & 82.8 & 4 & $\begin{array}{r}0.79 \\
\mathrm{mg} / \mathrm{L}\end{array}$ & $\begin{array}{c}0.79 \\
\mathrm{mg} / \mathrm{L}\end{array}$ & $\begin{array}{c}0.79 \\
\mathrm{mg} / \mathrm{L}\end{array}$ & $99 \%$ & $<118$ & $<113$ & $<118$ & NA \\
\hline $\mathrm{Ce}$ & $<210$ & 580 & 594 & 539 & 571 & 5 & 633 & 686 & 660 & NA & $<683$ & $<659$ & $<683$ & NA \\
\hline $\mathrm{Cr}$ & $<63.6$ & 888 & 894 & 868 & 883 & 2 & 870 & 884 & 877 & $\mathrm{NA}$ & 732 & 710 & 721 & +13 \\
\hline $\mathrm{Cu}$ & $<20.6$ & 8010 & 139 & 151 & 2770 & 164 & 7920 & 7880 & 7900 & NA & $<67.2$ & $<64.8$ & $<67.2$ & NA \\
\hline $\mathrm{Fe}$ & $<87.7$ & 65500 & 63300 & 63000 & 63900 & 2 & 64900 & 65500 & 65200 & NA & 104000 & 97700 & 100850 & +3 \\
\hline $\mathrm{K}$ & $<834$ & 897 & 772 & $<667$ & $<897$ & NA & $<843$ & $<843$ & $<843$ & $\mathrm{NA}$ & 24500 & 23400 & 23950 & +6 \\
\hline $\mathrm{La}$ & $<70.5$ & 497 & 491 & 490 & 493 & 1 & 500 & 501 & 500 & NA & $<230$ & $<221$ & $<230$ & NA \\
\hline $\mathrm{Li}$ & $<36.1$ & $<36.5$ & $<26.6$ & $<28.9$ & $<36.5$ & NA & $<36.5$ & $<36.5$ & $<36.5$ & NA & 14900 & 13700 & 14300 & -4 \\
\hline $\mathrm{Mg}$ & $<12.0$ & 655 & 624 & 640 & 640 & 2 & 674 & 680 & 677 & $\mathrm{NA}$ & 5340 & 5050 & 5195 & 0 \\
\hline $\mathrm{Mn}$ & $<5.16$ & 14800 & 13700 & 13900 & 14130 & 4 & 14700 & 14800 & 14750 & $\mathrm{NA}$ & 15300 & 14400 & 14850 & +2 \\
\hline Mo & $<258$ & $<261$ & 220 & 222 & $<261$ & NA & 262 & 268 & 263 & NA & $<840$ & $<810$ & $<810$ & NA \\
\hline $\mathrm{Na}$ & $<373$ & 16600 & 15800 & 15900 & 16100 & 3 & 16500 & 16400 & 15450 & NA & 85800 & 79500 & 82650 & -3 \\
\hline $\mathrm{Ni}$ & \multicolumn{14}{|c|}{ Not reported: Ni crucible used in digestion } \\
\hline $\mathrm{P}$ & $<1290$ & $<1310$ & 999 & $<1030$ & $<1310$ & NA & $<1310$ & $<1310$ & $<1310$ & NA & $<4210$ & $<4060$ & $<4210$ & NA \\
\hline $\mathrm{Pb}$ & $<<909$ & 3140 & 2800 & 2890 & 2940 & 6 & 2990 & 2910 & 2950 & NA & $<2960$ & $<2860$ & $<2960$ & NA \\
\hline S & $<382$ & $<386$ & 570 & $<305$ & $<570$ & NA & $\begin{array}{r}0.92 \\
\mathrm{mg} / \mathrm{L}\end{array}$ & $\begin{array}{r}1.00 \\
\mathrm{mg} / \mathrm{L}\end{array}$ & $\begin{array}{c}0.96 \\
\mathrm{mg} / \mathrm{L}\end{array}$ & $120 \%$ & $<1240$ & $<1200$ & $<1200$ & NA \\
\hline $\mathrm{Sb}$ & $<98.0$ & 275 & 272 & 261 & 269 & 3 & $\begin{array}{c}0.77 \\
\mathrm{mg} / \mathrm{L}\end{array}$ & $\begin{array}{r}0.82 \\
\mathrm{mg} / \mathrm{L} \\
\end{array}$ & $\begin{array}{r}0.79 \\
\mathrm{mg} / \mathrm{L}\end{array}$ & $99 \%$ & 600 & 645 & 622 & NA \\
\hline $\mathrm{Si}$ & $<89.4$ & 18700 & 18200 & 18000 & 18300 & 2 & 18700 & 18800 & 18750 & NA & 239000 & 229000 & 234000 & +4 \\
\hline $\mathrm{Sn}$ & $<796$ & $<805$ & $<<587$ & $<636$ & $<805$ & NA & $<805$ & $<805$ & $<805$ & NA & $<2590$ & $<2500$ & $<2590$ & NA \\
\hline $\mathrm{Sr}$ & $<27.5$ & 943 & 887 & 904 & 911 & 3 & 974 & 953 & 963 & NA & 2340 & 2190 & 2265 & $>100$ \\
\hline Th & $<30.9$ & $<31.3$ & $<22.8$ & $<24.7$ & $<31.3$ & NA & $\begin{array}{r}0.72 \\
\mathrm{mg} / \mathrm{L}\end{array}$ & $\begin{array}{r}0.75 \\
\mathrm{mg} / \mathrm{L}\end{array}$ & $\begin{array}{r}0.73 \\
\mathrm{mg} / \mathrm{L}\end{array}$ & $91 \%$ & $<101$ & $<97.2$ & $<101$ & NA \\
\hline $\mathrm{Ti}$ & $<12.0$ & $<12.2$ & $<8.88$ & $<9.62$ & $<12.2$ & NA & $<12.2$ & $<12.2$ & $<12.2$ & NA & 7150 & 6710 & 6930 & 0 \\
\hline $\mathrm{Tl}$ & $<177$ & $<179$ & $<131$ & $<142$ & $<179$ & NA & $\begin{array}{c}0.80 \\
\mathrm{mg} / \mathrm{L} \\
\end{array}$ & $\begin{array}{r}0.83 \\
\mathrm{mg} / \mathrm{L} \\
\end{array}$ & $\begin{array}{c}0.81 \\
\mathrm{mg} / \mathrm{L} \\
\end{array}$ & $101 \%$ & $<577$ & $<556$ & $<577$ & NA \\
\hline $\mathrm{U}$ & $<85.9$ & 131 & 121 & 115 & 122 & 7 & $\begin{array}{c}2.39 \\
\mathrm{mg} / \mathrm{L}\end{array}$ & $\begin{array}{c}2.96 \\
\mathrm{mg} / \mathrm{L}\end{array}$ & $\begin{array}{c}2.68 \\
\mathrm{mg} / \mathrm{L}\end{array}$ & $67 \%$ & $<280$ & $<270$ & $<280$ & NA \\
\hline $\mathrm{Zn}$ & $<17.2$ & 204 & 176 & 225 & 202 & 12 & 202 & 208 & 205 & NA & 338 & 297 & 318 & +100 \\
\hline $\mathrm{Zr}$ & $<24.1$ & 78.6 & 76.6 & 60.3 & 71.8 & 14 & 143 & 144 & 144 & NA & 848 & 821 & 835 & -13 \\
\hline b. & \multicolumn{14}{|c|}{$\begin{array}{l}\text { Elemental analysis concentrations of slurry simulant reported on wet slurry basis; The AY-102/C-106 simulant contained } 23.59 \pm 0.03 \% \\
\text { solids on oxide basis after heating at } 1100^{\circ} \mathrm{C} \text {. Elemental analysis concentrations of the LCS glass reported on dry powdered glass basis. } \\
\text { Concentrations of spiked elements reported in } \mathrm{mg} / \mathrm{L} \text { to facilitate comparison with the theoretical concentrations. Ag, } \mathrm{Cd}, \mathrm{S}, \mathrm{Sb}, \mathrm{Th}, \text { and } \mathrm{Tl} \\
\text { were spiked at } 0.8 \mathrm{mg} / \mathrm{L} \text { of the solutions after digestion; } \mathrm{U} \text { was spiked at } 4.0 \mathrm{mg} / \mathrm{L} \text { of the solutions after digestion. }\end{array}$} \\
\hline
\end{tabular}




\section{WSRC-TR-2005-00169, REVISION 0 SRNL-RPP-2005-00023, REVISION 0}

Table 3-8. Elemental Analysis of AY-102/C-106 Simulant WTP Sample Type: HLW-2A Digestion Method: $\mathrm{CsOH} / \mathrm{Cs}_{2} \mathrm{CO}_{3}$ Fusion in Pt crucibles

\begin{tabular}{|c|c|c|c|c|c|c|c|c|c|c|c|c|c|c|}
\hline Element $^{\mathrm{a}}$ & $(\mu \mathrm{g} / \mathrm{g})$ & $\begin{array}{c}\text { Trial } \\
1 \\
(\mu \mathrm{g} / \mathrm{g})\end{array}$ & $\begin{array}{c}\text { Trial } \\
2 \\
(\mu \mathrm{g} / \mathrm{g})\end{array}$ & $\begin{array}{c}\text { Trial } \\
3 \\
(\mu \mathrm{g} / \mathrm{g})\end{array}$ & $\begin{array}{l}\text { Avg. } \\
(\mu \mathrm{g} / \mathrm{g})\end{array}$ & $\begin{array}{l}\text { RSD } \\
(\%) \\
\end{array}$ & $\begin{array}{c}\text { Spike } \\
1 \\
(\mu g / g)\end{array}$ & $\begin{array}{c}\text { Spike }^{\mathrm{b}} \\
2 \\
(\mu \mathrm{g} / \mathrm{g})\end{array}$ & $\begin{array}{c}\text { Spike }^{\text {b. }} \\
\text { Avg. } \\
\text { ( } \mu g / g)\end{array}$ & $\begin{array}{c}\text { Spike }^{\text {b. }} \\
\text { Recovery } \\
(\%)\end{array}$ & $\begin{array}{c}\text { LCS } \\
\text { Tria1 } \\
1 \\
(\mu \mathrm{g} / \mathrm{g})\end{array}$ & $\begin{array}{c}\text { LCS } \\
\text { Trial } \\
2 \\
(\mu \mathrm{g} / \mathrm{g}) \\
\end{array}$ & $\begin{array}{l}\text { LCS } \\
\text { Avg. } \\
(\mu \mathrm{g} / \mathrm{g})\end{array}$ & Error \\
\hline $\mathrm{Ag}$ & $<17.2$ & 364 & 604 & 899 & 622 & $43 \%$ & $\begin{array}{c}0.48 \\
\mathrm{mg} / \mathrm{L}\end{array}$ & $\begin{array}{c}0.40 \\
\mathrm{mg} / \mathrm{L}\end{array}$ & $\begin{array}{c}0.44 \\
\mathrm{mg} / \mathrm{L}\end{array}$ & $55 \%$ & 416 & 448 & 432 & NA \\
\hline $\mathrm{Al}$ & $<156$ & 17100 & 17300 & 17300 & 17,200 & 1 & 17000 & 16900 & 16950 & NA & 22700 & 22600 & 22650 & -9 \\
\hline $\mathrm{B}$ & $<61.9$ & $<54.7$ & $<57.7$ & $<62.1$ & $<62$ & NA & $<54.7$ & $<54.7$ & $<54.7$ & NA & 25300 & 25000 & 25150 & -7 \\
\hline $\mathrm{Ba}$ & 20.8 & 616 & 617 & 626 & 620 & 1 & 610 & 600 & 605 & NA & 914 & 910 & 912 & +15 \\
\hline $\mathrm{Ca}$ & $<55.0$ & 2340 & 2290 & 2350 & 2330 & 1 & 2400 & 2380 & 2390 & NA & 10500 & 10300 & 10400 & +2 \\
\hline $\mathrm{Cd}$ & $<36.1$ & 85.5 & 69.6 & 81.8 & 79.0 & 10 & $\begin{array}{c}0.78 \\
\mathrm{mg} / \mathrm{L}\end{array}$ & $\begin{array}{c}0.78 \\
\mathrm{mg} / \mathrm{L}\end{array}$ & $\begin{array}{c}0.78 \\
\mathrm{mg} / \mathrm{L}\end{array}$ & $98 \%$ & $<118$ & $<117$ & $<118$ & NA \\
\hline $\mathrm{Ce}$ & $<210$ & 450 & 543 & 554 & 517 & 11 & 488 & 480 & 484 & NA & $<685$ & $<680$ & $<685$ & NA \\
\hline $\mathrm{Cr}$ & $<63.6$ & 855 & 851 & 874 & 860 & 1 & 854 & 830 & 842 & NA & 640 & 676 & 658 & +3 \\
\hline $\mathrm{Cu}$ & $<20.6$ & 127 & 108 & 134 & 123 & 11 & 136 & 134 & 135 & NA & $<67.4$ & $<66.9$ & $<67.4$ & NA \\
\hline $\mathrm{Fe}$ & $<87.7$ & 64800 & 64300 & 64900 & 64700 & 1 & 64200 & 63800 & 64000 & NA & 99900 & 99100 & 99500 & +2 \\
\hline $\mathrm{K}$ & $<834$ & $<>737$ & $<>778$ & $<836$ & $<836$ & $\mathrm{NA}$ & $<>737$ & $<>737$ & $<737$ & NA & 23000 & 23600 & 23300 & +3 \\
\hline $\mathrm{La}$ & $<70.5$ & 496 & 521 & 522 & 513 & 3 & 502 & 495 & 499 & NA & $<230$ & $<228$ & $<230$ & NA \\
\hline $\mathrm{Li}$ & $<36.1$ & $<31.9$ & $<33.7$ & $<36.2$ & $<36.2$ & NA & $<31.9$ & $<31.9$ & $<31.9$ & NA & 14200 & 14000 & 14100 & -5 \\
\hline $\mathrm{Mg}$ & $<12.0$ & 633 & 627 & 651 & 637 & NA & 648 & 643 & 645 & NA & 5190 & 5130 & 5160 & -1 \\
\hline $\mathrm{Mn}$ & $<5.16$ & 14300 & 14200 & 14400 & 14300 & 1 & 14200 & 14100 & 14150 & NA & 14700 & 14600 & 14650 & 0 \\
\hline Mo & $<258$ & $<228$ & $<241$ & $<259$ & $<259$ & NA & $<228$ & $<228$ & $<228$ & NA & $<842$ & $<836$ & $<842$ & NA \\
\hline $\mathrm{Na}$ & $<373$ & 16100 & 16100 & 16200 & 16100 & 1 & 16200 & 16100 & 16100 & NA & 81600 & 81100 & 81350 & -5 \\
\hline $\mathrm{Ni}$ & $<125$ & 1770 & 1880 & 1930 & 1860 & 4 & 1720 & 1750 & 1735 & NA & 8230 & 7640 & 7935 & -4 \\
\hline $\mathrm{P}$ & $<1290$ & $<1140$ & 1280 & $<1300$ & NA & NA & 1400 & $<1140$ & NA & $\mathrm{NA}$ & $<4220$ & $<4180$ & $<4220$ & NA \\
\hline $\mathrm{Pb}$ & $<909$ & 2630 & 2740 & 2380 & 2580 & 7 & 2810 & 2520 & 2665 & NA & $<2970$ & $<2950$ & $<2970$ & NA \\
\hline $\mathrm{S}$ & $<382$ & $<337$ & $<356$ & $<383$ & $<383$ & NA & 0.92 & 0.87 & 0.90 & $112 \%$ & $<1250$ & $<1240$ & $<1240$ & NA \\
\hline $\mathrm{Sb}$ & $<98.0$ & 239 & 233 & 249 & 240 & 3 & $\begin{array}{r}0.81 \\
\mathrm{mg} / \mathrm{L} \\
\end{array}$ & $\begin{array}{r}0.78 \\
\mathrm{mg} / \mathrm{L} \\
\end{array}$ & $\begin{array}{r}0.80 \\
\mathrm{mg} / \mathrm{L} \\
\end{array}$ & $100 \%$ & 469 & 502 & 486 & NA \\
\hline $\mathrm{Si}$ & $<89.4$ & 17900 & 17900 & 18500 & 18100 & 2 & 17800 & 17600 & 17700 & NA & 227000 & 225000 & 226000 & +1 \\
\hline $\mathrm{Sn}$ & $<796$ & $<704$ & $<743$ & $<798$ & $<798$ & NA & $<>704$ & $<704$ & $<704$ & NA & $<2600$ & $<2580$ & $<2600$ & NA \\
\hline $\mathrm{Sr}$ & $<27.5$ & 945 & 931 & 935 & 937 & 1 & 957 & 956 & 956 & NA & 2330 & 2300 & 2315 & $>+100$ \\
\hline $\mathrm{Th}$ & $<30.9$ & $<27.4$ & $<28.9$ & $<31.0$ & $<31.0$ & NA & $\begin{array}{r}0.75 \\
\mathrm{mg} / \mathrm{L}\end{array}$ & $\begin{array}{r}0.75 \\
\mathrm{mg} / \mathrm{L}\end{array}$ & $\begin{array}{r}0.75 \\
\mathrm{mg} / \mathrm{L}\end{array}$ & $93 \%$ & $<101$ & $<100$ & $<100$ & NA \\
\hline $\mathrm{Ti}$ & $<12.0$ & $<10.6$ & $<11.2$ & $<12.1$ & $<12.1$ & NA & $<10.6$ & $<10.6$ & $<10.6$ & NA & 7000 & 6970 & 6985 & +1 \\
\hline $\mathrm{Tl}$ & $<177$ & $<157$ & $<165$ & $<178$ & $<178$ & NA & $\begin{array}{r}0.85 \\
\mathrm{mg} / \mathrm{L} \\
\end{array}$ & $\begin{array}{c}0.84 \\
\mathrm{mg} / \mathrm{L}\end{array}$ & $\begin{array}{c}0.84 \\
\mathrm{mg} / \mathrm{L}\end{array}$ & $105 \%$ & $<578$ & $<574$ & $<574$ & NA \\
\hline $\mathrm{U}$ & $<85.9$ & 132 & 120 & 134 & 129 & 6 & $\begin{array}{r}2.79 \\
\mathrm{mg} / \mathrm{L}\end{array}$ & $\begin{array}{c}3.16 \\
\mathrm{mg} / \mathrm{L}\end{array}$ & $\begin{array}{r}2.98 \\
\mathrm{mg} / \mathrm{L}\end{array}$ & $74 \%$ & $<281$ & 330 & NA & NA \\
\hline $\mathrm{Zn}$ & $<17.2$ & 145 & 134 & 194 & 158 & 20 & 147 & 143 & 145 & NA & 286 & 230 & 258 & +61 \\
\hline $\mathrm{Zr}$ & $<24.1$ & 184 & 361 & 433 & 326 & 39 & 297 & 281 & 289 & NA & 1010 & 1000 & 1005 & +5 \\
\hline $\begin{array}{l}\text { a. } \\
\text { b. }\end{array}$ & \multicolumn{14}{|c|}{$\begin{array}{l}\text { Elemental analysis concentrations of slurry simulant reported on wet slurry basis; The AY-102/C-106 simulant contained } 23.59 \pm 0.03 \% \text { solids } \\
\text { on oxide basis after heating at } 1100{ }^{\circ} \mathrm{C} \text {. The elemental analysis concentration of the LCS glass reported on dry powdered glass basis. } \\
\text { Concentrations of spiked elements reported in } \mathrm{mg} / \mathrm{L} \text { to facilitate comparison with the theoretical concentrations. Ag, } \mathrm{Cd}, \mathrm{S}, \mathrm{Sb}, \mathrm{Th} \text {, and } \mathrm{Tl} \mathrm{were} \\
\text { spiked at } 0.8 \mathrm{mg} / \mathrm{L} \text { of the solutions after digestion; U was spiked at } 4.0 \mathrm{mg} / \mathrm{L} \text { of the solutions after digestion. }\end{array}$} \\
\hline
\end{tabular}


WSRC-TR-2005-00169, REVISION 0

SRNL-RPP-2005-00023, REVISION 0

Table 3-9. Elemental Analysis of AY-102/C-106 Melter Feed as Dried Slurry WTP Sample Type: HLW-2B -

Digestion Method: Cesium Carbonate Fusion in Pt Crucibles

\begin{tabular}{|c|c|c|c|c|c|c|c|c|c|c|c|c|}
\hline Element $^{\mathrm{a}}$ & $(\mu \mathrm{g} / \mathrm{g})$ & $\begin{array}{c}\text { Trial } \\
1\end{array}$ & $\begin{array}{c}\text { Trial } \\
2\end{array}$ & $\begin{array}{c}\text { Trial } \\
\mathbf{3}\end{array}$ & $\begin{array}{c}\text { Trial } \\
4\end{array}$ & $(\mu \mathrm{g} / \mathrm{g})$ & RSD & $\begin{array}{c}\text { Avg. } \\
\text { Spike } \\
\text { Recovery } \\
\text { (From } \\
\text { Trials 3 } \\
\text { and 4) } \\
(\%) \\
\end{array}$ & $\begin{array}{c}\text { LCS } \\
\text { Tria1 } \\
1\end{array}$ & $\begin{array}{c}\text { LCS } \\
\text { Trial } \\
2\end{array}$ & $\begin{array}{l}\text { LCS } \\
\text { Avg. }\end{array}$ & Error \\
\hline $\mathrm{Ag}$ & $<34.4$ & 636 & 526 & 732 & 677 & 643 & 14 & NA & 122 & $<88.7$ & $<122$ & NA \\
\hline $\mathrm{Al}$ & $<313$ & 10200 & 10500 & 10500 & 10500 & 10400 & 1 & NA & 23600 & 23600 & 23600 & -6 \\
\hline $\mathrm{B}$ & $<124$ & 10900 & 10900 & 10700 & 10900 & 10900 & 1 & NA & 23600 & 23800 & 23700 & -12 \\
\hline $\mathrm{Ba}$ & 43.6 & 343 & 361 & 346 & 358 & 352 & 3 & NA & 921 & 945 & 933 & +18 \\
\hline $\mathrm{Ca}$ & $<110$ & 1450 & 1340 & 1340 & 1420 & 1390 & 4 & NA & 10200 & 10100 & 10200 & +4 \\
\hline $\mathrm{Cd}$ & $<72.2$ & $<53.1$ & $<69.7$ & $<61.9$ & $<61.0$ & $<69.7$ & NA & NA & $<176$ & $<186$ & $<186$ & NA \\
\hline $\mathrm{Ce}$ & $<419$ & 624 & 736 & 646 & 662 & 667 & 7 & NA & $<1020$ & $<1080$ & $<1080$ & NA \\
\hline $\mathrm{Cr}$ & $<66.2$ & 416 & 382 & 410 & 415 & 406 & 4 & NA & 592 & 673 & 632 & NA \\
\hline $\mathrm{Cu}$ & $<41.3$ & 105 & 111 & 101 & 103 & 105 & 4 & NA & $<101$ & $<106$ & $<106$ & NA \\
\hline $\mathrm{Fe}$ & $<14.2$ & 36400 & 37200 & 36500 & 36800 & 36700 & 1 & NA & 99000 & 99200 & 99100 & +1 \\
\hline $\mathrm{K}$ & $<1670$ & 2600 & 2800 & 2710 & 2680 & 2700 & 3 & NA & 23300 & 24800 & 24000 & +6 \\
\hline $\mathrm{La}$ & $<141$ & 358 & 397 & 369 & 381 & 376 & 4 & NA & $<344$ & $<364$ & $<364$ & NA \\
\hline $\mathrm{Li}$ & $<72.2$ & 4330 & 4450 & 4440 & 4460 & 4420 & 1 & NA & 14700 & 14700 & 14700 & -1 \\
\hline $\mathrm{Mg}$ & $<24.1$ & 400 & 404 & 389 & 396 & 397 & 2 & NA & 5100 & 5170 & 5140 & -1 \\
\hline $\mathrm{Mn}$ & $<10.3$ & 7920 & 8110 & 7950 & 8030 & 8000 & 1 & NA & 14400 & 14500 & 14400 & -1 \\
\hline Mo & $<306$ & $<293$ & $<228$ & $<263$ & $<259$ & $<293$ & NA & NA & $<748$ & $<791$ & $<791$ & NA \\
\hline $\mathrm{Na}$ & $<746$ & 30300 & 30800 & 30400 & 30600 & 30500 & 1 & NA & 80300 & 80100 & 80200 & -6 \\
\hline $\mathrm{Ni}$ & $<99.7$ & 1190 & 1258 & 1210 & 1190 & 1210 & 3 & NA & 8190 & 8510 & 8350 & -1 \\
\hline $\mathrm{P}$ & $<2580$ & $<2470$ & $<1920$ & $<2220$ & $<2180$ & $<2470$ & NA & NA & $<6300$ & $<6660$ & $<6660$ & NA \\
\hline $\mathrm{Pb}$ & $<1820$ & $<1700$ & $<1350$ & 1730 & $<1700$ & $<1700$ & NA & NA & $<4440$ & $<4690$ & $<4690$ & NA \\
\hline $\mathrm{Sb}$ & $<196$ & 191 & 262 & 215 & 250 & 230 & 14 & NA & 534 & 814 & 674 & NA \\
\hline $\mathrm{Si}$ & $<179$ & 78500 & 84800 & 83200 & 84400 & 82700 & 4 & NA & 222000 & 225000 & 22400 & 0 \\
\hline $\mathrm{Sn}$ & $<1590$ & $<1170$ & $<1530$ & $<1370$ & $<1340$ & $<1530$ & NA & NA & $<3890$ & $<4110$ & $<4110$ & NA \\
\hline $\mathrm{Sr}$ & $<55.0$ & 545 & 537 & 519 & 542 & 536 & 2 & NA & 2100 & 2140 & 2120 & $>100$ \\
\hline $\mathrm{Ti}$ & $<6.32$ & 18.8 & 15.7 & 17.5 & 18.0 & 17.5 & 8 & NA & 6980 & 7000 & 6990 & +1 \\
\hline $\mathrm{Y}$ & $<344$ & $<253$ & $<331$ & $\begin{array}{r}1.94 \\
\mathrm{mg} / \mathrm{L} \\
(97 \% \\
\text { spike } \\
\text { recovery) }\end{array}$ & $\begin{array}{r}1.94 \\
\mathrm{mg} / \mathrm{L} \\
(97 \% \\
\text { spike } \\
\text { recovery) }\end{array}$ & 1.94 & 0 & $97 \%$ & $<839$ & $<887$ & $<887$ & NA \\
\hline $\mathrm{Zn}$ & $<34.4$ & 2961 & 3042 & 2960 & 2990 & 2990 & 1 & NA & 199 & 210 & 204 & +28 \\
\hline $\mathrm{Zr}$ & $<18.3$ & 492 & 531 & 515 & 514 & 513 & 3 & NA & 864 & 889 & 876 & -9 \\
\hline b. & \multicolumn{12}{|c|}{$\begin{array}{l}\text { Elemental analysis concentrations of slurry simulant reported on wet slurry basis; The AY-102/C-106 Melter Feed simulant } \\
\text { contained } 36.92 \pm 0.05 \% \text { solids on oxide basis after heating at } 1100{ }^{\circ} \mathrm{C} \text {. Elemental analysis concentrations of the LCS glass } \\
\text { reported on dry powdered glass basis. } \\
\text { Concentration of spiked Y reported in } \mathrm{mg} / \mathrm{L} \text { to facilitate comparison with the theoretical concentration. Y was spiked into } \\
\text { sample before the digestion so that the theoretical concentration was } 2.0 \mathrm{mg} / \mathrm{L} \text {. }\end{array}$} \\
\hline
\end{tabular}


WSRC-TR-2005-00169, REVISION 0

SRNL-RPP-2005-00023, REVISION 0

Table 3-10. Elemental Analysis of AY-102/C-106 Melter Feed Vitrified into Glass WTP Sample Type: HLW-2B -

Digestion Method: Cesium Carbonate Fusion in Pt Crucibles

\begin{tabular}{|c|c|c|c|c|c|c|c|c|c|c|c|c|c|}
\hline Element $^{\mathrm{a}}$ & $(\mu \mathrm{g} / \mathrm{g})$ & Trial 1 & $\begin{array}{c}\text { Trial } \\
2\end{array}$ & $\begin{array}{c}\text { Trial } \\
\mathbf{3}\end{array}$ & $\begin{array}{c}\text { Trial } \\
4\end{array}$ & $\begin{array}{c}\text { Trial } \\
5\end{array}$ & $\begin{array}{c}\text { Avg. } \\
\text { of } \\
\text { Trials } \\
1-5 \\
\\
(\mu \mathrm{g} / \mathrm{g})\end{array}$ & (\%) & $\begin{array}{c}\text { Avg. } \\
\text { Spike }^{\text {b. }} \\
\text { Recovery } \\
\text { (From } \\
\text { Trials } 4 \\
\text { and 5) } \\
(\%)\end{array}$ & $\begin{array}{c}\text { LCS } \\
\text { Tria1 } \\
1\end{array}$ & $\begin{array}{l}\text { LCS } \\
\text { Trial } \\
2\end{array}$ & $\begin{array}{l}\text { LCS } \\
\text { Avg. }\end{array}$ & Error \\
\hline $\mathrm{Ag}$ & $<19.8$ & 528 & 499 & 543 & 600 & 596 & 553 & 8 & NA & 125 & $<57.7$ & $<57.7$ & NA \\
\hline $\mathrm{Al}$ & $<180$ & 11200 & 11300 & 11300 & 11100 & 11100 & 11200 & 1 & NA & 23700 & 23900 & 23800 & -5 \\
\hline B & $<71.3$ & 10700 & 11100 & 10600 & 10800 & 11100 & 10900 & 2 & $\mathrm{NA}$ & 24700 & 24600 & 24600 & -8 \\
\hline $\mathrm{Ba}$ & 35.2 & 369 & 381 & 371 & 364 & 358 & 369 & 2 & $\mathrm{NA}$ & 928 & 946 & 937 & \\
\hline $\mathrm{Ca}$ & $<63.4$ & 1380 & 1390 & 1400 & 1360 & 1370 & 1380 & 1 & NA & 10500 & 10500 & 10500 & +3 \\
\hline $\mathrm{Cd}$ & $<41.6$ & 46.8 & 49.8 & 46.1 & 45.0 & 44.6 & 46.5 & 4 & $\mathrm{NA}$ & $<115$ & $<121$ & $<121$ & $<121$ \\
\hline $\mathrm{Ce}$ & $<242$ & 614 & 720 & 648 & 589 & 578 & 630 & 9 & $\mathrm{NA}$ & $<666$ & $<703$ & $<703$ & NA \\
\hline $\mathrm{Cr}$ & $<38.1$ & 429 & 430 & 423 & 451 & 433 & 433 & 2 & $\mathrm{NA}$ & 679 & 578 & 628 & -2 \\
\hline $\mathrm{Cu}$ & $<23.8$ & 91.1 & 94.3 & 92.8 & 90.6 & 87.8 & 91.3 & 3 & NA & 67.1 & $<69.2$ & $<69.2$ & NA \\
\hline $\mathrm{Fe}$ & $<8.20$ & 37100 & 37400 & 37000 & 36900 & 36700 & 37100 & 1 & NA & 99900 & 100000 & 100000 & +2 \\
\hline $\mathrm{La}$ & $<81.2$ & 359 & 390 & 372 & 357 & 354 & 366 & 4 & NA & $<224$ & $<236$ & $<236$ & NA \\
\hline $\mathrm{Li}$ & $<41.6$ & 4520 & 4550 & 4580 & 4450 & 4480 & 4520 & 1 & NA & 15100 & 15200 & 15200 & +2 \\
\hline $\mathrm{Mg}$ & $<13.9$ & 418 & 416 & 429 & 408 & 412 & 417 & 2 & NA & 5200 & 5260 & 5240 & +1 \\
\hline $\mathrm{Mn}$ & $<5.94$ & 8120 & 8190 & 8200 & 8040 & 8040 & 8120 & 1 & $\mathrm{NA}$ & 14600 & 14700 & 14600 & 0 \\
\hline Mo & $<177$ & $<161$ & $<202$ & $<170$ & $<177$ & $<141$ & $<202$ & NA & NA & $<486$ & $<514$ & $<514$ & NA \\
\hline $\mathrm{Na}$ & 524 & 32400 & 33100 & 32400 & 31900 & 31700 & 32300 & 2 & NA & 85500 & 85600 & 85600 & 1 \\
\hline $\mathrm{Ni}$ & $<57.4$ & 1160 & 1190 & 1210 & 1210 & 1180 & 1190 & 2 & NA & 8330 & 8400 & 8360 & 1 \\
\hline $\mathrm{P}$ & $<1490$ & $<1360$ & $<1700$ & $<1430$ & $<1490$ & $<1190$ & $<1490$ & NA & NA & $<4100$ & $<4330$ & $<4330$ & NA \\
\hline $\mathrm{Pb}$ & $<1050$ & $<958$ & $<1200$ & $<1010$ & $<1050$ & $<839$ & $<1050$ & NA & $\mathrm{NA}$ & $<2890$ & $<3050$ & $<3050$ & $\mathrm{NA}$ \\
\hline $\mathrm{Sb}$ & $<113$ & 226 & 287 & 249 & 224 & 182 & 234 & 16 & NA & 581 & 709 & 645 & NA \\
\hline $\mathrm{Si}$ & $<103$ & 85400 & 85900 & 85900 & 83900 & 83900 & 85000 & 1 & NA & 230000 & 232000 & 231000 & +3 \\
\hline $\mathrm{Sn}$ & $<917$ & $<<839$ & $<1050$ & $<881$ & $<918$ & $<<734$ & $<1050$ & NA & NA & $<2530$ & $<2670$ & $<2670$ & NA \\
\hline $\mathrm{Sr}$ & $<31.7$ & 532 & 531 & 541 & 531 & 535 & 534 & 1 & NA & 2130 & 2150 & 2140 & $>100$ \\
\hline $\mathrm{Ti}$ & $<3.64$ & 19.1 & 20.0 & 18.4 & 18.3 & 18.9 & 18.9 & 4 & $\mathrm{NA}$ & 7020 & 7070 & 7040 & +2 \\
\hline $\mathrm{Y}$ & $<198$ & $<181$ & $<227$ & $<190$ & $\begin{array}{r}2.50 \\
\mathrm{mg} / \mathrm{L} \\
\text { or } \\
98 \% \\
\end{array}$ & $\begin{array}{r}2.52 \\
\mathrm{mg} / \mathrm{L} \\
\text { or } \\
98 \%\end{array}$ & $\begin{array}{r}2.51 \\
\mathrm{mg} / \mathrm{L}\end{array}$ & 1 & $98 \%$ & $<546$ & $<577$ & $<577$ & NA \\
\hline $\mathrm{Zn}$ & $<19.8$ & 3090 & 3130 & 3090 & 3030 & 3030 & 3070 & 1 & NA & 220 & 211 & 215 & +34 \\
\hline $\mathrm{Zr}$ & $<10.5$ & 530 & 530 & 539 & 494 & 501 & 516 & 4 & NA & 904 & 928 & 916 & -5 \\
\hline \multicolumn{14}{|c|}{$\begin{array}{l}\text { Elemental analysis concentrations of slurry simulant reported on wet slurry basis; The AY-102/C-106 Melter Feed simulant contained } \\
36.92 \pm 0.05 \% \text { solids on oxide basis after heating at } 1100{ }^{\circ} \mathrm{C} \text {. Elemental analysis concentrations of the LCS glass reported on dry } \\
\text { powdered glass basis. }\end{array}$} \\
\hline
\end{tabular}


WSRC-TR-2005-00169, REVISION 0

SRNL-RPP-2005-00023, REVISION 0

Table 3-11. Elemental Analysis of AY-102/C-106 Simulant -

WTP Sample Type: HLW-2A -

Digestion Method: KOH Fusion in $\mathrm{Zr}$ crucibles

\begin{tabular}{|c|c|c|c|c|c|c|c|c|c|c|c|c|c|c|}
\hline Element $^{a}$ & $(\mu \mathrm{g} / \mathrm{g})$ & $\begin{array}{c}\text { Trial } \\
1 \\
(\mu \mathrm{g} / \mathrm{g})\end{array}$ & $\begin{array}{c}\text { Trial } \\
2 \\
(\mu \mathrm{g} / \mathrm{g})\end{array}$ & $\begin{array}{c}\text { Trial } \\
3 \\
(\mu \mathrm{g} / \mathrm{g})\end{array}$ & $\begin{array}{l}\text { Avg. } \\
(\mu \mathrm{g} / \mathrm{g})\end{array}$ & $(\%)$ & $\begin{array}{c}\text { Spike }^{b} . \\
1 \\
(\mu g / g)\end{array}$ & $\begin{array}{c}\text { Spike }^{b} . \\
2 \\
(\mu \mathrm{g} / \mathrm{g})\end{array}$ & $\begin{array}{c}\text { Spike } \\
\text { Avg. } \\
(\mu g / g)\end{array}$ & $\begin{array}{c}\text { Spike }^{\mathrm{b} .} \\
\text { Recovery } \\
(\mu \mathrm{g} / \mathrm{g})\end{array}$ & $\begin{array}{c}\text { LCS } \\
\text { Tria1 } \\
1 \\
(\mu \mathrm{g} / \mathrm{g})\end{array}$ & $\begin{array}{c}\text { LCS } \\
\text { Trial } 2 \\
(\mu \mathrm{g} / \mathrm{g})\end{array}$ & $\begin{array}{l}\text { LCS } \\
\text { Avg. } \\
(\mu \mathrm{g} / \mathrm{g})\end{array}$ & Error \\
\hline $\mathrm{Ag}$ & $<18.0$ & 529 & 742 & 578 & 616 & 18 & $\begin{array}{r}0.27 \\
\mathrm{mg} / \mathrm{L}\end{array}$ & $\begin{array}{c}0.19 \\
\mathrm{mg} / \mathrm{L}\end{array}$ & $\begin{array}{c}0.23 \\
\mathrm{mg} / \mathrm{L}\end{array}$ & $29 \%$ & 214 & 204 & 209 & NA \\
\hline $\mathrm{Al}$ & $<164$ & 16700 & 16800 & 17000 & 16800 & 1 & 16700 & 16700 & 16700 & NA & 22400 & 22500 & 22450 & -10 \\
\hline B & $<65.0$ & $<59.7$ & $<69.2$ & $<60.6$ & $<69.2$ & NA & $<59.7$ & $<59.7$ & $<59.7$ & NA & 23800 & 23700 & 23750 & -13 \\
\hline $\mathrm{Ba}$ & $<14.4$ & 375 & 341 & 338 & 351 & 6 & 445 & 449 & 447 & NA & 808 & 921 & 864 & +9 \\
\hline $\mathrm{Ca}$ & $<57.8$ & 2180 & 2220 & 2240 & 2213 & 1 & 2260 & 2220 & 2240 & NA & 10100 & 10100 & 10100 & -1 \\
\hline $\mathrm{Cd}$ & $<37.9$ & 54.8 & 65.3 & 53.3 & 57.8 & 11 & 0.82 & 0.79 & 0.81 & $101 \%$ & $<<124$ & $<120$ & $<124$ & NA \\
\hline $\mathrm{Ce}$ & $<220$ & 668 & 674 & 632 & 658 & 3 & 775 & 807 & 791 & NA & $<723$ & $<695$ & $<723$ & NA \\
\hline $\mathrm{Cr}$ & $<66.8$ & 802 & 840 & 829 & 824 & 2 & 804 & 852 & 828 & NA & 657 & 703 & 680 & +6 \\
\hline $\mathrm{Cu}$ & $<21.7$ & 140 & 135 & 140 & 138 & 2 & 143 & 144 & 144 & NA & $<71.1$ & $<68.4$ & $<71.1$ & NA \\
\hline $\mathrm{Fe}$ & $<92.0$ & 61700 & 62700 & 63100 & 62500 & 1 & 61900 & 62200 & 62050 & NA & 97100 & 97200 & 97150 & -1 \\
\hline $\mathrm{K}$ & $\mathrm{K}$ not $\mathrm{r}$ & orted-K & alt used & fusion & igestion & & & & & & & & & \\
\hline $\mathrm{La}$ & $<74.0$ & 244 & 205 & 174 & 208 & 17 & 352 & 353 & 353 & NA & $<243$ & $<234$ & $<243$ & NA \\
\hline $\mathrm{Li}$ & $<37.9$ & $<34.8$ & $<40.4$ & $<35.4$ & $<40.4$ & NA & $<34.8$ & $<34.8$ & $<34.8$ & NA & 13500 & 13700 & 13600 & -9 \\
\hline $\mathrm{Mg}$ & $<12.6$ & 607 & 615 & 622 & 615 & 1 & 625 & 619 & 622 & NA & 4960 & 4970 & 4960 & -5 \\
\hline $\mathrm{Mn}$ & $<5.41$ & 13600 & 13800 & 13900 & 13800 & 1 & 13600 & 13700 & 13600 & NA & 14300 & 14300 & 14300 & -2 \\
\hline Mo & $<271$ & $<249$ & $<288$ & $<253$ & $<288$ & NA & $<249$ & $<249$ & $<249$ & NA & $<888$ & $<855$ & $<888$ & NA \\
\hline $\mathrm{Na}$ & 465 & 15400 & 15700 & 15900 & 15670 & 2 & 15800 & 15700 & 15750 & NA & 79500 & 80000 & 79750 & -6 \\
\hline $\mathrm{Ni}$ & $<132$ & 1960 & 1970 & 1970 & 1970 & 1 & 1950 & 1970 & 1960 & NA & 8170 & 8060 & 8120 & -2 \\
\hline $\mathrm{P}$ & $<1360$ & $<1250$ & $<1440$ & $<1260$ & $<1440$ & NA & $<1250$ & $<1250$ & $<1250$ & NA & $<4450$ & $<4280$ & $<4450$ & NA \\
\hline $\mathrm{Pb}$ & $<955$ & 2850 & 2710 & 2850 & 2800 & 1 & 2770 & 2770 & 2770 & NA & $<3130$ & $<3010$ & $<3130$ & NA \\
\hline $\mathrm{S}$ & $<401$ & $<368$ & $<427$ & $<374$ & $<427$ & NA & $\begin{array}{c}0.92 \\
\mathrm{mg} / \mathrm{L}\end{array}$ & $\begin{array}{c}0.86 \\
\mathrm{mg} / \mathrm{L}\end{array}$ & $\begin{array}{c}0.89 \\
\mathrm{mg} / \mathrm{L}\end{array}$ & $111 \%$ & $<1310$ & $<1260$ & $<1310$ & NA \\
\hline $\mathrm{Sb}$ & $<103$ & 248 & 257 & 244 & 250 & 3 & $\begin{array}{r}0.77 \\
\mathrm{mg} / \mathrm{L} \\
\end{array}$ & $\begin{array}{c}0.78 \\
\mathrm{mg} / \mathrm{L} \\
\end{array}$ & $\begin{array}{c}0.78 \\
\mathrm{mg} / \mathrm{L} \\
\end{array}$ & $98 \%$ & 477 & 540 & 508 & NA \\
\hline $\mathrm{Si}$ & $<93.8$ & 17400 & 17800 & 17900 & 17600 & 2 & 17500 & 17600 & 17600 & NA & 219000 & 221000 & 220000 & -2 \\
\hline $\mathrm{Sn}$ & $<836$ & $<<68$ & $<890$ & $<>780$ & $<890$ & NA & $<768$ & $<<68$ & $<<68$ & NA & $<2740$ & $<2640$ & $<2740$ & NA \\
\hline $\mathrm{Sr}$ & $<28.9$ & 804 & 799 & 800 & 801 & 1 & 856 & 850 & 853 & NA & 2300 & 2260 & 2280 & $>+100$ \\
\hline $\mathrm{Th}$ & $<32.5$ & $<29.8$ & $<34.6$ & $<30.3$ & $<34.6$ & NA & $\begin{array}{c}0.73 \\
\mathrm{mg} / \mathrm{L}\end{array}$ & $\begin{array}{r}0.75 \\
\mathrm{mg} / \mathrm{L}\end{array}$ & $\begin{array}{c}0.74 \\
\mathrm{mg} / \mathrm{L}\end{array}$ & $93 \%$ & $<107$ & $<103$ & $<107$ & NA \\
\hline $\mathrm{Ti}$ & $<12.6$ & $<11.6$ & $<13.5$ & $<11.8$ & $<13.5$ & NA & $<11.6$ & $<11.6$ & $<11.6$ & NA & 6840 & 6830 & 6840 & -1 \\
\hline $\mathrm{Tl}$ & $<186$ & $<171$ & $<198$ & $<173$ & $<198$ & NA & $\begin{array}{c}0.82 \\
\mathrm{mg} / \mathrm{L} \\
\end{array}$ & $\begin{array}{c}0.82 \\
\mathrm{mg} / \mathrm{L}\end{array}$ & $\begin{array}{r}0.82 \\
\mathrm{mg} / \mathrm{L}\end{array}$ & $103 \%$ & $<610$ & $<587$ & $<610$ & NA \\
\hline $\mathrm{U}$ & $<90.2$ & $<82.9$ & 124 & $<84$ & $<124$ & NA & $\begin{array}{c}3.61 \\
\mathrm{mg} / \mathrm{L}\end{array}$ & $\begin{array}{c}3.60 \\
\mathrm{mg} / \mathrm{L}\end{array}$ & $\begin{array}{c}3.60 \\
\mathrm{mg} / \mathrm{L}\end{array}$ & $90 \%$ & $<296$ & $<285$ & $<296$ & NA \\
\hline $\mathrm{Zn}$ & $<18$ & 139 & 144 & 144 & 142 & 3 & 148 & 144 & 146 & NA & 194 & 221 & 208 & NA \\
\hline $\mathrm{Zr}$ & \multicolumn{14}{|c|}{ Not reported-Zr crucibles were used for these fusion digestions } \\
\hline $\begin{array}{l}\text { a. } \\
\text { b. }\end{array}$ & \multicolumn{14}{|c|}{$\begin{array}{l}\text { Elemental analysis concentrations of slurry simulant reported on wet slurry basis; The AY-102/C-106 simulant contained } 23.59 \pm 0.03 \% \text { solids } \\
\text { on oxide basis after heating at } 1100^{\circ} \mathrm{C} \text {. The elemental analysis concentration of the LCS glass reported on dry powdered glass basis. } \\
\text { Concentrations of spiked elements reported in } \mathrm{mg} / \mathrm{L} \text { to facilitate comparison with the theoretical concentrations. Ag, Cd, } \mathrm{S}, \mathrm{Sb} \text {, Th, and } \mathrm{Tl} \mathrm{were} \\
\text { spiked at } 0.8 \mathrm{mg} / \mathrm{L} \text { of the solutions after digestion; } \mathrm{U} \text { was spiked at } 4.0 \mathrm{mg} / \mathrm{L} \text { of the solutions after digestion. }\end{array}$} \\
\hline
\end{tabular}


WSRC-TR-2005-00169, REVISION 0

SRNL-RPP-2005-00023, REVISION 0

Table 3-12. Elemental Analysis of AZ-101 Simulant Type of WTP Waste: HLW-2A -

Digestion Method: KOH Fusion in Zirconium Crucibles

\begin{tabular}{|c|c|c|c|c|c|c|c|c|c|c|c|}
\hline Element $^{a}$ & $(\mu \mathrm{g} / \mathrm{g})$ & $(\mu \mathrm{g} / \mathrm{g})$ & $\begin{array}{c}\text { Trial } \\
2\end{array}$ & $\begin{array}{c}\text { Trial } \\
\mathbf{3}\end{array}$ & $(\mu \mathrm{g} / \mathrm{g})$ & RSD & $\begin{array}{c}\text { Avg. } \\
\text { Spike }^{\text {b }} \\
\text { Rec. } \\
\text { (From } \\
\text { Trials } \\
\text { 1- 3) } \\
(\%) \\
\end{array}$ & $\begin{array}{c}\text { LCS } \\
\text { Tria1 } \\
1\end{array}$ & $\begin{array}{c}\text { LCS } \\
\text { Trial } \\
2\end{array}$ & $\begin{array}{l}\text { LCS } \\
\text { Avg. }\end{array}$ & Error \\
\hline $\mathrm{Ag}$ & $<14.5$ & 48.9 & 48.2 & 45.5 & 47.5 & 4 & NA & 282 & 173 & 228 & NA \\
\hline $\mathrm{Al}$ & $<132$ & 23000 & 23300 & 24400 & 23600 & 3 & NA & 23900 & 23800 & 23800 & -5 \\
\hline B & $<52.1$ & $<47.7$ & $<47.5$ & $<41.4$ & $<47.5$ & NA & NA & 24200 & 24000 & 24100 & -12 \\
\hline $\mathrm{Ba}$ & $<11.6$ & 343 & 282 & 316 & 314 & 10 & NA & 810 & 784 & 797 & +1 \\
\hline $\mathrm{Ca}$ & $<46.3$ & 1870 & 1820 & 1800 & 1830 & 2 & NA & 10400 & 10500 & 10400 & +2 \\
\hline $\mathrm{Cd}$ & $<30.4$ & 3000 & 2910 & 2960 & 2960 & 2 & NA & $<138$ & $<135$ & $<138$ & NA \\
\hline $\mathrm{Ce}$ & 178 & 687 & 662 & 691 & 680 & 2 & NA & 1410 & 1120 & 1260 & NA \\
\hline $\mathrm{Cr}$ & $<27.9$ & 596 & 586 & 604 & 595 & 2 & NA & 519 & 375 & 447 & -30 \\
\hline $\mathrm{Cu}$ & $<17.4$ & 142 & 138 & 139 & 140 & 2 & NA & $<78.6$ & $<77.3$ & $<78.6$ & $\mathrm{NA}$ \\
\hline $\mathrm{Fe}$ & $<6.00$ & 56600 & 55600 & 55700 & 56000 & 1 & NA & 102000 & 101000 & 102000 & +4 \\
\hline $\mathrm{K}$ & Not $\mathrm{Me}$ & sured-K us & $\mathrm{d}$ in fusion & eagents & & & & & & & \\
\hline $\mathrm{La}$ & 64.4 & 972 & 828 & 858 & 886 & 9 & NA & 390 & 337 & 363 & NA \\
\hline $\mathrm{Li}$ & 52.4 & 51.6 & 52.5 & 55.0 & $\begin{array}{r}\text { NA- } \\
\text { blank } \\
\text { values }\end{array}$ & NA & NA & 15700 & 15500 & 15600 & +5 \\
\hline $\mathrm{Mg}$ & $<10.1$ & 393 & 380 & 389 & 387 & 2 & NA & 5170 & 5110 & 5140 & -1 \\
\hline $\mathrm{Mn}$ & $<4.34$ & 1500 & 1470 & 1480 & 1480 & 1 & NA & 14700 & 14500 & 14600 & 0 \\
\hline Mo & $<129$ & 241 & 212 & 205 & 219 & 9 & NA & 587 & 601 & 594 & NA \\
\hline $\mathrm{Na}$ & 748 & 10900 & 10500 & 10600 & 10700 & 2 & NA & 86600 & 82600 & 84600 & -1 \\
\hline $\mathrm{Ni}$ & $<42.0$ & 2710 & 2500 & 2470 & 2560 & 5 & NA & 8680 & 8000 & 8340 & +1 \\
\hline $\mathrm{P}$ & $<1090$ & $<996$ & $<992$ & $<864$ & $<996$ & NA & NA & $<4920$ & $<4840$ & $<4920$ & 0 \\
\hline $\mathrm{Pb}$ & $<766$ & $<701$ & $<699$ & $<609$ & $<701$ & NA & NA & $<3460$ & $<3410$ & $<3460$ & NA \\
\hline $\mathrm{Sb}$ & $<82.5$ & 314 & 298 & 309 & 307 & 3 & NA & 781 & 643 & 712 & NA \\
\hline $\mathrm{Si}$ & $<75.3$ & 3650 & 3550 & 3630 & 3620 & 2 & NA & 231000 & 227000 & 22900 & +2 \\
\hline $\mathrm{Sn}$ & $<670$ & 1000 & 1010 & 994 & 1000 & 1 & NA & $<3030$ & $<2980$ & $<3030$ & NA \\
\hline $\mathrm{Sr}$ & $<23.2$ & 907 & 807 & 838 & 851 & 6 & NA & 2130 & 2140 & 2140 & $>100$ \\
\hline $\mathrm{Ti}$ & $<2.66$ & 82.7 & 77.8 & 79.9 & 80.1 & 3 & NA & 6930 & 6880 & 6900 & 0 \\
\hline $\mathrm{Y}$ & $<145$ & $\begin{array}{r}1.25 \\
\mathrm{mg} / \mathrm{L} \text { or } \\
31 \% \\
\text { recovery }\end{array}$ & $\begin{array}{r}1.39 \\
\mathrm{mg} / \mathrm{L} \text { or } \\
35 \% \\
\text { recovery }\end{array}$ & $\begin{array}{r}1.18 \\
\mathrm{mg} / \mathrm{L} \text { or } \\
30 \% \\
\text { recovery }\end{array}$ & $\begin{array}{r}1.27 \\
\mathrm{mg} / \mathrm{L} \text { or } \\
32 \% \\
\text { recovery }\end{array}$ & 8 & $32 \%$ & $<655$ & $<644$ & $<655$ & NA \\
\hline $\mathrm{Zn}$ & $<14.5$ & 81.4 & 76.3 & 80.8 & 79.5 & 3.5 & NA & 111 & 104 & 108 & -33 \\
\hline $\mathrm{Zr}$ & \multicolumn{11}{|c|}{ Not Measured-Zr crucibles used } \\
\hline b. & \multicolumn{11}{|c|}{$\begin{array}{l}\text { Elemental analysis concentrations of slurry simulant reported on wet slurry basis; The AZ-101 simulant contained } \\
20.23 \pm 0.05 \% \text { solids on oxide basis after heating at } 1100^{\circ} \mathrm{C} \text {. Elemental analysis concentrations of the LCS glass } \\
\text { reported on dry powdered glass basis. } \\
\text { Concentration of spiked Y reported in } \mathrm{mg} / \mathrm{L} \text { to facilitate comparison with the theoretical concentration. Y was spiked } \\
\text { into sample before the digestion so that the theoretical concentration was } 4.0 \mathrm{mg} / \mathrm{L} \text {. }\end{array}$} \\
\hline
\end{tabular}


WSRC-TR-2005-00169, REVISION 0

SRNL-RPP-2005-00023, REVISION 0

Table 3-13. Elemental Analysis of AY-102/C-106 Melter Feed Vitrified into Glass WTP Sample Type: HLW-2B -

Sample Digestion Method: Potassium Carbonate Fusion in Pt Crucibles

\begin{tabular}{|c|c|c|c|c|c|c|c|c|c|c|c|}
\hline Element $^{\mathrm{a}}$ & $(\mu \mathrm{g} / \mathrm{g})$ & $\begin{array}{c}\text { Trial } \\
1 \\
\\
(\mu \mathrm{g} / \mathrm{g})\end{array}$ & $\begin{array}{c}\text { Trial } \\
2 \\
\\
(\mu \mathrm{g} / \mathrm{g})\end{array}$ & $\begin{array}{c}\text { Trial } \\
\mathbf{3}\end{array}$ & $\begin{array}{c}\text { Avg. } \\
\text { of } \\
\text { Trials } \\
1-3 \\
\\
(\mu \mathrm{g} / \mathrm{g})\end{array}$ & (\%) & $\begin{array}{c}\text { Avg. } \\
\text { Spike. } \\
\text { Recovery } \\
\text { (From } \\
\text { Trials } \\
1-3) \\
(\%)\end{array}$ & $\begin{array}{c}\text { LCS } \\
\text { Tria1 } \\
1\end{array}$ & $\begin{array}{c}\text { LCS } \\
\text { Trial } \\
2\end{array}$ & $\begin{array}{l}\text { LCS } \\
\text { Avg. }\end{array}$ & Error \\
\hline $\mathrm{Ag}$ & $<26.8$ & 443 & 397 & 472 & 437 & 9 & NA & $<56$ & $<54$ & $<56$ & NA \\
\hline $\mathrm{Al}$ & $<244$ & 11100 & 11000 & 11000 & 11000 & 1 & NA & 25200 & 24500 & 24900 & 0 \\
\hline B & $<96.5$ & 10800 & 10800 & 10800 & 10800 & 0 & NA & 25800 & 25300 & 25600 & -5 \\
\hline $\mathrm{Ba}$ & $<21.5$ & 332 & 332 & 337 & 334 & 1 & NA & 901 & 891 & 896 & +13 \\
\hline $\mathrm{Ca}$ & $<85.8$ & 1320 & 1280 & 1310 & 1300 & 2 & NA & 10600 & 10200 & 10400 & +2 \\
\hline $\mathrm{Cd}$ & $<56.3$ & $<42.3$ & $<63.0$ & $<48.2$ & $<63.0$ & NA & NA & $<118$ & $<115$ & $<118$ & $\mathrm{NA}$ \\
\hline $\mathrm{Ce}$ & $<327$ & 666 & 783 & 755 & 735 & 8 & NA & $<684$ & $<667$ & $<684$ & NA \\
\hline $\mathrm{Cr}$ & $<51.6$ & 411 & 406 & 380 & 399 & 4 & NA & 641 & 417 & 529 & -17 \\
\hline $\mathrm{Cu}$ & $<32.2$ & 86.4 & 91.0 & 93.4 & 90.3 & 4 & NA & $<67$ & $<65$ & $<66$ & NA \\
\hline $\mathrm{Fe}$ & $<11.1$ & 36300 & 35300 & 36000 & 35900 & 1 & NA & 101100 & 96900 & 99000 & +2 \\
\hline $\mathrm{K}$ & \multicolumn{11}{|c|}{ Not Measured-K used in fusion reagent } \\
\hline $\mathrm{La}$ & $<110$ & 382 & 395 & 399 & 392 & 2 & NA & $<230$ & $<224$ & $<230$ & NA \\
\hline $\mathrm{Li}$ & 78.0 & 4560 & 4400 & 4550 & 4500 & 2 & NA & 15900 & 15400 & 15600 & +5 \\
\hline $\mathrm{Mg}$ & $<18.8$ & 402 & 382 & 396 & 393 & 3 & NA & 5200 & 5040 & 5120 & -2 \\
\hline $\mathrm{Mn}$ & $<8.04$ & 7900 & 7830 & 7860 & 7860 & 1 & NA & 15100 & 14700 & 14900 & +2 \\
\hline Mo & $<239$ & $<180$ & $<267$ & $<205$ & $<267$ & NA & NA & $<500$ & $<488$ & $<500$ & NA \\
\hline $\mathrm{Na}$ & $<582$ & 29000 & 29100 & 29000 & 29000 & 1 & NA & 82400 & 79200 & 80800 & -5 \\
\hline $\mathrm{Ni}$ & $<77.8$ & 1090 & 565 & 929 & 861 & 31 & NA & 5750 & 4830 & 5290 & -36 \\
\hline $\mathrm{P}$ & $<2010$ & $<1510$ & $<2250$ & $<1720$ & $<2250$ & NA & NA & $<4200$ & $<4110$ & $<4200$ & $\mathrm{NA}$ \\
\hline $\mathrm{Pb}$ & $<1420$ & 1520 & $<1590$ & 1610 & $<1610$ & $\mathrm{NA}$ & NA & $<2970$ & $<2890$ & $<2970$ & $\mathrm{NA}$ \\
\hline $\mathrm{Sb}$ & $<153$ & 242 & 260 & 297 & 266 & 11 & NA & $<320$ & 1070 & $<1070$ & NA \\
\hline $\mathrm{Si}$ & $<139$ & 82000 & 81300 & 82400 & 81900 & 1 & NA & 230000 & 228000 & 229000 & +2 \\
\hline $\mathrm{Sn}$ & $<1240$ & $<933$ & $<1390$ & $<1060$ & $<1390$ & NA & NA & $<2600$ & $<2530$ & $<2600$ & NA \\
\hline $\mathrm{Sr}$ & $<<42.9$ & 543 & 514 & 533 & 530 & 3 & NA & 2140 & 2060 & 2100 & $>100$ \\
\hline $\mathrm{Ti}$ & $<4.93$ & 18.9 & 20.1 & 18.8 & 19.3 & 4 & NA & 7340 & 7080 & 7210 & +4 \\
\hline $\mathrm{Y}$ & $<268$ & $\begin{array}{r}1.93 \\
\mathrm{mg} / \mathrm{L} \text { or } \\
96 \% \\
\text { recovery }\end{array}$ & $\begin{array}{r}1.92 \\
\mathrm{mg} / \mathrm{L} \text { or } \\
95 \% \\
\text { recovery }\end{array}$ & $\begin{array}{r}1.93 \\
\mathrm{mg} / \mathrm{L} \text { or } \\
95 \% \\
\text { recovery }\end{array}$ & 1.93 & 1 & $95 \%$ & $<561$ & $<547$ & $<561$ & NA \\
\hline $\mathrm{Zn}$ & $<26.8$ & 2960 & 2930 & 2970 & 2950 & 1 & NA & $<56.1$ & $<54.7$ & $<56.1$ & NA \\
\hline $\mathrm{Zr}$ & $<14.2$ & 494 & 483 & 504 & 494 & 2 & NA & 798 & 807 & 802 & -16 \\
\hline b. & $\begin{array}{l}\text { Elementa } \\
\text { simulant } \\
\text { of the LC } \\
\text { Concentr } \\
\text { into samp }\end{array}$ & $\begin{array}{l}\text { analysis co } \\
\text { gntained } 3 \\
\text { glass repo } \\
\text { ion of spik } \\
\text { e before th }\end{array}$ & $\begin{array}{l}\text { centration } \\
92 \pm 0.05 \\
\text { ted on dry } \\
\text { d Y report } \\
\text { digestion }\end{array}$ & $\begin{array}{l}\text { of slurry si } \\
\text { solids on } \\
\text { owdered gl } \\
\text { in } \mathrm{mg} / \mathrm{L} \mathrm{t} \\
\text { that the th }\end{array}$ & $\begin{array}{l}\text { 1ulant re } \\
\text { xide basi } \\
\text { ss basis. } \\
\text { facilitat } \\
\text { oretical }\end{array}$ & compa & $\begin{array}{l}\text { on with the } \\
\text { ion was } 2.0\end{array}$ & $\begin{array}{l}\text { is; The A } \\
\text { C. Eleme } \\
\text { heoretical } \\
\text { g/L. }\end{array}$ & $\begin{array}{l}-102 / \mathrm{C}-1 \\
\text { tal analys }\end{array}$ & $\begin{array}{l}6 \text { Melter } \\
\text { concent }\end{array}$ & $\begin{array}{l}\text { eed } \\
\text { ions } \\
\text { piked }\end{array}$ \\
\hline
\end{tabular}


WSRC-TR-2005-00169, REVISION 0

SRNL-RPP-2005-00023, REVISION 0

Table 3-14. Elemental Analysis of AY-102/C-106 Simulant Type of WTP Waste: HLW-2A -

Digestion Method: Warm Acidification with $\mathrm{HNO}_{3} / \mathrm{H}_{2} \mathrm{O}_{2} / \mathrm{HCl}$

\begin{tabular}{|c|c|c|c|c|c|c|c|c|c|c|c|}
\hline Element $^{a}$ & $(\mu \mathrm{g} / \mathrm{g})$ & $\begin{array}{c}\text { Trial } \\
1\end{array}$ & $\begin{array}{c}\text { Trial } \\
2\end{array}$ & $\begin{array}{c}\text { Trial } \\
\mathbf{3}\end{array}$ & $(\mu \mathrm{g} / \mathrm{g})$ & RSD & $\begin{array}{c}\text { Spike }^{\text {b. }} \\
\text { Recovery } \\
\text { (From } \\
\text { Trial 3) } \\
(\%)\end{array}$ & $\begin{array}{c}\text { LCS }^{\mathbf{c}} \\
\text { Tria1 } \\
1 \\
(\mu \mathrm{g} / \mathrm{g}) \\
\end{array}$ & $\begin{array}{c}\text { LCS }^{\mathbf{c}} \\
\text { Trial } \\
2 \\
(\mu \mathrm{g} / \mathrm{g}) \\
\end{array}$ & $\begin{array}{l}\text { LCS }^{\mathbf{c}} \\
\text { Avg. }\end{array}$ & Error $^{\mathrm{c}}$ \\
\hline $\mathrm{Ag}$ & $<34.4$ & 438 & 451 & 798 & 562 & 36 & NA & $<66.9$ & $<65.2$ & $<66.9$ & NA \\
\hline $\mathrm{Al}$ & $<313$ & 13000 & 12500 & 15400 & 13600 & 11 & $\mathrm{NA}$ & 24600 & 24800 & 24700 & -1 \\
\hline $\mathrm{Ca}$ & $<110$ & 2460 & 2390 & 2590 & 2480 & 4 & NA & 12800 & 12700 & 12800 & +25 \\
\hline $\mathrm{Cd}$ & $<72.2$ & $<63.8$ & $<82.5$ & $<72.1$ & $<82.5$ & NA & NA & $<140$ & $<137$ & $<140$ & NA \\
\hline $\mathrm{Ce}$ & $<419$ & 1030 & 1100 & 1340 & 1160 & 14 & NA & 1310 & 1180 & 1240 & NA \\
\hline $\mathrm{Cr}$ & $<66.2$ & 762 & 745 & 855 & 787 & 8 & NA & 1400 & 1000 & 1200 & 47 \\
\hline $\mathrm{Cu}$ & $<41.3$ & 140 & 127 & 151 & 139 & 9 & NA & $<80.3$ & $<78.3$ & $<80.3$ & NA \\
\hline $\mathrm{Mg}$ & $<24.1$ & 644 & 608 & 684 & 645 & 6 & NA & 5280 & 5310 & 5300 & +2 \\
\hline $\mathrm{Mn}$ & $<10.3$ & 15000 & 14800 & 16000 & 15300 & 4 & NA & 15000 & 15100 & 15000 & +3 \\
\hline Mo & $<306$ & $<271$ & $<350$ & $<306$ & $<350$ & NA & NA & 2080 & 1490 & 1780 & NA \\
\hline $\mathrm{Na}$ & $<746$ & 18100 & 17500 & 18000 & 17900 & 2 & NA & NA & NA & NA & NA \\
\hline $\mathrm{Ni}$ & $<<99.7$ & 2270 & 2110 & 2290 & 2220 & 4 & NA & $\mathrm{Ni}$ & NA & NA & NA \\
\hline $\mathrm{P}$ & $<2580$ & $<2280$ & $<2950$ & $<2580$ & $<2980$ & & NA & $<5020$ & $<4900$ & NA & NA \\
\hline $\mathrm{Pb}$ & $<1820$ & 3000 & 3140 & 3400 & 3180 & 6 & NA & $<3540$ & $<3450$ & NA & NA \\
\hline $\mathrm{Sb}$ & $<196$ & 215 & 263 & 403 & 293 & 33 & NA & 4530 & 3210 & 3870 & NA \\
\hline $\mathrm{Si}$ & $<179$ & 7180 & 6750 & 8480 & 7470 & 12 & $\mathrm{NA}$ & 237000 & 239000 & 238000 & +6 \\
\hline $\mathrm{Sn}$ & $<1590$ & $<1410$ & $<1820$ & $<1590$ & $<<1820$ & NA & NA & $<3100$ & $<3020$ & $<3100$ & NA \\
\hline $\mathrm{Zn}$ & $<34.4$ & 97.2 & 80.5 & 126 & 101 & 23 & NA & 3220 & 2120 & 2670 & +29 \\
\hline $\mathrm{Zr}$ & $\begin{array}{l}<18.3 \\
\end{array}$ & 223 & 235 & 473 & 310 & 45 & NA & 1020 & 1190 & 1100 & +15 \\
\hline b. & \multicolumn{11}{|c|}{$\begin{array}{l}\text { Elemental analysis concentrations of slurry simulant reported on wet slurry basis; The AY-102/C-106 simulant } \\
\text { contained } 23.59 \pm 0.03 \% \text { solids on oxide basis after heating at } 1100{ }^{\circ} \mathrm{C} \text {. Elemental analysis concentrations of the } \\
\text { LCS glass reported on dry powdered glass basis. } \\
\text { Concentration of spiked Y reported in } \mathrm{mg} / \mathrm{L} \text { to facilitate comparison with the theoretical concentration. Y was } \\
\text { spiked into sample before the digestion so that the theoretical concentration was } 2.0 \mathrm{mg} / \mathrm{L} \text {. } \\
\text { The warm mixed-acid method is ineffective on glass matrices. Solutions from sodium peroxide fusions were } \\
\text { analyzed. }\end{array}$} \\
\hline
\end{tabular}


WSRC-TR-2005-00169, REVISION 0
SRNL-RPP-2005-00023, REVISION 0

Table 3-15. Elemental Analysis of AZ-101 Simulant Digestion Method: Warm Acidification with $\mathrm{HNO}_{3} / \mathrm{H}_{2} \mathrm{O}_{2} / \mathrm{HCl}$

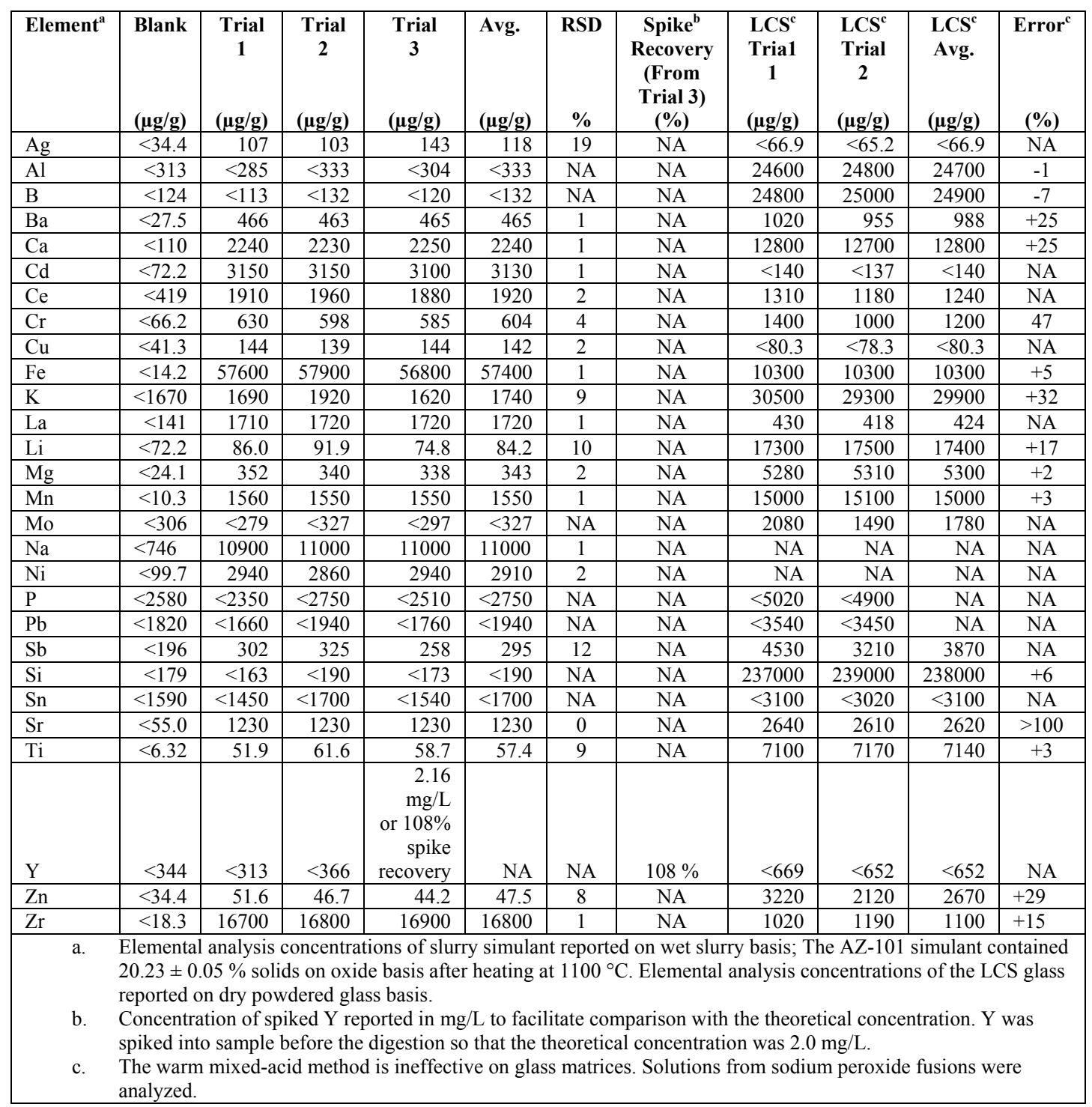


WSRC-TR-2005-00169, REVISION 0

SRNL-RPP-2005-00023, REVISION 0

Table 3-16. Elemental Analysis of AY-102/C-106 Melter Feed WTP Sample Type: HLW-2B -

Digestion Method: Warm Acidification with $\mathrm{HNO}_{3} / \mathrm{H}_{2} \mathrm{O}_{2} / \mathrm{HCl}$

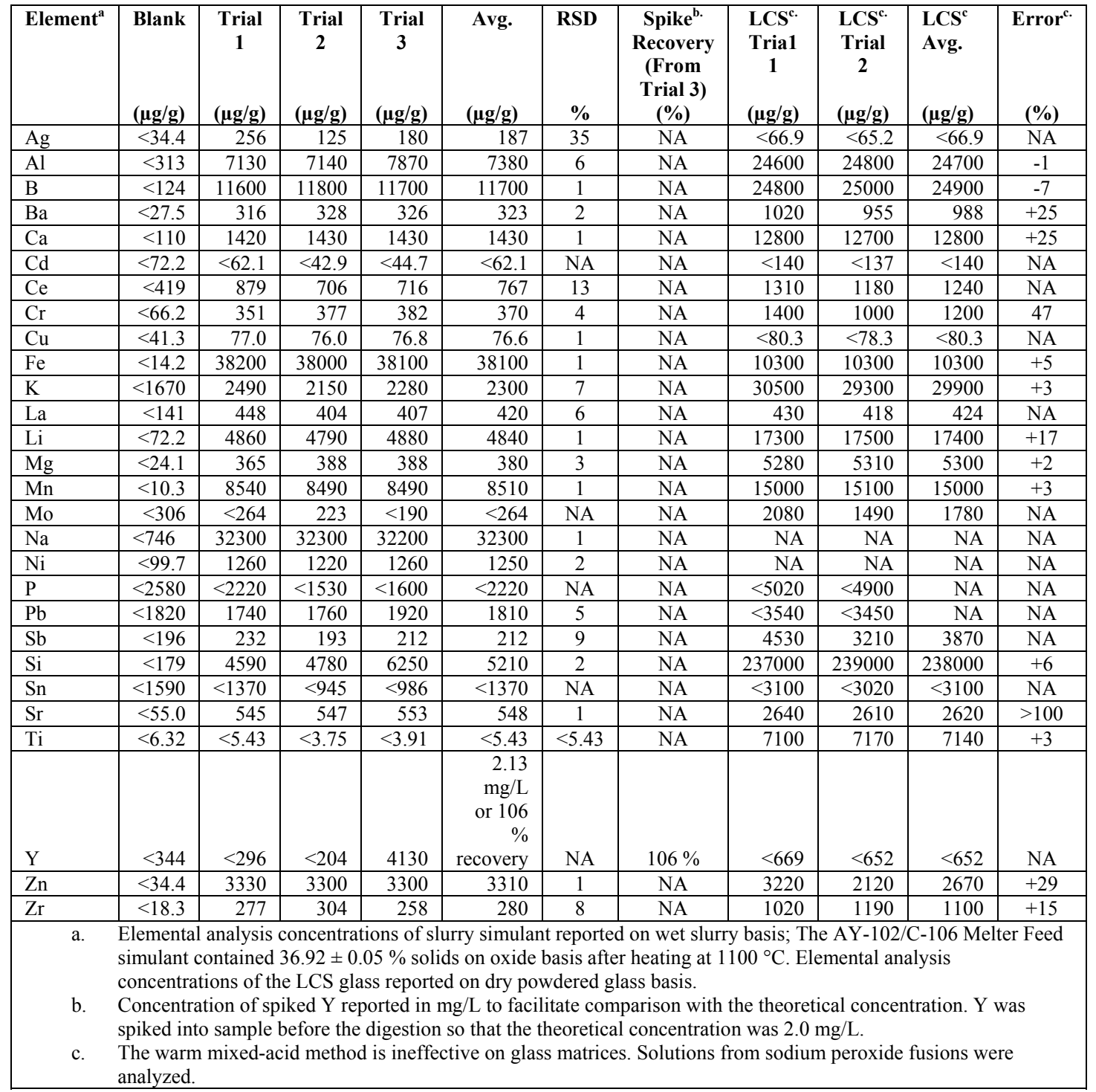


WSRC-TR-2005-00169, REVISION 0
SRNL-RPP-2005-00023, REVISION 0

Table 3-17. Elemental Analysis of AY-102/C-106 Simulant WTP Sample Type:HLW-2A Digestion Method: HF-HCl with Heating

\begin{tabular}{|c|c|c|c|c|c|c|c|c|c|c|c|c|c|c|}
\hline Element $^{a}$ & $(\mu \mathrm{g} / \mathrm{g})$ & $\begin{array}{c}\text { Trial } \\
1 \\
(\mu \mathrm{g} / \mathrm{g})\end{array}$ & $\begin{array}{c}\text { Trial } \\
2 \\
(\mu \mathrm{g} / \mathrm{g})\end{array}$ & $\begin{array}{c}\text { Trial } \\
3 \\
(\mu \mathrm{g} / \mathrm{g})\end{array}$ & $(\mu \mathrm{g} / \mathrm{g})$ & RSD & $\begin{array}{c}\text { Spike }^{b} . \\
1 \\
(\mu \mathrm{g} / \mathrm{g})\end{array}$ & $\begin{array}{c}\text { Spike }^{b} . \\
2 \\
(\mu \mathrm{g} / \mathrm{g})\end{array}$ & $\begin{array}{l}\text { Spike } \\
\text { Avg. } \\
(\mu g / g)\end{array}$ & $\begin{array}{c}\text { Spike }{ }^{b .} \\
\text { recov. } \\
(\%)\end{array}$ & $\begin{array}{c}\text { LCS } \\
\text { Tria1 } \\
1 \\
(\mu \mathrm{g} / \mathrm{g})\end{array}$ & $\begin{array}{c}\text { LCS } \\
\text { Trial } \\
2 \\
(\mu \mathrm{g} / \mathrm{g})\end{array}$ & $\begin{array}{l}\text { LCS } \\
\text { Avg. } \\
(\mu \mathrm{g} / \mathrm{g})\end{array}$ & Error \\
\hline $\mathrm{Ag}$ & $<17.2$ & 217 & 229 & 178 & 208 & 13 & $<1$ & $<1$ & $<1$ & $<1 \%$ & $<53.1$ & $<55.3$ & $<55.3$ & NA \\
\hline $\mathrm{Al}$ & 231 & 11800 & 11800 & 11700 & 11800 & 1 & 33200 & 33200 & 33200 & NA & 22400 & 21000 & 21700 & -13 \\
\hline B & 588 & 732 & 559 & 632 & 641 & 14 & 75100 & 75000 & 75050 & NA & 26200 & 26200 & 26200 & -3 \\
\hline $\mathrm{Ba}$ & $<13.8$ & 296 & 285 & 255 & 279 & 8 & 264 & 278 & 271 & NA & 770 & 691 & 730 & -7 \\
\hline $\mathrm{Ca}$ & $<55.0$ & 2010 & 1980 & 1920 & 1970 & 2 & 2300 & 2320 & 2310 & NA & 10800 & 8330 & 9560 & -6 \\
\hline $\mathrm{Cd}$ & $<36.1$ & 94.2 & 93.4 & 91.4 & 93.0 & 2 & $\begin{array}{r}0.72 \\
\mathrm{mg} / \mathrm{L}\end{array}$ & $\begin{array}{c}0.73 \\
\mathrm{mg} / \mathrm{L}\end{array}$ & $\begin{array}{r}0.72 \\
\mathrm{mg} / \mathrm{L}\end{array}$ & $90 \%$ & $<111$ & $<116$ & $<116$ & NA \\
\hline $\mathrm{Ce}$ & $<210$ & $<215$ & $<214$ & $<192$ & $<215$ & NA & $<215$ & $<215$ & $<215$ & NA & $<648$ & $<675$ & $<675$ & NA \\
\hline $\mathrm{Cr}$ & $<63.6$ & 837 & 833 & 792 & 821 & 3 & 829 & 847 & 838 & NA & 581 & 574 & 577 & -10 \\
\hline $\mathrm{Cu}$ & $<20.6$ & 152 & 152 & 151 & 152 & 1 & 152 & 150 & 151 & NA & $<63.7$ & $<66.3$ & $<66.7$ & NA \\
\hline $\mathrm{Fe}$ & $<87.7$ & 65200 & 65000 & 64700 & 65000 & 1 & 64000 & 63900 & 64000 & NA & 97900 & 96900 & 97400 & -1 \\
\hline $\mathrm{K}$ & $<834$ & $<856$ & $<851$ & $<763$ & $<856$ & NA & 1410 & 1270 & 1340 & NA & 21100 & 20200 & 20650 & -9 \\
\hline $\mathrm{La}$ & $<70.5$ & $<72.4$ & $<71.9$ & $<64.5$ & $<72.4$ & NA & $<72.4$ & $<72.4$ & $<72.4$ & NA & $<218$ & $<<227$ & $<<227$ & NA \\
\hline $\mathrm{Li}$ & $<36.1$ & $<37.1$ & $<36.8$ & $<33.0$ & $<37.1$ & NA & $<37.1$ & $<37.1$ & $<37.1$ & NA & 14700 & 14400 & 14400 & -4 \\
\hline $\mathrm{Mg}$ & $<12.0$ & 675 & 671 & 674 & 673 & 1 & 754 & 755 & 755 & NA & 5120 & 5100 & 5110 & -2 \\
\hline $\mathrm{Mn}$ & $<5.16$ & 14400 & 14400 & 14300 & 14370 & 1 & 14000 & 14000 & 14000 & NA & 14300 & 14200 & 14200 & -2 \\
\hline Mo & $<258$ & $<265$ & $<263$ & $<236$ & $<265$ & NA & $<265$ & $<265$ & $<265$ & NA & $<796$ & $<829$ & $<829$ & NA \\
\hline $\mathrm{Na}$ & 660 & 17300 & 17100 & 17000 & 17130 & 1 & 75300 & 75500 & 75400 & NA & 84000 & 81700 & 82850 & -3 \\
\hline $\mathrm{Ni}$ & $<125$ & 2110 & 2090 & 2100 & 2100 & 1 & 2110 & 2120 & 2115 & NA & 8320 & 8270 & 8300 & 0 \\
\hline $\mathrm{P}$ & $<1290$ & $<1330$ & 1350 & 1460 & $<1460$ & NA & $<1330$ & $<1330$ & $<1330$ & NA & $<3990$ & $<4150$ & $<4150$ & NA \\
\hline $\mathrm{Pb}$ & $<<909$ & 2970 & 2870 & 2920 & 2920 & 2 & 2970 & 2970 & 2970 & NA & $<2810$ & $<2920$ & $<2920$ & $\mathrm{NA}$ \\
\hline S & $<382$ & $<392$ & $<389$ & $<349$ & $<392$ & NA & 1270 & $\begin{array}{c}0.79 \\
\mathrm{mg} / \mathrm{L}\end{array}$ & $\begin{array}{r}0.79 \\
\mathrm{mg} / \mathrm{L}\end{array}$ & $99 \%$ & $<1180$ & $<1230$ & $<1230$ & NA \\
\hline $\mathrm{Sb}$ & $<98.0$ & 222 & 223 & 202 & 216 & 5 & $\begin{array}{c}0.81 \\
\mathrm{mg} / \mathrm{L}\end{array}$ & $\begin{array}{c}0.77 \\
\mathrm{mg} / \mathrm{L}\end{array}$ & $\begin{array}{c}0.79 \\
\mathrm{mg} / \mathrm{L}\end{array}$ & $99 \%$ & 322 & 343 & 333 & NA \\
\hline $\mathrm{Si}$ & \multicolumn{14}{|c|}{ Not measured- uncomplexed high HF matrix results in high Si background signal } \\
\hline $\mathrm{Sn}$ & $<796$ & $<817$ & $<812$ & $<728$ & $<817$ & NA & 3490 & 3510 & 3500 & NA & $<2460$ & $<2560$ & $<2560$ & NA \\
\hline $\mathrm{Sr}$ & $<27.5$ & 767 & 760 & 736 & 754 & 2 & 866 & 881 & 872 & NA & 2400 & 1870 & 2135 & $>+100$ \\
\hline $\mathrm{Th}$ & $<30.9$ & $<31.8$ & $<31.6$ & $<28.3$ & $<31.8$ & NA & 0.73 & 0.74 & 0.74 & $93 \%$ & $<95.6$ & $<99.5$ & $<99.5$ & NA \\
\hline $\mathrm{Ti}$ & $<12.0$ & $<12.4$ & $<12.3$ & 11.2 & $<11.2$ & NA & 92.9 & 92.8 & 92.9 & NA & 6860 & 6780 & 6820 & -1 \\
\hline $\mathrm{Tl}$ & $<177$ & $<182$ & $<181$ & $<162$ & $<182$ & NA & 0.74 & 0.72 & 0.73 & $91 \%$ & $<547$ & $<569$ & $<569$ & NA \\
\hline $\mathrm{U}$ & $<85.9$ & $<88.2$ & $<87.7$ & $<78.7$ & $<88.2$ & $\mathrm{NA}$ & 3.81 & 3.71 & 3.76 & $94 \%$ & $<265$ & $<276$ & $<276$ & NA \\
\hline $\mathrm{Zn}$ & $<17.2$ & 144 & 144 & 144 & 144 & 0 & 146 & 148 & 147 & NA & 257 & 187 & 222 & +39 \\
\hline $\mathrm{Zr}$ & 122 & 866 & 859 & 858 & 861 & 1 & 1500 & 1500 & 1500 & NA & 1030 & 1020 & 1020 & -7 \\
\hline b. & \multicolumn{14}{|c|}{$\begin{array}{l}\text { Elemental analysis concentrations of slurry simulant reported on wet slurry basis; The AY-102/C-106 simulant contained } 23.59 \pm 0.03 \% \\
\text { solids on oxide basis after heating at } 1100^{\circ} \mathrm{C} \text {. Elemental analysis concentrations of the LCS glass reported on dry powdered glass basis. } \\
\text { Concentrations of spiked elements reported in } \mathrm{mg} / \mathrm{L} \text { to facilitate comparison with the theoretical concentrations. Ag, Cd, } \mathrm{S}, \mathrm{Sb} \text {, Th, and } \\
\text { Tl were spiked at } 0.8 \mathrm{mg} / \mathrm{L} \text { of the solutions after digestion; U was spiked at } 4.0 \mathrm{mg} / \mathrm{L} \text { of the solutions after digestion. }\end{array}$} \\
\hline
\end{tabular}


WSRC-TR-2005-00169, REVISION 0
SRNL-RPP-2005-00023, REVISION 0

Table 3-18. Elemental Analysis of AY-102/C-106 Simulant Type of WTP Waste: HLW-2A -

Digestion Method: Aqua Regia

\begin{tabular}{|c|c|c|c|c|c|c|c|c|c|c|c|c|c|c|}
\hline Element $^{\mathrm{a}}$ & $(\mu \mathrm{g} / \mathrm{g})$ & $\begin{array}{c}\text { Trial } \\
1 \\
(\mu \mathrm{g} / \mathrm{g})\end{array}$ & $\begin{array}{c}\text { Trial } \\
2 \\
(\mu \mathrm{g} / \mathrm{g})\end{array}$ & $\begin{array}{c}\text { Trial } \\
3 \\
(\mu \mathrm{g} / \mathrm{g})\end{array}$ & $(\mu \mathrm{g} / \mathrm{g})$ & (\%) & $\begin{array}{c}\text { Spike }^{\mathrm{b} .} \\
1 \\
(\mu \mathrm{g} / \mathrm{g})\end{array}$ & $\begin{array}{c}\text { Spike }^{\mathrm{b} .} \\
2 \\
(\mu \mathrm{g} / \mathrm{g})\end{array}$ & $\begin{array}{l}\text { Spike }{ }^{\text {b. }} \\
\text { Avg. } \\
(\mu \mathrm{g} / \mathrm{g})\end{array}$ & $\begin{array}{c}\text { Spike }^{\text {b. }} \\
\text { Recov. } \\
(\%)\end{array}$ & $\begin{array}{c}\text { LCS } \\
\text { Tria1 } \\
1 \\
(\mu \mathrm{g} / \mathrm{g})\end{array}$ & $\begin{array}{c}\text { LCS } \\
\text { Trial } \\
2 \\
(\mu \mathrm{g} / \mathrm{g})\end{array}$ & $\begin{array}{l}\text { LCS } \\
\text { Avg. } \\
(\mu \mathrm{g} / \mathrm{g})\end{array}$ & Error \\
\hline $\mathrm{Ag}$ & $<17.2$ & 177 & 167 & 182 & 175 & 4 & $\begin{array}{c}0.64 \\
\mathrm{mg} / \mathrm{L}\end{array}$ & $\begin{array}{c}0.67 \\
\mathrm{mg} / \mathrm{L}\end{array}$ & $\begin{array}{c}0.66 \\
\mathrm{mg} / \mathrm{L}\end{array}$ & $83 \%$ & $<55.6$ & $<49.6$ & $<55.6$ & NA \\
\hline $\mathrm{Al}$ & $<156$ & 11800 & 11800 & 11700 & 11800 & 1 & 11800 & 11800 & 11800 & NA & 22400 & 21000 & 21700 & -13 \\
\hline $\mathrm{B}$ & $<61.9$ & $<68.4$ & $<56.0$ & $<63.8$ & $<68.4$ & NA & $<68.4$ & $<68.4$ & $<68.4$ & NA & 25600 & 24200 & 24900 & -7 \\
\hline $\mathrm{Ba}$ & $<13.8$ & 564 & 566 & 567 & 566 & 1 & 572 & 570 & 571 & NA & 774 & 730 & 752 & -5 \\
\hline $\mathrm{Ca}$ & $<55.0$ & 2330 & 2320 & 2300 & 2320 & 1 & 2310 & 2300 & 2300 & $\mathrm{NA}$ & 10200 & 9750 & 9980 & -2 \\
\hline $\mathrm{Cd}$ & $<36.1$ & 89.2 & 86.7 & 85.2 & 87.0 & 2 & $\begin{array}{c}0.79 \\
\mathrm{mg} / \mathrm{L}\end{array}$ & $\begin{array}{c}0.78 \\
\mathrm{mg} / \mathrm{L}\end{array}$ & $\begin{array}{c}0.78 \\
\mathrm{mg} / \mathrm{L}\end{array}$ & $98 \%$ & $<117$ & $<104$ & $<117$ & NA \\
\hline $\mathrm{Ce}$ & $<210$ & 934 & 913 & 925 & 924 & 1 & 992 & 954 & 973 & NA & $<678$ & $<605$ & $<678$ & NA \\
\hline $\mathrm{Cr}$ & $<63.6$ & 833 & 827 & 845 & 835 & 1 & 824 & 841 & 832 & NA & 568 & 658 & 613 & -4 \\
\hline $\mathrm{Cu}$ & $<20.6$ & 142 & 144 & 142 & 143 & 1 & 151 & 148 & 150 & NA & $<66.7$ & $<59.6$ & $<66.7$ & $\mathrm{NA}$ \\
\hline $\mathrm{Fe}$ & $<87.7$ & 65300 & 65100 & 65100 & 65200 & 1 & 65200 & 65200 & 65200 & NA & 99800 & 94900 & 97400 & -1 \\
\hline $\mathrm{K}$ & $<834$ & $<921$ & $<755$ & $<860$ & $<<921$ & NA & $<<921$ & $<921$ & $<<921$ & NA & 20500 & 19500 & 20000 & -3 \\
\hline $\mathrm{La}$ & $<70.5$ & 534 & 543 & 533 & 537 & NA & 543 & 529 & 536 & NA & $<<228$ & $<203$ & $<<228$ & $\mathrm{NA}$ \\
\hline $\mathrm{Li}$ & $<36.1$ & $<39.9$ & $<32.7$ & $<37.2$ & $<39.9$ & NA & $<39.9$ & $<39.9$ & $<39.9$ & NA & 14400 & 13700 & 14100 & -6 \\
\hline $\mathrm{Mg}$ & $<12.0$ & 665 & 671 & 668 & 668 & 1 & 666 & 665 & 666 & $\mathrm{NA}$ & 5210 & 4970 & 5090 & -2 \\
\hline $\mathrm{Mn}$ & $<5.16$ & 14500 & 14400 & 14500 & 14500 & 1 & 14500 & 14500 & 14500 & NA & 14700 & 14000 & 14400 & -1 \\
\hline Mo & $<258$ & $<285$ & $<233$ & $<266$ & $<266$ & NA & $<285$ & $<285$ & $<285$ & NA & $<833$ & $<744$ & $<833$ & NA \\
\hline $\mathrm{Na}$ & $<373$ & 16200 & 16200 & 16000 & 16100 & 1 & 16100 & 16000 & 16000 & $\mathrm{NA}$ & 80900 & 77000 & 79000 & -7 \\
\hline $\mathrm{Ni}$ & $<125$ & 2170 & 2140 & 2150 & 2150 & 1 & 2110 & 2180 & 2140 & NA & 8520 & 8150 & 8340 & +1 \\
\hline $\mathrm{P}$ & $<1290$ & $<1430$ & $<1170$ & $<1330$ & $<1430$ & NA & $<1430$ & $<1430$ & $<1430$ & NA & $<4170$ & $<3730$ & $<4170$ & NA \\
\hline $\mathrm{Pb}$ & $<<909$ & 2950 & 2940 & 3010 & 2970 & $\mathrm{NA}$ & 2890 & 3100 & 3000 & NA & $<2940$ & $<2630$ & $<2940$ & NA \\
\hline S & $<382$ & $<422$ & $<346$ & $<394$ & $<422$ & NA & $\begin{array}{c}0.91 \\
\mathrm{mg} / \mathrm{L}\end{array}$ & $\begin{array}{c}0.82 \\
\mathrm{mg} / \mathrm{L}\end{array}$ & $\begin{array}{c}0.86 \\
\mathrm{mg} / \mathrm{L}\end{array}$ & $108 \%$ & $<1230$ & $<1100$ & $<1230$ & NA \\
\hline $\mathrm{Sb}$ & $<98.0$ & 225 & 222 & 223 & 223 & 1 & $\begin{array}{r}0.78 \\
\mathrm{mg} / \mathrm{L}\end{array}$ & $\begin{array}{c}0.74 \\
\mathrm{mg} / \mathrm{L}\end{array}$ & $\begin{array}{r}0.76 \\
\mathrm{mg} / \mathrm{L}\end{array}$ & $95 \%$ & 407 & 337 & 372 & NA \\
\hline $\mathrm{Si}$ & $<89.4$ & 1310 & 1170 & 1100 & 1200 & 9 & 1350 & 1270 & 1310 & NA & 3670 & 3840 & 3760 & $>-100$ \\
\hline $\mathrm{Sn}$ & $<796$ & $<879$ & $<721$ & $<821$ & $<879$ & NA & $<879$ & $<879$ & $<879$ & NA & $<2570$ & $<2300$ & $<2570$ & NA \\
\hline $\mathrm{Sr}$ & $<27.5$ & 954 & 957 & 943 & 951 & 1 & 950 & 950 & 950 & NA & 2260 & 2140 & 2200 & $>+100$ \\
\hline Th & $<30.9$ & $<34.2$ & $<28.0$ & $<31.9$ & $<34.2$ & NA & $\begin{array}{c}0.76 \\
\mathrm{mg} / \mathrm{L}\end{array}$ & $\begin{array}{c}0.74 \\
\mathrm{mg} / \mathrm{L}\end{array}$ & $\begin{array}{c}0.75 \\
\mathrm{mg} / \mathrm{L}\end{array}$ & $94 \%$ & $<100$ & $<89.3$ & $<100$ & NA \\
\hline $\mathrm{Ti}$ & $<12.0$ & $<13.3$ & $<10.9$ & $<12.4$ & $<13.3$ & NA & $<13.3$ & $<13.3$ & $<13.3$ & NA & 5330 & 4930 & 5130 & -26 \\
\hline $\mathrm{Tl}$ & $<177$ & $<196$ & $<160$ & $<183$ & $<196$ & NA & $\begin{array}{c}0.83 \\
\mathrm{mg} / \mathrm{L}\end{array}$ & $\begin{array}{c}0.80 \\
\mathrm{mg} / \mathrm{L}\end{array}$ & $\begin{array}{c}0.81 \\
\mathrm{mg} / \mathrm{L}\end{array}$ & $101 \%$ & $<572$ & $<511$ & $<572$ & NA \\
\hline $\mathrm{U}$ & $<85.9$ & $<95.0$ & 85.3 & 111 & $<111$ & NA & $\begin{array}{c}3.78 \\
\mathrm{mg} / \mathrm{L}\end{array}$ & $\begin{array}{c}3.67 \\
\mathrm{mg} / \mathrm{L}\end{array}$ & $\begin{array}{c}3.72 \\
\mathrm{mg} / \mathrm{L}\end{array}$ & $93 \%$ & $<278$ & $<248$ & $<278$ & NA \\
\hline $\mathrm{Zn}$ & $<17.2$ & 149 & 144 & 143 & 145 & 2 & 150 & 149 & 150 & NA & 171 & 170 & 170 & +6 \\
\hline $\mathrm{Zr}$ & $<24.1$ & $<26.6$ & $<21.8$ & $<24.8$ & $<24.8$ & NA & $<26.6$ & $<26.6$ & $<26.6$ & NA & 138 & 112 & 125 & $>-100$ \\
\hline b. & \multicolumn{14}{|c|}{$\begin{array}{l}\text { Elemental analysis concentrations of slurry simulant reported on wet slurry basis; The AY-102/C-106 simulant contained } 23.59 \pm 0.03 \% \\
\text { solids on oxide basis after heating at } 1100^{\circ} \mathrm{C} \text {. Elemental analysis concentrations of the LCS glass reported on dry powdered glass basis. } \\
\text { Concentrations of spiked elements reported in mg/L to facilitate comparison with the theoretical concentrations. Ag, } \mathrm{Cd}, \mathrm{S}, \mathrm{Sb} \text {, Th, and } \\
\mathrm{Tl} \text { were spiked at } 0.8 \mathrm{mg} / \mathrm{L} \text { of the solutions after digestion; U was spiked at } 4.0 \mathrm{mg} / \mathrm{L} \text { of the solutions after digestion. }\end{array}$} \\
\hline
\end{tabular}




\subsection{EXPERIMENTAL}

\subsubsection{General}

Liter bottles of simulants were mixed by placing them in a rotator used for the Toxicity Characteristic Leaching Procedure (TCLP) and rotating them at a rate of 30 revolutions per minute overnight. About $75 \mathrm{~mL}$ of the freshly-mixed slurry was then transferred by pouring into a wide-mouth $125 \mathrm{ml}$ plastic bottle. Before taking sub-samples for analytical work, the $125-\mathrm{mL}$ bottles were shaken manually for about 30 seconds, but no mixing was done as the 1.5-mL sub-samples were being taken. The excellent analytical precision on both the elemental analyses (Table 3-1 through Table 3-18) and weight \% oxide measurements (Table 3-22) attest to sample homogeneity. The sub-samples were removed with a plastic slurry pipette with about 1.5 inches cut off from the bottom to increase the pipette opening. The slurry was transferred to the pre-weighed digestion vessel and the sample weight recorded. All elemental analysis data in this report are on an "as-received" or slurry basis.

\subsubsection{Alkali Fusion Digestion Methods}

All digestions were performed manually in a fume hood. The first alkali fusion step was to evaporate the free water in the slurry to prevent it from reacting with alkali salts or splattering when placed in the high temperature muffle furnace. A drying oven set at $200{ }^{\circ} \mathrm{C}$ was used to evaporate the water. Because of the small sample size, excellent heat transfer properties of the metal crucible, and the high temperature of the drying oven, the water was evaporated from the samples in 15 minutes without splattering. The two HLW-2A simulants were dissolved in this form. The HLW-2B simulant was dissolved both as a dried powder and as a glass wafer. For digestions of glass samples, the HLW-2A simulant was first dried in a platinum crucible and then vitrified at $1100{ }^{\circ} \mathrm{C}$ for 30 minutes to form a thin glass wafer. The $\mathrm{Cs}_{2} \mathrm{CO}_{3}$ and $\mathrm{K}_{2} \mathrm{CO}_{3}$ fusions were carried out in the same platinum crucible and at the same temperature in which the glass wafers were made. For the $\mathrm{Na}_{2} \mathrm{O}_{2}$ fusion of glass wafers, which is incompatible with platinum ware, the glass wafers were transferred to a nickel crucible and the fusion carried out at $750{ }^{\circ} \mathrm{C}$.

The ratio of alkali flux reagent to dry sample was approximately 10:1 for all types of fluxes. The recipes for the typical $5 \mathrm{~g}$ of alkali flux used were:

- $\mathrm{Na}_{2} \mathrm{O}_{2}$ only- $5 \mathrm{~g} \mathrm{Na}_{2} \mathrm{O}_{2}$

- $\mathrm{Na}_{2} \mathrm{O}_{2} / \mathrm{NaOH}-3.5 \mathrm{~g} \mathrm{Na}_{2} \mathrm{O}_{2} / 1.5 \mathrm{~g} \mathrm{NaOH}$

- $\mathrm{CsOH}$ only- $5 \mathrm{~g} \mathrm{CsOH}$ (commercial $\mathrm{CsOH}$ is available as the monohydrate $\left.\mathrm{CsOH} \cdot \mathrm{H}_{2} \mathrm{O}\right)$

- $\mathrm{Cs}_{2} \mathrm{CO}_{3} / \mathrm{CsOH}$ - Dissolve $0.5 \mathrm{~g} \mathrm{CsOH}$ in $2 \mathrm{~mL}$ water, add to slurry sample and dry; add $5 \mathrm{~g} \mathrm{Cs}_{2} \mathrm{CO}_{3}$ to the dry sample/CsOH residue

- $\mathrm{Cs}_{2} \mathrm{CO}_{3}$ only-5 $\mathrm{g} \mathrm{Cs}_{2} \mathrm{CO}_{3}$

- $\mathrm{KOH} / \mathrm{KNO}_{3}-4.8 \mathrm{~g} \mathrm{KOH} / 0.2 \mathrm{~g} \mathrm{KNO}_{3}$-both as powders

A muffle furnace was used to perform all fusion digestions. The furnace was heated to the desired temperature and the heating time was measured from the time that the furnace re-equilibrated to the pre-set temperature. Ten minutes of flux time was used for all fusions. 
After removal from the furnace, crucibles were placed on clean Kevlar boards to cool. The crucibles were then dropped into either $500 \mathrm{~mL}$ or $1000 \mathrm{~mL}$ wide-mouth bottles that had been pre-charged with a known volume of water/ $30 \%$ hydrogen peroxide mixture to dissolve the alkali salts and to liberate the flux residue from the crucible bottom. A solution of 1.6 $\mathrm{M} \mathrm{HNO}_{3}$ was then added to dissolve metal hydroxides. Dropping the entire crucible into a wide-mouth bottle is a simple technique that reduces the possibility of splattering or spilling the sample which can occur when water is added to the crucible followed by transfer of the slurry to a volumetric flask. This technique also has convenience and speed advantages since the water/hydrogen peroxide mixture and acid solutions can be accurately pre-measured outside the shielded cells to yield a final known volume by simply pouring the pre-measured reagents into the large bottle. Since the outside of the crucible comes into contact with the analytical solution, a modicum of care must be taken to keep the surfaces that the crucibles touch clean. We brushed the crucible bottom across a clean cloth to remove any fibers that might be introduced from the muffle furnace floor or Kevlar pad before dropping the crucibles into the wide-mouth bottle. We also had spare ceramic floors to the muffle furnace (the cost of these is about $\$ 25$ for the model furnace that we used) in case a crucible was spilled inside the muffle furnace. The use of a rack to hold the crucibles during transfer into and out of the muffle furnace minimizes the spill potential and also helps keep the outside of the crucible clean.

A rate-limiting step in the work-up of alkali fusion digestions is the dissolution of the alkali salts/metal hydroxide pellet that forms in the crucible bottom after the flux cools. Although the alkali residue would dissolve faster if acid were used initially to dissolve the residue, in some conditions we have observed $\mathrm{SiO}_{2}$ precipitate irreversibly from strong acid solutions and yield Si determinations that are biased low. The solution can be rapidly heated to speed dissolution by chemical decomposition of $\mathrm{H}_{2} \mathrm{O}_{2}$ in the strongly alkaline solution. We normally add 2-3 drops of $\mathrm{H}_{2} \mathrm{O}_{2}$ as a chemical oxidant, but by adding as much as $5 \mathrm{~mL}$ of $\mathrm{H}_{2} \mathrm{O}_{2}$, the solution will warm rapidly to help dissolve the alkali (which in turn warms the solution as it dissolves). This technique reduces the time needed to dissolve the alkali residue and eliminates the need to vigorously agitate the bottle to promote alkali dissolution.

Completely clear digestions were accomplished only by the sodium peroxide fusion (for both the HLW-2A and HLW-2B matrices) and by the cesium carbonate fusions (on the HLW-2B matrix, as both a dry powder and after vitrifying into glass wafers). $\mathrm{HNO}_{3}$ was effective for both the sodium peroxide method and the cesium carbonate method. Although nitric acid was initially used for the cesium hydroxide and potassium hydroxide fusions, considerable residual solids were observed and the digestions were repeated using hydrochloric acid. Fewer solids were observed when $\mathrm{HCl}$ was used, but completely clear solutions were not immediately obtained by either the cesium hydroxide fusion or the potassium hydroxide fusion on the HLW-2A matrix. The amount of residual solids lessened upon sitting in the acid solution, but since speed was of the essence, we could not afford the luxury of waiting for dissolution of the more refractory sludge particles. A few drops of $30 \% \mathrm{H}_{2} \mathrm{O}_{2}$ were usually needed after the acid addition to create a clear solution from the sodium peroxide fusions (the $\mathrm{H}_{2} \mathrm{O}_{2}$ decomposes so rapidly in caustic that it is usually depleted before the acid addition, necessitating, in these cases, addition of 2-4 drops as a chemical oxidant). 
The initial dilution volume after the alkali fusion digestions was either $500 \mathrm{~mL}$ or $525 \mathrm{~mL}$. The initial dilution was diluted 5-10 fold with de-ionized water to reduce the dissolved solids content and to reduce the concentration of the major elements to near the concentration range of ICP-AES calibration standards.

The detailed procedure for sodium peroxide fusion method in nickel crucibles is shown in Table 3-19. The other alkali fusion methods are outlined in Table 2-1.

\subsubsection{Mixed-Acid Digestion Methods}

The externally heated mixed-acid methods, the $\mathrm{HF}-\mathrm{HCl}$ method and the $\mathrm{HCl}_{-} \mathrm{HNO}_{3}$ (aqua regia) method, were carried out in CEM Corporation 120 PFA Teflon Microwave Vessels with Cap Relief Valve, Part Number-CEM 221001. These vessels are designed for use in a microwave oven but can be used in a conventional heating oven if the temperatures are moderate. A CEM Corporation capping station was used to tighten the caps to the prescribed torque after the vessels were charged with sample and acids. After heating and diluting the solutions to $500 \mathrm{~mL}$, considerable white solids were left from both digestions. The solutions were filtered through a 0.45 micron porosity filter and serially diluted 5-10 fold with deionized water before ICP-AES analysis.

The warm mixed-acid method was carried out in $500 \mathrm{~mL}$ wide-mouth bottles. The slurry sample was weighed in $30 \mathrm{~mL}$ wide-mouth Nalgene ${ }^{\mathrm{TM}}$ plastic bottles and then the entire bottle was dropped into the $500 \mathrm{~mL}$ wide-mouth bottle. This technique was used rather than weighing the slurry directly into the $500 \mathrm{~mL}$ bottles because it is anticipated that this technique will be more convenient to perform remotely. Sequential addition of concentrated $\mathrm{HNO}_{3}$ and $\mathrm{H}_{2} \mathrm{O}_{2}$ to the slurry resulted in a warm, frothy solution from the chemical decomposition of $\mathrm{H}_{2} \mathrm{O}_{2}$ in acid solution coupled with heat of dissolution/neutralization of the caustic sample. Addition of $\mathrm{HCl}$ to the warm solution helped to dissolve sludge particles, but white solids remained. After diluting the solution to a final volume of $500 \mathrm{~mL}$, the solution was filtered through a 0.45 micron porosity filter to clarify the solution prior to ICP-AES analysis. For these samples, a 5-fold serial dilution was performed. For the Phase II Timeand-Motion study, a single dilution to $1000 \mathrm{~mL}$ will performed to save time by obviating the need for a serial dilution to measure $\mathrm{Na}$ and $\mathrm{Ni}$. The procedure discussed in Table 3.20 specifies a final dilution to $1000 \mathrm{~mL}$ for this reason.

The detailed procedure for the Warm Acid Method is shown in Table 3-20. The other mixed acids methods are outlined in Table 2-1. 


\section{WSRC-TR-2005-00169, REVISION 0 SRNL-RPP-2005-00023, REVISION 0}

\section{Table 3-19. Procedure for Sodium Peroxide Fusion Method}

Step \#
1
2

\section{Description}

Preheat the cell drying oven to $200{ }^{\circ} \mathrm{C}$ and the muffle furnace to $750{ }^{\circ} \mathrm{C}$.

Transfer 1-1.5 mL of slurry into pre-weighed $50 \mathrm{~mL}$ Ni crucible. Repeat for all 8 samples and carry these samples through the fusion procedure.

Comment: A slurry pipette with about 1.5 inches cut off the bottom to increase the opening is used to transfer the sample. It is important that the slurry sample be deposited on the bottom of the crucible. If sample is deposited high on the crucible sides, the molten $\mathrm{Na}_{2} \mathrm{O}_{2}$ may not come into contact with the sample and incomplete digestion of some compounds may result. If necessary, guides made from plastic funnels with some of the stem cut off can be used to help deposit the sample on the crucible bottom.

Record the sample weight in the data sheet or notebook.

Place the crucibles in the drying oven, close the door, and heat for 15 minutes.

Comment: The water should be evaporated from the sample in this time.

Remove the crucibles and add 5 grams of granular $\mathrm{Na}_{2} \mathrm{O}_{2}$ on top of the dry sludge.

Comment: It is unnecessary to intimately mix the dry powder with $\mathrm{Na}_{2} \mathrm{O}_{2}$ which is very aggressive and attacks chunks of dried powder.

Place the crucibles in the furnace. Heat for 10 minutes after the furnace temp re-equilibrates to $750{ }^{\circ} \mathrm{C}$. The $\mathrm{Na}_{2} \mathrm{O}_{2}$ should melt and create a black molten pool.

Remove crucibles from furnace and let cool for 10 minutes on a clean Kevlar board or similar nonflammable material.

Drop the entire crucible into the wide-mouth $1000 \mathrm{~mL}$ bottle that has been pre-charged with a solution of $245 \mathrm{~mL}$ of de-ionized water and $5 \mathrm{~mL}$ of $30 \%$ hydrogen peroxide.

If the crucible does not situate itself on its side, gently rock the wide-mouth bottle until the crucible is on its side to facilitate contact with the $\mathrm{H}_{2} \mathrm{O} / \mathrm{H}_{2} \mathrm{O}_{2}$ solution.

Comment: One of the rate-limiting steps of the sodium peroxide fusions is the dissolution of the alkali flux residue. The rapid decomposition of the $\mathrm{H}_{2} \mathrm{O}_{2}$ in caustic solution creates a warm, frothy solution that hastens the dissolution of the alkali flux. Mix briefly by swirling and let stand for 5 minutes. The inside of the Ni crucible bottoms should be clean at this point, although it is impossible to confirm this without removing the crucible. Repeated checks with non-radioactive simulants showed in every case that the Ni crucible bottom was clean and that the entire flux material had been released to the caustic solution after 5 minutes. 
WSRC-TR-2005-00169, REVISION 0

SRNL-RPP-2005-00023, REVISION 0

\section{Table 3-19. Procedure for Sodium Peroxide Fusion Method - continued \\ Step \# \\ Description}

9

Slowly add $250 \mathrm{~mL}$ of $1.6 \mathrm{M} \mathrm{HNO}_{3}\left(25 \mathrm{~mL}\right.$ of concentrated $\mathrm{HNO}_{3}$ diluted to $250 \mathrm{~mL}$ in a plastic volumetric flask) to create final volume of $500 \mathrm{~mL}$. Cap the bottle and swirl to mix, then uncap the bottle.

Comment: The solution will either be black or green at this point, depending on whether hydrogen peroxide is still present in the solution. Frequently, the hydrogen peroxide decomposes so quickly in caustic solution that it is depleted and the solution is black in color. To generate the green color from $\mathrm{Ni}$ ions, 2-4 drops of $30 \%$ hydrogen peroxide added to the acid solution should be sufficient. Take care not to add excessive hydrogen peroxide as gas evolution from decomposition of hydrogen peroxide in acid solution could pressurize a completely sealed bottle. Although this condition usually results in only a slightly distorted bottle, it can be avoided by minimizing the hydrogen peroxide. Sodium peroxide fusions should be ready for serial dilutions within 5 minutes after acid addition.

Serially dilute with DI water prior to ICP-AES analysis.

Comment: A 5-fold or 10-fold dilution is suitable for subsequent ICP-AES analysis.

The $1000 \mathrm{~mL}$ wide-mouth bottle can be rinsed with de-ionized water, allowed to dry, and re-used indefinitely to minimize cell waste. The $250 \mathrm{~mL}$ portions of de-ionized water and $1.6 \mathrm{M} \mathrm{HNO}_{3}$ can also be prepared easily in the cells to minimize cell waste and the need for introducing reagents into the cells. 


\section{WSRC-TR-2005-00169, REVISION 0 SRNL-RPP-2005-00023, REVISION 0}

\section{Table 3-20. Warm Mixed-Acid Method}

\section{Step \\ \#}

1 Transfer 1-1.5 mL of slurry into a pre-weighed or tared $30 \mathrm{~mL}$ wide-mouth plastic bottle. Repeat for all 8 samples and carry these samples plus standards and blanks through the entire digestion procedure.

Comment: A plastic transfer pipette with about 1.5 inches cut off the bottom to increase the opening is used to transfer the sample. The sample is weighed into a smaller bottle for cell operator convenience (easier to move a small bottle to the cell balance pan than the $1000 \mathrm{~mL}$ bottle).

2 Record sample weight in data sheet or notebook.

3 Drop the $30 \mathrm{~mL}$ plastic bottle into a $1000 \mathrm{~mL}$ wide-mouth plastic bottle.

Comment: The large bottle virtually eliminates sample loss through splattering. The $1000 \mathrm{~mL}$ bottle is used so that a large initial dilution can eliminate the need for serial dilutions, a time-consuming step when performed remotely.

Add $15 \mathrm{~mL}$ con. $\mathrm{HNO}_{3}$. Swirl the $1000 \mathrm{~mL}$ bottle to get the acid in contact with the sample. Add $5 \mathrm{~mL} 30$ $\% \mathrm{H}_{2} \mathrm{O}_{2}$. The solution rapidly becomes warm and frothy from the acid decomposition of $\mathrm{H}_{2} \mathrm{O}_{2}$ together with heat of decomposition/neutralization of the highly caustic sample mixed with strong acid. Let the reaction proceed about 2 minutes before adding the concentrated $\mathrm{HCl}$ in the next step.

Comment: The large amount of $\mathrm{H}_{2} \mathrm{O}_{2}$ is added not for the usual reason of being a strong oxidizing reagent. Rather, the decomposition of $\mathrm{H}_{2} \mathrm{O}_{2}$ in strong acid solution in the presence of the sample provides rapid chemical warming of the acid mixture and makes the $\mathrm{HCl}$ strike in the next step more effective. An external heating source for higher temperatures and more prolonged heating can be substituted for this technique should subsequent measurements show that the technique does not fully dissolve $\mathrm{Na}$ and $\mathrm{Ni}$ in actual Hanford waste tank samples.

All reagent volumes are accurately pre-measured in the laboratory and then transferred to the cells to minimize cell operations and analytical time.

5 Add $5 \mathrm{~mL}$ con. $\mathrm{HCl}$ to the warm nitric/hydrogen peroxide solution. Swirl each bottle for $10-15$ seconds to promote mixing. Let stand for 5 minutes.

Comment: Additional heat evolution will rapidly occur if peroxide is still present in the solution. Most if not all of the iron-containing sludge particles will dissolve with this method. Since $\mathrm{SiO}_{2}$ is present in all samples, complete digestion of the sample is impossible with this acid mixture and must be removed by filtration to avoid plugging the ICP nebulizer.

The addition of $\mathrm{HCl}$ may unnecessary to measure $\mathrm{Na}$ and $\mathrm{Ni}$, but it does dissolve more of the sample and lessens the chances that analytes are sequestered in solid particles. It is possible that reliable $\mathrm{Na}$ and $\mathrm{Ni}$ measurements can be obtained with less $\mathrm{HCl}$, or perhaps no $\mathrm{HCl}$ at all, to minimize cell corrosion from $\mathrm{HCl}$ attack on metal surfaces.

Add $975 \mathrm{~mL}$ de-ionized water to create a final volume of $1000 \mathrm{~mL}$.

Comment: A large dilution at this step encourages dissolution of $\mathrm{Na}$ salts and reduces the $\mathrm{Na}$ concentration for convenient ICP-AES measurements with typical calibration protocols without a serial dilution step.

7 Cap the $1000 \mathrm{~mL}$ bottle and shake for 15 seconds to mix. Let stand 5 minutes before filtration.
Filter about $20 \mathrm{~mL}$ of the solution to remove remaining solids before ICP-AES analysis.

Comment: A convenient filtration system is a $10 \mathrm{~mL}$ plastic disposable syringe with the plunger removed and fitted with a 0.45 micron or 0.70 micron porosity filter disk. The solutions can be filtered quickly with a gravity feed, although a vacuum box such as the Speedmate ${ }^{\mathrm{TM}}$ system may also be considered for use. Using the syringe plunger to push the solution through the filter is too inconvenient for shielded cell use. 


\subsubsection{ICP-AES Experimental}

All ICP-AES determinations were performed using a JY 170 C ICP-AES spectrometer with a 1-meter focal length monochromator and a 0.5 -meter focal length polychromator. A 3-point calibration protocol was used based on analyzing a blank solution, a $5.00 \mathrm{mg} / \mathrm{L}$ concentration solution of elements, and a $10.00 \mathrm{mg} / \mathrm{L}$ concentration solution for most elements. QC check standards were analyzed after sample analysis. The closing QC check standards can differ by no more than $10 \%$ from the standard value without a QC flag being issued on the data report. The principal variance from the $\pm 10 \%$ closing QC criterion in the data in this report was from $\mathrm{U}$, which in some cases differed by $14 \%$ from the initial calibration.

The ICP-AES analytical line wavelengths used for the analysis of the WTP simulants are shown in Table 3-21.

Table 3-21. ICP-AES Wavelengths Used for Elemental Determinations

\begin{tabular}{lc} 
Element & Wavelength (nm) \\
$\mathrm{Ag}$ & 328.068 \\
$\mathrm{Al}$ & 308.215 \\
$\mathrm{~B}$ & 208.959 \\
$\mathrm{Ba}$ & 230.424 \\
$\mathrm{Ca}$ & 393.367 \\
$\mathrm{Cd}$ & 226.502 \\
$\mathrm{Ce}$ & 399.924 \\
$\mathrm{Cr}$ & 205.559 \\
$\mathrm{Cu}$ & 324.754 \\
$\mathrm{Fe}$ & 259.940 \\
$\mathrm{~K} \mathrm{Mono}$ & 766.490 \\
$\mathrm{La}$ & 408.672 \\
$\mathrm{Li}$ & 670.784 \\
$\mathrm{Mg}$ & 279.553 \\
$\mathrm{Mn}$ & 257.610 \\
$\mathrm{Mo}$ & 202.032 \\
$\mathrm{Ni}$ & 216.556 \\
$\mathrm{P}$ & 178.225 \\
$\mathrm{~Pb}$ & 220.353 \\
$\mathrm{~S} \mathrm{Mono}$ & 180.676 \\
$\mathrm{Sb}$ & 206.833 \\
$\mathrm{Si}$ & 251.611 \\
$\mathrm{Sn}$ & 189.926 \\
$\mathrm{Sr}$ & 407.771 \\
$\mathrm{Th}$ & 283.232 \\
$\mathrm{Ti}$ & 334.940 \\
$\mathrm{Tl}$ & 351.924 \\
$\mathrm{U} \mathrm{Mono}$ & 385.958 \\
$\mathrm{Y} \mathrm{Mono}$ & 371.029 \\
$\mathrm{Zn}$ & 213.856 \\
$\mathrm{Zr}$ & 349.621 \\
& \\
\hline
\end{tabular}




\subsubsection{Measurement of Wt. \% Oxide of Simulants}

All elemental analysis results in this report are on a wet slurry basis. In the WTP, elemental results will be reported on an oxide basis which means that the wt. \% oxides will have to be measured concurrently with the digestions and elemental analysis in order to obtain a slurryto-oxide conversion factor. The wt. \% oxides of each of the three simulants tested were measured by first evaporating the water from approximately $1.5 \mathrm{~mL}$ of slurry followed by heating the powder to constant weight at $1100^{\circ} \mathrm{C}$ in platinum crucibles. The individual wt. $\%$ oxide measurements for the AY-102/C-106, AZ-101, and AY-102/C-106 plus glass formers/glass modifiers are shown in Table 3-22. More measurements of the wt. $\%$ oxide of the AY-102/C-106 plus glass-formers/glass-modifiers were made because the slurry was vitrified to create glass samples for testing digestion procedures.

Table 3-22. Wt. \% Oxides Measurements for WTP Simulants

\begin{tabular}{|c|c|c|}
\hline $\begin{array}{l}\text { AY-102/C-106 } \\
\text { HLW-2A Simulant } \\
\text { (wt. \% oxides) }^{\text {a }}\end{array}$ & $\begin{array}{l}\text { AZ-101 } \\
\text { HLW-2A Simulant } \\
\text { (wt. \% oxides) }^{\mathrm{a}}\end{array}$ & $\begin{array}{l}\text { AY-102/C-106 + } \\
\text { Glass Formers } \\
\text { HLW-2B Simulant } \\
\text { (wt. \% oxides) }^{\text {a }}\end{array}$ \\
\hline 23.56 & 20.20 & 36.84 \\
\hline 23.56 & 20.29 & 38.88 \\
\hline 23.63 & 20.19 & 36.90 \\
\hline 23.60 & 20.29 & 36.91 \\
\hline \multirow[t]{7}{*}{23.58} & 20.20 & 37.01 \\
\hline & & 36.94 \\
\hline & & 36.96 \\
\hline & & 36.95 \\
\hline & & 36.97 \\
\hline & & 36.89 \\
\hline & & 36.92 \\
\hline Avg. $=23.59$ wt. $\%$ & Avg. $=20.23$ wt. $\%$ & Avg. $=36.92$ wt. $\%$ \\
\hline $1 \sigma=0.03$ wt. $\%$ & $1 \sigma=0.05$ wt. $\%$ & $1 \sigma=0.05$ wt. $\%$ \\
\hline
\end{tabular}

a. Wt. \% oxides measured at $1100{ }^{\circ} \mathrm{C}$ in platinum crucibles. 
WSRC-TR-2005-00169, REVISION 0

SRNL-RPP-2005-00023, REVISION 0

\subsubsection{Use of Matrix Spikes}

Two different matrix spike protocols were used.

\subsubsection{Use of Spike Solution with Ag, Cs, S, Sb, Th, Tl, and U Added After Digestions}

The first protocol was to add a stock solution consisting of $\mathrm{Ag}, \mathrm{Cd}, \mathrm{S}, \mathrm{Sb}, \mathrm{Th}, \mathrm{Tl}$, and U made from single-element ICP-AES standards to a solution of the dissolved sample (the first replicate digestion was arbitrarily chosen to be spiked). The concentration of the stock solution was $1.0 \mathrm{mg} / \mathrm{L}$ for $\mathrm{Ag}, \mathrm{Cd}, \mathrm{S}, \mathrm{Sb}, \mathrm{Th}$, and Tl. The concentration of $\mathrm{U}$ in the stock solution was $5.0 \mathrm{mg} / \mathrm{L}$. A higher concentration of $U$ was used because it is anticipated that $U$ will be at higher concentrations in the high-level waste. Twenty $\mathrm{mL}$ of this stock solution was used to dilute $5 \mathrm{~mL}$ of the original digestion solution to create a 5-fold dilution of the original digestion solution, analogous to the 5-fold dilution with de-ionized water performed prior to ICP-AES analyses. The theoretical concentration of the spiked elements in this solution was $0.80 \mathrm{mg} / \mathrm{L}$ for $\mathrm{Ag}, \mathrm{Cd}, \mathrm{S}, \mathrm{Sb}, \mathrm{Th}$, and $\mathrm{Tl}$ and $4.0 \mathrm{mg} / \mathrm{L}$ for U. The spike was performed in duplicate and analyzed in sequence with the non-spiked solutions. If the spiked elements had a measurable concentration in the non-spiked solution, the average of these measured concentrations was subtracted from the spiked concentration to yield a net spike concentration from which the percent spike recovery was calculated.

The elements Ag, Cd, S, Sb, Th, Tl, and U were selected for the spike addition primarily because these elements are currently on the list of required WTP elements, but are not in the Analytical Reference Glass-1 standard (see following section). The spike experiment provided a way to assess the chemical compatibility of the elements with the digestion matrix (that is, to check for precipitation problems that would be manifested as low recoveries).

From the ICP-AES perspective, the spike experiments help to check for spectral interferences either from the matrix elements on the spiked elements or vice versa. The concentrations of non-spiked elements are shown both with and without the spiked elements present in the data tables. In particular, it was of interest to determine if the $4.0 \mathrm{~g} / \mathrm{L} \mathrm{U}$ (an element with an especially complex emission spectrum) in the analytical solution would spectroscopically affect the other analytes. Since there were no significant differences in the measurements spiked versus non-spiked, the concentration of $U$ is not high enough to create problems in this analytical matrix for measuring the important process control elements

The seven-element spike protocol was used for the first seven sets of digestion methods tested. Table 3-1, Table 3-6, Table 3-7, Table 3-8, Table 3-11, Table 3-17, and Table 3-18 show the elemental concentrations in units of $\mu \mathrm{g} / \mathrm{g}$ except for the spiked elements, which are shown in units of $\mathrm{mg} / \mathrm{L}$ to facilitate the comparison of the measured concentration versus theoretical. The percent recoveries of the spike elements are also shown in the tables. 
The percent recovery was good for $\mathrm{Cd}, \mathrm{S}, \mathrm{Sb}, \mathrm{Th}$, and $\mathrm{Tl}$ on all seven digestions matrices. $\mathrm{U}$ recoveries were, in general, over $75 \%$ but less than expected considering the high solubility of $U$ salts in acid solution. It is possible that the less than quantitative percent recoveries reflect the nature of the relatively weak $U$ analytical line used in ICP-AES measurements rather than precipitation of $\mathrm{U}$. In fact, the closing QC analysis of check standards after sample analysis showed that the variance from the accepted value was a much as $14 \%$. The Ag recovery was good for the sodium peroxide fusion matrix with $\mathrm{HNO}_{3}$ uptake (Table 3-1), and poorer for the methods that used $\mathrm{HCl}$. Precipitation of $\mathrm{AgCl}$ in the high-chloride matrix of these digestion methods is a reasonable chemical explanation for the poor recoveries of $\mathrm{Ag}$.

\subsubsection{Use of Spike Solution with Y Added Before Digestions}

The second spike protocol used was addition of $1.0 \mathrm{~mL}$ of a $10,000 \mathrm{mg} / \mathrm{L}$ stock solution of $\mathrm{Y}$ to the slurry samples prior to the digestion. After digestions and dilutions, the $\mathrm{Y}$ concentration in the solutions analyzed by ICP-AES was between 2.0 and $4.0 \mathrm{mg} / \mathrm{L}$. This protocol was applied to 11 sets of digestions and the results are shown in Table 3-2, Table 3-3, Table 3-4, Table 3-5, Table 3-9, Table 3-10, Table 3-12, Table 3-13, Table 3-14, Table 3-15, and Table 3-16. The percent recovery of $Y$ was excellent for all sample preparation methods except the $\mathrm{KOH}$ fusion in $\mathrm{Zr}$ crucibles used on the AZ-101 simulant. The reason for the poor Y recovery in this matrix is not known at this time.

Review of the elemental analysis data revealed that the $\mathrm{Zr}$ values were always higher for the Y spiked solutions versus non-spiked solutions. Tests with single-element Y standards demonstrated that $Y$ has an approximate $7 \%$ spectral interference bias on the $\mathrm{Zr} 349.621 \mathrm{~nm}$ analytical line. This bias was mathematically corrected by measuring the $Y$ concentration in the spike solution and subtracting the $\mathrm{Zr}$ signal resulting from $\mathrm{Y}$ spectral interference.

\subsubsection{Appraisal of Spikes for Digestions/ICP-AES Elemental Analysis}

The use of spikes to measure analytical reliability is effective in many applications. However, in the opinion of the principal investigator, spikes used in digestions/ICP-AES elemental analysis do not have enough technical merit to justify the effort involved with performing them as part of the routine analytical protocol in the WTP. Adding soluble species to high-level waste solids obviously does not measure the effectiveness of digestions of the solid material in the waste. Spike recoveries of soluble elements could be excellent, whereas the analysis of the actual material in the waste tank could be low due to incomplete digestion. In this case, the spike recovery experiment would give a false reading of the data quality. Another factor against using matrix spikes is that it would add a tedious and timeconsuming step for shielded cell operators.

The WTP sample compositions will be reasonably stable for months at a time as particular sludge tanks are processed. Given this and the fact that as many as 8 replicate analyses will be made on each sample to measure analytical quality, there seems little to be gained by adding matrix spikes to the analytical protocol. 


\subsubsection{Use of Laboratory Control Standard (LCS)}

The laboratory control standard (LCS) used was the Analytical Reference Glass-1 (ARG-1) [9]. The elemental composition of ARG-1 glass standard, excluding oxygen, is shown in Table 3-23. The ARG-1 glass was characterized both through a commercial laboratory specializing in glass analyses, the Corning Engineering Laboratory Services (CELS), and through an analytical round robin involving seven laboratories. Very slight differences in elemental analyses were observed between the CELS and the composite results from the laboratories participating in the round robin. In general, the CELS values were slightly higher than the composite results. Since the CELS results were considerably more precise than the composite results, and since the CELS results yield a sum of oxides at $100.07 \%$ versus the composite sum of oxides at $99.48 \%$, SRNL has historically used the CELS values as the standard values.

Table 3-23. Elemental Composition of ARG-1 Reference Glass

$\begin{array}{cc}\text { Element } & \text { \% Element in Glass } \\ \mathrm{Al} & 2.50 \\ \mathrm{~B} & 2.69 \\ \mathrm{Ba} & 0.08 \\ \mathrm{Ca} & 1.02 \\ \mathrm{Cr} & 0.06 \\ \mathrm{Cu} & 0.003 \\ \mathrm{Fe} & 9.79 \\ \mathrm{~K} & 2.26 \\ \mathrm{Li} & 1.49 \\ \mathrm{Mg} & 0.52 \\ \mathrm{Mn} & 1.46 \\ \mathrm{Na} & 8.52 \\ \mathrm{Ni} & 0.827 \\ \mathrm{P} & 0.11 \\ \mathrm{Si} & 22.4 \\ \mathrm{Sr} & 0.003 \\ \mathrm{Ti} & 0.69 \\ \mathrm{Zn} & 0.016 \\ \mathrm{Zr} & 0.096\end{array}$


The ARG-1 glass was dissolved in duplicate and analyzed concurrently with the WTP simulants. The average of the duplicate analyses was compared with standard value and a percent error assigned from the difference between the measured and standard elemental analysis value, and a sign to the error depending on whether the LCS elemental analysis was less or more than the standard value. The duplicate LCS analyses, the average of the duplicate analyses, and the error percentages are shown in the last four columns of Table 3-1 through Table 3-18.

LCS analyses in these tests were similar to the SRNL historical experiences with dissolving the ARG-1 glass with various techniques and analyzing the solutions with ICP-AES techniques. $\mathrm{Al}$ and $\mathrm{B}$ values are almost always biased low versus the standard value, even when the digestion is successful and no solids remain after digestion. The mechanism for this bias is not known, but the magnitude of the bias is low enough that it is of little practical consequence for most applications.

Sr determinations in the ARG-1 glass standard were biased significantly higher than the $30 \mu \mathrm{g} / \mathrm{g}$ that would be expected based on the standard value of approximately $0.003 \mathrm{wt}$. \%. Sr determinations averaged about $2400 \mu \mathrm{g} / \mathrm{g}$, or almost 100 times the expected value. Spectral interference checks showed that Ca produces about $5 \%$ interference on the $\mathrm{Sr} 407.771 \mathrm{~nm}$ analytical line used at SRNL. Since ARG-1 contains about 10,200 ug/g Ca, this level of Ca interference produces a $\mathrm{Sr}$ signal of about $500 \mathrm{ug} / \mathrm{g}$, which obviously precludes accurate determinations of Sr in ARG-1 glass standard, but does not explain the source of the additional 5-fold high bias. The Sr concentration in ARG-1 glass is so low that is of little practical use except as an indicator that low levels of Sr could not be measured accurately without spectroscopic experiments to determine a more appropriate analytical line for this matrix.

The $\mathrm{Zn}$ values were biased high as well, though not as severely biased as the $\mathrm{Sr}$ values. Analyses of single-element ICP-AES standards to determine the source and magnitude of the spectral interference have not yet pinpointed the source of error. As with $\mathrm{Sr}$ determinations, the $\mathrm{Zn}$ concentration in ARG-1 glass standard is too low to indicate digestion/ICP-AES analytical quality.

Determinations of the remaining LCS elements were either good or predictably poor as a function of the adequacy of the method to dissolve glass. For example, the hot aqua regia digestion method data (Table 3-18) shows the expected poor results for Si since aqua regia will dissolve little $\mathrm{Si}$ in glass. Hot aqua regia does with time leach out most of the components in the fine powder form of the glass. Accurate determinations of the soluble elements are possible despite the fact that large amounts of solid $\mathrm{SiO}_{2}$ remain after the leach.

The glass form of the LCS is completely inappropriate for the warm acidification method (Table 3-16) used to measure the $\mathrm{Na}$ and $\mathrm{Ni}$ not obtainable from sodium peroxide fusions carried out in Ni crucibles. To provide at least a QC check on the ICP-AES analyses, the solutions from the sodium peroxide fusion in nickel crucibles were analyzed concurrently with the solutions from the warm acidification of the slurry simulant. 


\subsubsection{Appraisal of LCS Use for Quality Checks}

Concurrent analysis of a matrix standard is an important element of the QC protocol. Accurate analysis of matrix standards requires that all operations be done properly, including accurate handling and weighing of the standard, complete digestion of those elements to be measured, and reliable ICP-AES instrumental analysis of the solutions.

It is important that the physical form of the LCS match that of the sample to obtain maximum benefits from carrying the LCS through the analytical procedures. This is particularly true when the sample is dissolved since the overall analytical method quality can be no better than the quality of the digestion. The ARG-1 standard was used as the LCS in these tests because it is used as such at the SRS Defense Waste Processing Facility and at both SRNL and PNNL for research samples. Since excellent analyses were obtained on slurry samples without converting them to glass, the time-saving advantages of analyzing the "as-received" slurries have convinced us that this is the best analytical approach. Therefore, the LCS should be in slurry form instead of glass. We recommend that a sufficient volume of slurry simulants be produced, pre-dispensed into sample bottles, and set aside in air-tight conditions until used in the WTP. One concept that should be considered is to charge the slurry simulants into process sample vials and then transfer them to the analytical shielded cells through the pneumatic transfer system. This system could theoretically be used to make the LCS blind standards.

\subsubsection{Sample Tracking}

Analytical samples from the tests on WTP simulants were tracked through the Analytical Development Section Laboratory Information Management System. A typical analytical test included a digestion blank, 3-5 replicate analyses of the simulant, 1-3 analyses of simulants with matrix spikes added, and 2 duplicate analyses of the LCS. Each sample was assigned a

unique number. The analytical data from the ICP-AES was stored permanently in electronic files at SRNL.

\subsubsection{Statistical Analysis}

Statistical analysis of the ICP-AES data as a function of the digestion methods for the AY-102/C-106 simulant [12], the AZ-101 simulant [13], and the AY-102/C-106 with glass formers simulant [14], was performed by T.B. Edwards of the Statistical Consulting Section of SRNL. These reports should be consulted for statistical methods and software details. 


\subsection{FUTURE WORK}

Future work will consist of testing the recommended analytical scheme with simulants in the SRNL Shielded Cell Facility. The work will involve performing a Time-and-Motion study to measure the time required to perform the recommended analytical scheme with manipulators. Wet chemistry digestions and ICP-AES elemental analyses of glass samples prepared with actual Hanford high-level waste will be used to support LA-ICP-AES development work on radiological glass samples. Additional non-radiological tests will be performed to help develop a single digestion scheme applicable to both HLW-2A and HLW-2B samples. 
WSRC-TR-2005-00169, REVISION 0

SRNL-RPP-2005-00023, REVISION 0

\subsection{REFERENCES}

[1] Herman, C. C., C. J. Coleman, and K. E. Zeigler, "Task Technical and Quality Assurance Plan for Conventional Wet Chemistry and Laser Ablation ICP-AES Development," WSRC-TR-2004-00447, SRNL-RPP-2004-00073, Revision 0, October 2004.

[2] "WSRC-SRNL NTP Wet Chemistry \& Laser Ablation Testing”, CCN 091850, August 2004.

[3] C.J. Coleman, "Alkali Fusion Dissolutions of Sludge and Glass for Elemental Analysis," ADS Procedure-2502, Rev.5, Nov. 1, 2002.

[4] C.J. Coleman, W.A. Spencer, "Cesium Hydroxide Fusion Dissolution of Analytical Reference Glass-1 in both Powder and Shard Form," WSRC-TR-98-00124, April 21, 1998.

[5] H.L. Anastos, S.A. Catlow, Hanford 222-S Laboratory Analytical Services Procedure-LA-549-141, Rev.Mod. G-3, July 19, 2001.

[6] C.J. Coleman, “Aqua Regia Dissolution of Sludge for Elemental Analysis,” ADS Procedure-2226, Rev. 6, February 25, 2003.

[7] C.J. Coleman, “Acid Dissolution of Glass and Sludge for Elemental Analysis,” ADS Procedure-2227, Rev. 7, May 10, 2002.

[8] C.J. Coleman, T.B. Edwards, D.R. Click, "SRNL Evaluation of Sub-sampling Precision and Accuracy of DWPF Slurry Mix Evaporator Simulant," WSCR-TR2004-00339, August 19, 2004.

[9] G.L. Smith, "Characterization of Analytical Reference Glass-1 (ARG-1),” PNL-8992, December, 2003.

[10] J.C. Hart, "Contained ICP-ES for Radioactive Samples JY170C,” ADS Procedure1564, September 30, 2003.

[11] C.J. Coleman, "Procedure for Measuring Wt. \% Total Solids, Soluble Solids, and Insoluble Solids," ADS Procedure-2284, Rev.0, May 5, 2003.

[12] T.B. Edwards, "Conventional Wet Chemistry ICP-AES Development for RPP-WTP AY-102/C-106 Sludge-Only Simulant - A Statistical Review of the Results from the Phase I Study," WSRC-TR-2005-00164 (SRNL-RPP-2005-00027), Revision 0, April, 2005.

[13] T.B. Edwards, "Conventional Wet Chemistry ICP-AES Development for RPP-WTP AZ-101 Sludge-Only Simulant - A Statistical Review of the Results from the Phase I Study," WSRC-TR-2005-00165 (SRNL-RPP-2005-00028), Revision 0, April, 2005. 
[14] T.B. Edwards, "Conventional Wet Chemistry ICP-AES Development for RPP-WTP AY-102/C-106 Melter Feed Slurry Simulants - A Statistical Review of the Results from the Phase I Study,” WSRC-TR-2005-00166 (SRNL-RPP-2005-00029), Revision 0, April, 2005.

[15] C.J. Coleman, M.S. Hay, K.B. Martin, "Compositing and Characterization of Samples from Hanford Tank 241-AY-102/C-106," WSRC-TR-2003-00205 (SRTRPP-2003-00086), October, 2003.

[16] DWPF Operating Procedure: SW4-15.201 Analytical Cells System Operating Manual Procedure 2.17 "Microwave Dissolution for Elemental Analysis." 